\title{
Heterometallic Modular Metal-Organic 3D Frameworks Assembled via New Tris- $\beta$-Diketonate Metalloligands: Nanoporous Materials for Anion Exchange and Scaffolding of Selected Anionic Guests.
}

\author{
Lucia Carlucci, ${ }^{*}$ Gianfranco Ciani, Simona Maggini, Davide M. Proserpio and Marco Visconti
}

\begin{abstract}
The modular engineering of heterometallic nanoporous metalorganic frameworks (MOFs) based on novel tris-chelate metalloligands, prepared using the functionalized $\beta$-diketone 1,3-bis(4'-cyano-phenyl)1,3-propanedione (HL), is here described. The complexes $\left[\mathrm{M}^{\mathrm{III}} \mathbf{L}_{3}\right][\mathrm{M}$ $=\mathrm{Fe}^{3+}$ and $\left.\mathrm{Co}^{3+}\right]$ and $\left[\mathrm{M}^{\mathrm{II}} \mathbf{L}_{3}\right]\left(\mathrm{NEt}_{4}\right)[\mathrm{M}$ $=\mathrm{Mn}^{2+}, \mathrm{Co}^{2+}, \mathrm{Zn}^{2+}$ and $\left.\mathrm{Cd}^{2+}\right]$ were synthesized and characterized, all exhibiting distorted octahedral chiral structure. The presence of six exooriented cyano donor groups on each complex makes it a suitable building block for networking via interactions with external metal ions. We have prepared two families of MOFs by reacting the metalloligands $\left[\mathrm{M}^{\mathrm{III}} \mathbf{L}_{3}\right]$ and $\left[\mathrm{M}^{\mathrm{II}} \mathbf{L}_{3}\right]^{-}$with many silver salts $\mathrm{AgX}(\mathrm{X}$ $=\mathrm{NO}_{3}^{-}, \mathrm{BF}_{4}^{-}, \mathrm{PF}_{6}^{-}, \mathrm{AsF}_{6}^{-}, \mathrm{SbF}_{6}^{-}$, $\mathrm{CF}_{3} \mathrm{SO}_{3}^{-}$, tosylate), namely the $\left[\mathrm{M}^{\mathrm{III}} \mathbf{L}_{3} \mathrm{Ag}_{3}\right] \mathrm{X}_{3} \cdot$ Solv and $\left[\mathrm{M}^{\mathrm{II}} \mathrm{L}_{3} \mathrm{Ag}_{3}\right] \mathrm{X}_{2} \cdot$ Solv network species.
\end{abstract}

Very interestingly all these networked species exhibit the same type of 3D structure and crystallize in the same trigonal space group with similar cell parameters, in spite of the different metal ions, ionic charges and $\mathrm{X}^{-}$silver counter-anions. We were also able to synthesize tri-metallic species like $\left[\mathrm{Zn}_{\mathrm{x}} \mathrm{Fe}_{\mathrm{y}} \mathrm{L}_{3} \mathrm{Ag}_{3}\right]\left(\mathrm{ClO}_{4}\right)_{(2 \mathrm{x}+3 \mathrm{y})} \cdot$ Solv and $\left[\mathrm{Zn}_{\mathrm{x}} \mathrm{Cd}_{\mathrm{y}} \mathrm{L}_{3} \mathrm{Ag}_{3}\right]\left(\mathrm{ClO}_{4}\right)_{2} \cdot \operatorname{Solv}$ (with $\mathrm{x}+\mathrm{y}$ $=1)$. All the frameworks can be described as 6-fold interpenetrated pcu nets, considering the $\mathrm{Ag}^{+}$ions as simple digonal spacers. Each individual net is homochiral, containing only $\Delta$ or $\Lambda$ nodes; the whole array contains three nets of type $\Delta$ and three nets of type $\Lambda$. Otherwise, taking into account the presence of weak $\sigma \mathrm{Ag}-\mathrm{C}$ bonds involving the central carbon atoms of the $\beta$-diketonato ligands of adjacent nets, the six interpenetrating pcu networks are joined into a unique non interpenetrated 6-connected frame with the rare acs topology. The networks contain large parallel channels of approximate hexagonal shape section that represent the $37-48 \%$ of the cell volume and include the anions and many guest solvent molecules. The guest solvent molecules can be reversibly removed by thermal activation with maintenance of the framework structure, that is stable up to ca. $270^{\circ} \mathrm{C}$, as confirmed by TGA and XRPD monitoring. The anions can be easily exchanged in single-crystal to single-crystal processes, that allow the insertion of selected anions in the framework channels.

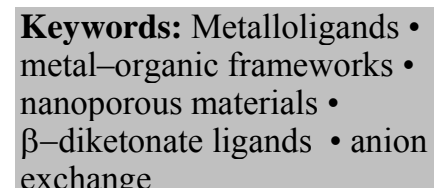
exchange

\section{Introduction}

Open metal-organic frameworks $(\mathrm{MOFs})^{[1,2]}$ are considered promising materials for many potential applications like gas storage, molecular sensing, separation, ion exchange, catalysis, optics, magnetism and others, ${ }^{[2]}$ and a great attention is currently focused on their design. An useful approach to the rational synthesis of such

[a] Dr. L. Carlucci, Prof. Dr. G. Ciani, Dr. S. Maggini, Prof. Dr. D.M. Proserpio, M. Visconti

Dipartimento di Chimica Strutturale e Stereochimica Inorganica

Università degli Studi di Milano

Via Venezian 21, 20133 Milano (Italy)

Fax: (+39) 0250314454

E-mail: lucia.carlucci@unimi.it

Supporting information for this article is available on the WWW under http://www.chemeurj.org/ or from the author. networked species consists in the use of molecular building blocks, usually metal-containing species called metalloligands ${ }^{[3-6]}$ that exhibit peripheral suitably oriented exo-donor groups and are therefore able to direct the formation of the polymeric array. The metalloligands are used in place of organic ligands to join different metal centers, thus possibly affording heterobimetallic architectures (including many $3 \mathrm{~d}-4 \mathrm{f}$ systems) ${ }^{[4]}$ with additional properties; at difference from the SBUs that can be envisaged as fundamental constituent units in the networks assembled via the reticular chemistry approach ${ }^{[1 \mathrm{~b}, \mathrm{c}, 7]}$ the metalloligands are self-existing entities. This stepwise approach implies, at first, the careful selection of the polyfunctional ligands to be employed in the preparation of the discrete metal-organic building blocks with the desired geometry. Chelating ligands are the most frequently used, that generate bis- or tris-chelated complexes and bear additional outword directed donor groups (mainly carboxylate, nitrile or pyridyl). For instance, tris(dipyrrinato) metal complexes ${ }^{[5]}$ were shown to be a versatile class of metalloligands for the preparation of a variety of interesting MOF structures. Also few functionalised $\beta$-diketonate ligands were employed as suitable chelating agents for the preparation of 
metalloligands; the known examples include tris-chelated complexes with 3-substituted acetylacetonates (having pyridyl or $\mathrm{CN}$ substituent groups $)^{[6 a, b]}$ and the bis-chelated species $\left[\mathrm{Cu}(\mathrm{pyac})_{2}\right]$ [pyac $=3$-(4-pyridyl)pentane-2,4-dionato]. ${ }^{[6 \mathrm{c}, \mathrm{d}]}$

We report here an approach for the modular engineering of heterometallic MOFs based on the use of a functionalized $\beta$ diketone, namely 1,3-bis(4'-cyano-phenyl)-1,3-propanedione (HL).<smiles>N#CC(=CC(=O)c1ccc(C#N)cc1)c1ccc(C#N)cc1</smiles>

Scheme 1. 1,3-bis(4'-cyano-phenyl)-1,3-propanedionato ( $\left.\mathbf{L}^{-}\right)$.

The corresponding $\beta$-diketonate ligand $\left(\mathbf{L}^{-}\right.$, see Scheme 1$)$, besides to act as chelating agent on a metal center, can donate with the two $\mathrm{CN}$ groups to other metals, and potentially can also give interactions with metals using its central carbon atom. This ligand has been employed by us to prepare novel tris-chelate neutral complexes of metal trications $\left[\mathrm{ML}_{3}\right][\mathrm{M}=\mathrm{Co}(\mathrm{III}), \mathrm{Fe}(\mathrm{III})]$ and trischelate anionic complexes of metal dications $\left[\mathrm{ML}_{3}\right]^{-}[\mathrm{M}=\mathrm{Mn}(\mathrm{II})$, $\mathrm{Co}(\mathrm{II}), \mathrm{Zn}(\mathrm{II}), \mathrm{Cd}(\mathrm{II})]$. These are the discrete metal-organic building blocks used in the construction of heterometallic MOFs by reaction with a number of $\mathrm{AgX}$ silver salts $\left(\mathrm{X}=\mathrm{NO}_{3}{ }^{-}, \mathrm{BF}_{4}^{-}, \mathrm{PF}_{6}^{-}, \mathrm{AsF}_{6}{ }^{-}\right.$, $\mathrm{SbF}_{6}^{-}, \mathrm{CF}_{3} \mathrm{SO}_{3}^{-}$, tosylate). We have thus obtained a numerous family of 3D nanoporous networks in crystalline form, with composition $\left[\mathrm{M}^{\mathrm{III}} \mathbf{L}_{3} \mathrm{Ag}_{3}\right] \mathrm{X}_{3}$. Solv and $\left[\mathrm{M}^{\mathrm{II}} \mathbf{L}_{3} \mathrm{Ag}_{3}\right] \mathrm{X}_{2}$. Solv, that have been structurally characterized. Surprisingly all these networks exhibit very similar structure, thus indicating a great efficiency of the metalloligands together with the $\mathrm{Ag}^{+}$spacers in orienting the outcoming polymeric architecture. The results of our investigations on the network porosity and on the anion-exchange ability of these materials, containing large 1D parallel channels that allow the insertion of interesting anionic species, are also reported.

\section{Results and Discussion}

Stepwise modular synthesis: We started with the project of the synthesis of a new tris-chelate metalloligand, bearing six exooriented donor groups, as building block for heterometallic networks. For this purpose we have selected as ligand a symmetrically disubstituted $\beta$-diketonate anion, considering the successful use of such species in the preparation of metalloligands. ${ }^{[6]}$ We have synthesized the 1,3-bis(4'-cyanophenyl)-1,3-propanedione (HL) molecule, never employed before in the context of metal coordination polymers (but in the preparation of some palladium complexes with liquid crystal properties) ${ }^{[8]}$. It was prepared following a literature method, ${ }^{[9]}$ using a base-catalysed condensation between 4-acetylbenzonitrile and methyl-4cyanobenzoate.

Single crystals of $\mathbf{H L}$ were obtained and investigated by X-ray diffraction. The crystal structure is comprised of flat molecules in the enol form, with intramolecular H-bonding (see Figure S1 and Table S1 in the Supporting Information).

The corresponding $\beta$-diketonate ligand $\left(\mathbf{L}^{-}\right)$can work both as a chelating agent on a metal center and as a donor towards other external metals with the two exo-directed cyano groups; moreover, at the same time, it can potentially also interact outwards with other metal atoms via the central carbon atom of the $\beta$-diketonate, as already observed in many dinuclear and oligonuclear complex species. ${ }^{[10]}$ The $\mathbf{L}^{-}$anion has been then reacted with the metal ions to obtain the tris-chelate metalloligands.

The metalloligands: Deprotonation of $\mathbf{H L}$ with $\left(\mathrm{NEt}_{4}\right) \mathrm{OH}$ in ethanol or water affords solutions of the salt $\left(\mathrm{NEt}_{4}\right) \mathbf{L}$, that is reacted with $\mathrm{M}^{3+}$ or $\mathrm{M}^{2+}$ metal ions. Bulk polycrystalline products have been obtained for the tris-chelate complexes of both trications, $\left[\mathrm{M}^{\mathrm{III}} \mathbf{L}_{3}\right]$ $\left[\mathrm{M}=\mathrm{Fe}^{3+}(\mathbf{1 a})\right.$ and $\left.\mathrm{Co}^{3+}(\mathbf{1 b})\right]$, and dications, $\left[\mathrm{M}^{\mathrm{II}} \mathbf{L}_{3}\right]\left(\mathrm{NEt}_{4}\right)[\mathrm{M}=$ $\mathrm{Mn}^{2+}(\mathbf{2 a}), \mathrm{Co}^{2+}(\mathbf{2 b}), \mathrm{Zn}^{2+}(\mathbf{2 c})$ and $\left.\mathrm{Cd}^{2+}(\mathbf{2 d})\right]$. The metalloligands were characterized by IR, ${ }^{1} \mathrm{H}$ NMR, XRPD, TGA and selected magnetic measurements. Attempts to obtain the $\mathrm{Fe}^{2+}$ species failed, very probably due to partial oxidation of the metal ions in the reaction conditions.
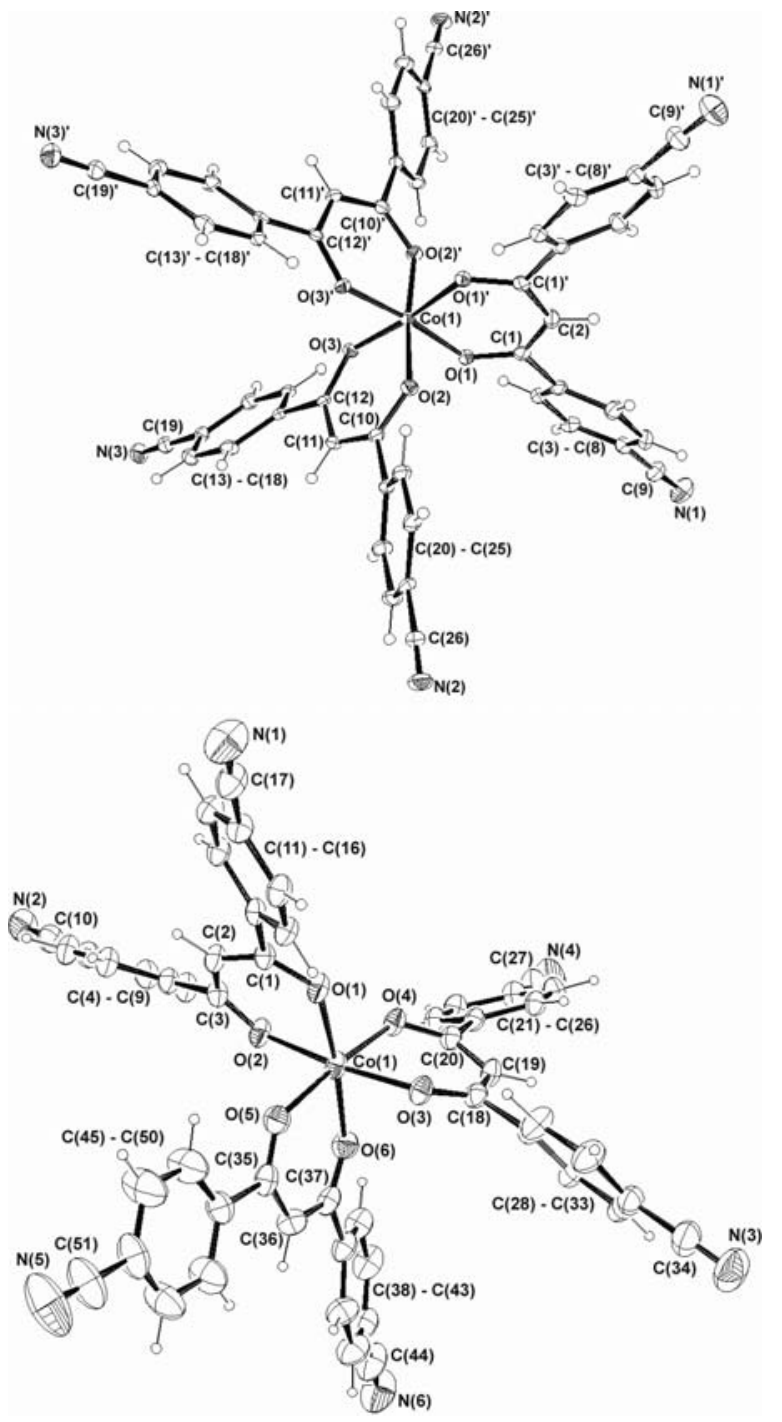

Figure 1. ORTEP drawings of the metalloligands $\Delta-\left[\mathrm{Co}^{\mathrm{III}} \mathbf{L}_{3}\right]$ (1b) (top) and $\Lambda-\left[\mathrm{Co}^{\mathrm{II}} \mathbf{L}_{3}\right]^{-}$ (2b) (bottom). The data collection were performed respectively at $150 \mathrm{~K}$ and $293 \mathrm{~K}$. Thermal ellipsoids are drawn at the $30 \%$ probability level.

In order to fully characterize these species we have attempted to growth single crystals from the crude materials using slow diffusion methods. For the neutral species $\left[\mathrm{M}^{\mathrm{III}} \mathbf{L}_{3}\right]$ this was a difficult task since crystallization is much dependent on the solvent system, producing only polycrystalline samples that exhibit variated XRPD patterns. In the case of $\left[\mathrm{FeL}_{3}\right]$ a crystalline product is obtained in methanol that, however, corresponds to the dinuclear $\mathrm{Fe}^{\mathrm{III}}$ species $\left[\mathrm{FeL}_{2}(\mu-\mathrm{OMe})\right]_{2}$ (as evidenced by a single crystal X-ray analysis, see Fig. S2 in the Supporting Information). We have serendipitously 
isolated single crystals of the acetone solvated species $\left[\mathrm{CoL}_{3}\right](\mathbf{1 b})$, whose crystal structure is here reported. On the other hand we have been able to obtain in good yields single crystals for all the $\left[\mathrm{M}^{\mathrm{II}} \mathbf{L}_{3}\right]\left(\mathrm{NEt}_{4}\right)$ metalloligands (2a-2d), that exhibit very similar triclinic unit cells (see Table S1 in the Supporting Information) in spite of the presence of different guest solvent molecules.

The crystal structure of $\mathbf{1 b} \cdot 3$ (acetone) consists of the packing of discrete neutral $\left[\mathrm{CoL}_{3}\right]$ molecules illustrated in Fig. 1 (top). It can be compared with the structure of the THF solvated metalloligand $\mathbf{2 b}$, $\left[\mathrm{CoL}_{3}\right]\left(\mathrm{NEt}_{4}\right) \cdot \mathrm{THF}$, taken as representative of the anionic trischelate species (Fig. 1, bottom).

All these metalloligands exhibit distorted octahedral chiral structure (of ideal $D_{3}$ symmetry, see selected bond parameters in Table S2 in the Supporting Information) that are packed in centrosymmetric space groups, thus resulting in the balance of the $\Delta$ and $\Lambda$ enantiomeric forms. On comparing the $\mathrm{MO}_{6}$ coordination geometries we observe that the $\mathrm{M}-\mathrm{O}$ bond lengths show the expected trends, i.e. longer bonds, on passing from the first to the second transition row [eg. $\mathrm{Zn}^{2+}$ vs. $\mathrm{Cd}^{2+}$ 2.054(2)-2.118(2) $\AA$ vs. $2.242(2)-2.278(2) \AA]$ and shorter bonds with increased metal charge [eg. $\mathrm{Co}^{2+}$ vs. $\mathrm{Co}^{3+}$ 2.047(3)-2.088(3) $\AA$ vs.1.884(3)-1.893(3) $\left.\AA\right]$.

The orientations of the six cyano donor groups in each metalloligand are approximately those required for a 6-connected octahedral node in the networking process [for instance the $\mathrm{M} \cdots \mathrm{N}$ distances and $\mathrm{N} \cdots \mathrm{M} \cdots \mathrm{N}$ angles for $\mathbf{1 b}$ are in the ranges 9.316(5)-9.374(6) $\AA, \quad 86.04(4)-98.18(4)^{\circ}$ (cisoid angles) and 173.43(4)-173.85(4) ${ }^{\circ}$ (transoid angles); on the other hand for $\mathbf{2 b}$ the corresponding interactions span the intervals 9.424(7)-9.550(5) $\AA$, 67.50(6)-127.21(6) ${ }^{\circ}$ (cisoid angles) and 163.94(6)-172.14(5) ${ }^{\circ}$ (transoid angles), with much larger deviations from the ideal angular values]. We have also prepared and structurally characterized crystals of the $\mathrm{Cd}^{2+}$ metalloligand with a quite different counter-cation, namely the salt $\left[\mathrm{CdL}_{3}\right](\mathrm{PPN})[\mathrm{PPN}=$ bis(triphenylphosphine)iminium] (2d') (see Tables S1 and S2 in the Supporting Information) in order to ascertain a possible templating role of the cation in the successive step of self-assembly of the 3D heterometallic networks (see below).

The heterometallic MOFs: The reactions of the metalloligands, both the $\mathrm{M}^{\mathrm{III}}$ and the $\mathrm{M}^{\mathrm{II}}$ containing complexes, in proper solvents with many different $\mathrm{AgX}$ salts afforded crystalline products of the $\left[\mathrm{M}^{\mathrm{III}} \mathbf{L}_{3} \mathrm{Ag}_{3}\right] \mathrm{X}_{3}$.Solv (3) and $\left[\mathrm{M}^{\mathrm{II}} \mathbf{L}_{3} \mathrm{Ag}_{3}\right] \mathrm{X}_{2} \cdot \operatorname{Solv}$ (4) networked species, respectively, most of which are suitable for single crystal $\mathrm{X}$-ray analysis, though the crystallographic data are in some cases of poor quality due to heavy disorder of the guest solvent molecules and of the counter-anions $\mathrm{X}^{-}$, that populate the large network channels (see below).

Within the family $\left[\mathrm{M}^{\mathrm{III}} \mathbf{L}_{3} \mathrm{Ag}_{3}\right] \mathrm{X}_{3} \cdot \operatorname{Solv}$ (3) we have investigated crystals of the species $3 \mathbf{a}\left(\mathrm{M}=\mathrm{Fe}^{3+} ; \mathrm{X}^{-}=\mathrm{CF}_{3} \mathrm{SO}_{3}{ }^{-}\right), \mathbf{3 b}\left(\mathrm{M}=\mathrm{Fe}^{3+}\right.$; $\left.\mathrm{X}^{-}=\mathrm{PF}_{6}^{-}\right), 3 \mathbf{c}\left(\mathrm{M}=\mathrm{Fe}^{3+} ; \mathrm{X}^{-}=\mathrm{BF}_{4}^{-}\right), 3 \mathbf{d}\left(\mathrm{M}=\mathrm{Fe}^{3+} ; \mathrm{X}^{-}=\mathrm{ClO}_{4}^{-}\right), 3 \mathbf{e}$ $\left(\mathrm{M}=\mathrm{Co}^{3+} ; \mathrm{X}^{-}=\mathrm{SbF}_{6}^{-}\right), 3 \mathbf{f}\left(\mathrm{M}=\mathrm{Co}^{3+} ; \mathrm{X}^{-}=\mathrm{CF}_{3} \mathrm{SO}_{3}^{-}\right), 3 \mathbf{g}(\mathrm{M}=$ $\left.\mathrm{Co}^{3+} ; \mathrm{X}^{-}=\mathrm{BF}_{4}^{-}\right)$, but only the structures of $\mathbf{3 a}$ and $\mathbf{3 b}$ are here reported in full detail. The structure of $3 \mathbf{a}$ has been selected as representative of this family of networks.

A more rich series of members of the family $\left[\mathrm{M}^{\mathrm{II}} \mathbf{L}_{3} \mathrm{Ag}_{3}\right] \mathrm{X}_{2} \cdot \mathrm{Solv}$ (4) was isolated as single crystals, that include: $4 \mathbf{a}\left(\mathrm{M}=\mathrm{Mn}^{2+} ; \mathrm{X}^{-}=\right.$ $\left.\mathrm{BF}_{4}^{-}\right), \mathbf{4 b}\left(\mathrm{M}=\mathrm{Zn}^{2+} ; \mathrm{X}^{-}=\mathrm{BF}_{4}^{-}\right), 4 \mathbf{c}\left(\mathrm{M}=\mathrm{Zn}^{2+} ; \mathrm{X}^{-}=\mathrm{ClO}_{4}^{-}\right), \mathbf{4 d}(\mathrm{M}$ $\left.=\mathrm{Zn}^{2+} ; \mathrm{X}^{-}=\mathrm{CF}_{3} \mathrm{SO}_{3}^{-}\right), 4 \mathbf{e}\left(\mathrm{M}=\mathrm{Zn}^{2+} ; \mathrm{X}^{-}=\mathrm{PF}_{6}^{-}\right), \mathbf{4 f}\left(\mathrm{M}=\mathrm{Zn}^{2+} ; \mathrm{X}^{-}\right.$ $\left.=\mathrm{AsF}_{6}^{-}\right), \mathbf{4 g}\left(\mathrm{M}=\mathrm{Zn}^{2+} ; \mathrm{X}^{-}=\mathrm{SbF}_{6}^{-}\right), \mathbf{4 h}\left(\mathrm{M}=\mathrm{Zn}^{2+} ; \mathrm{X}^{-}=\mathrm{NO}_{3}^{-}\right), \mathbf{4 i}$ $\left(\mathrm{M}=\mathrm{Zn}^{2+} ; \mathrm{X}^{-}=\right.$tosylate $), \mathbf{4 j}\left(\mathrm{M}=\mathrm{Cd}^{2+} ; \mathrm{X}^{-}=\mathrm{ClO}_{4}^{-}\right), \mathbf{4 k}\left(\mathrm{M}=\mathrm{Cd}^{2+}\right.$; $\left.\mathrm{X}^{-}=\mathrm{BF}_{4}^{-}\right)$. The structures of $\mathbf{4 b}, \mathbf{4} \mathbf{c}, \mathbf{4 e}, \mathbf{4 i}, \mathbf{4 j}$ and $\mathbf{4 k}$ have been fully refined, while for the remainder we have determined only the cell parameters. The structure of $\mathbf{4 c}$ can be selected as representative of family 4 .

Attempts to react the $\mathrm{Co}^{2+}$ metalloligand (2b) with different silver salts have not produced crystals of the corresponding network species because of cobalt oxidation under the reaction conditions employed, accompanied by $\mathrm{Ag}^{+}$reduction to metal as evidenced by the silver mirror on the walls of the reaction vessel.

All the crystals of the families $\mathbf{3}$ and $\mathbf{4}$ belong to the Trigonal system, Space Group P-3 (No. 147), with close unit cell parameters (see Table 1, and Tables S3 and Table S5 in the Supporting Information) and their structures contain a very similar complex $3 \mathrm{D}$ network, based on the $\mathrm{ML}_{3}$ metalloligands as 6-connected nodes, since they use all their six exo-oriented cyano functionalities to bind six $\mathrm{Ag}^{+}$ions.

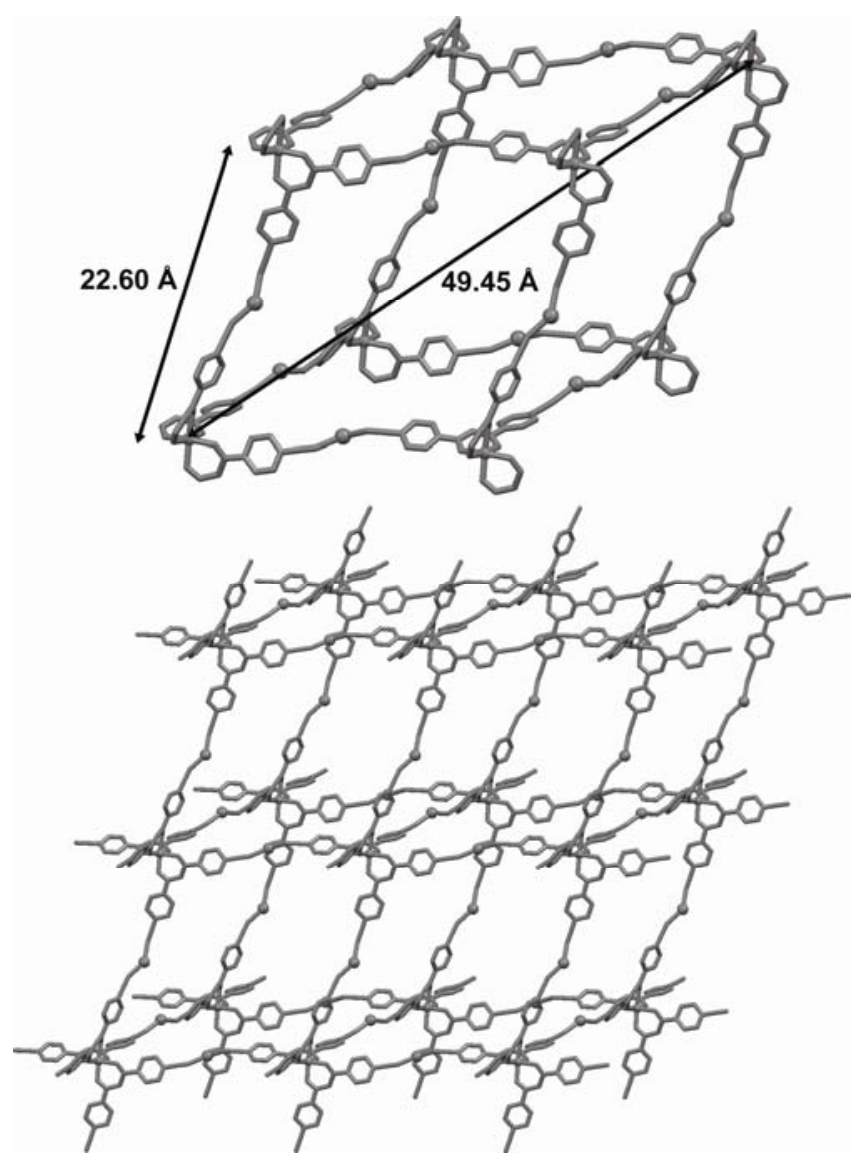

Figure 2.View of a single 'cubic' cage (top) and of the pcu network (bottom) in 4c.

The nearly octahedral geometry and the bond parameters of the free metalloligands are essentially retained in the nodes of the networks with only some minor changes (see Table S4), with values in accord with the trends above mentioned. The metal ions lie on three-fold crystallographic axes and the $\mathrm{M}-\mathrm{O}$ bond lengths are in the ranges 1.980(4)-1.998(4) $\AA$ for $\mathrm{Fe}^{\mathrm{III}}, 2.037(3)-2.084(3) \AA$ for $\mathrm{Zn}^{\mathrm{II}}$ and 2.225(8)-2.268(4) $\AA$ for $\mathrm{Cd}^{\mathrm{II}}$.

The silver ions can be considered as digonal spacers that link the metal complexes to generate a 3D network, which exhibits the pcu (point symbol $4^{12} \cdot 6^{3}$ ) topology (see Figure 2, relative to compound 4c). The 'cubic' cages are strongly distorted towards rhombohedral shape because of a stretching along one of the body diagonals, i.e. that aligned in the direction of the $c$ crystallographic axis, whose value is equal to $3 \times c$ (long body diagonal $49.45 \AA$ vs. short diagonals $35.03 \AA$ in $4 c$ ). The edges of the cages in the families 3 
and 4 have values in the range $22.46-22.97 \AA$; the cage $\mathrm{M} \cdots \mathrm{M} \cdots \mathrm{M}$ acute angles span the interval $68.64-74.08^{\circ}$ (see Table 1).
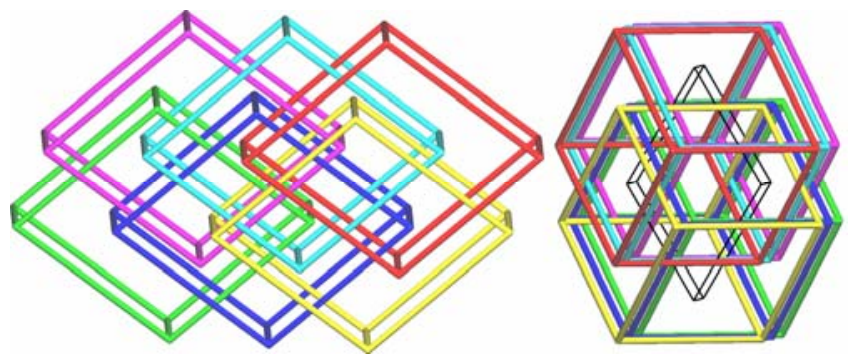

Figure 3. Two schematic view of the 6-fold interpenetrated pcu networks showing that the 6 nets are grouped by $3+3$, with the 3 nets in each set related by translation: Class IIIa $[Z=6(3 * 2)]$.

The networks are 6-fold interpenetrated (see Figure 3) and each individual net is homochiral, comprised of exclusively $\Delta$ or $\Lambda$ trischelate metal nodes. The whole array contains a group of three nets of type $\Delta$ and an enantiomeric group of three nets of type $\Lambda$; within each group the three nets are related by pure translation (translational vector [100] and its symmetry equivalents) while the two groups are in centrosymmetric relationship $(3 \Delta+3 \Lambda)$, as shown in Figure 4. This type of interpenetration is classified as belonging to Class IIIa $[\mathrm{Z}=6(3 * 2)]$ were both translational and nontranslational symmetry operations correlate the six nets. ${ }^{[11]}$

These networks represent the first example of 6-fold interpenetration for pcu topology, the actual world record for this topology. Previous examples of highly interpenetrating pcu nets comprised only two cases of 4 -fold ${ }^{[12]}$ and two cases of 5-fold interpenetration. $^{[13]}$

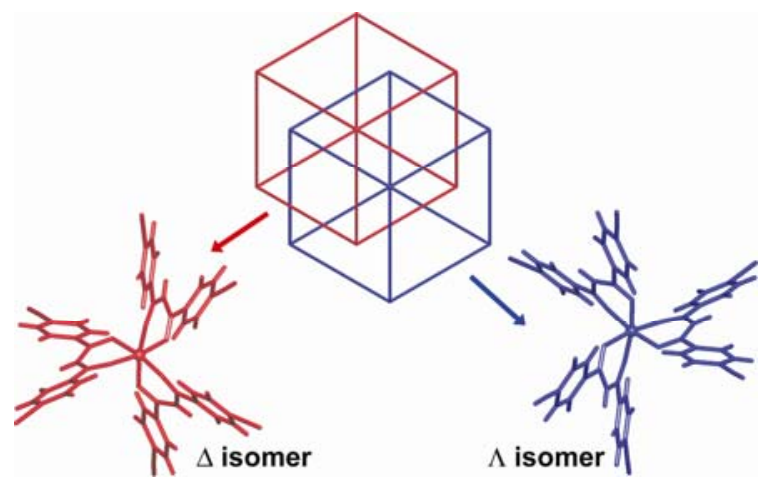

Figure 4. Schematic view down the $c$ axis of the 6-fold interpenetration, evidencing the two centrosymmetrically related homochiral groups $(3 \Delta+3 \Lambda)$.

A more strict analysis of the differences within the network structures of the families $\mathbf{3}$ and $\mathbf{4}$ reveals a very interesting feature. In all the networks formed by the anionic metalloligands, $\left[\mathrm{M}^{\mathrm{II}} \mathrm{L}_{3} \mathrm{Ag}_{3}\right] \mathrm{X}_{2} \cdot$ Solv (4), the silver spacers significantly interact with the central carbon atoms of the $\beta$-diketonate ligands chelating the metal nodes of adjacent nets. All the silver atoms and all the $\beta$ diketone ligands are involved in these weak $\sigma \mathrm{Ag}-\mathrm{C}$ bonds [in the range 2.451(11) - 2.531(7) $\AA$, see Figure 5 and Table 1]. Similar relatively weak bonds between $\mathrm{Ag}$ and the methine $\mathrm{C}$ atom were previously observed in many $\beta$-diketonato oligomeric complexes, ${ }^{[14]}$ which, however, exhibit shorter Ag-C contacts, down to ca. $2.24 \AA$ in the anion $\left[\mathrm{Pd}_{2} \mathrm{Ag}(\mathrm{acac})_{2}\left(\mathrm{C}_{6} \mathrm{~F}_{5}\right)_{4}\right]^{-\left[{ }^{[14 b]}\right.}$ On the other hand, in the networks deriving from the neutral metalloligands, $\left[\mathrm{M}^{\mathrm{III}} \mathrm{L}_{3} \mathrm{Ag}_{3}\right] \mathrm{X}_{3} \cdot$ Solv (3), these $\mathrm{Ag} \cdots \mathrm{C}$ interactions are either markedly weaker [i.e. 2.827(7) $\AA$ in 3a] or not existing at all [i.e. shortest $\mathrm{Ag} \cdots \mathrm{C}$ (methine) contact of 3.831(7) $\AA$ in $3 \mathbf{b}]$, probably due to the lack of the negative charge on the metal complexes.

The coordination of the $\mathrm{Ag}$ atoms $[\mathrm{Ag}-\mathrm{N}$ bonds in the range 2.114(7)-2.217(7) $\AA$ ] generally shows marked deviations from linearity [with $\mathrm{N}-\mathrm{Ag}-\mathrm{N}$ angles in the interval 140.8(2)-154.3(3) ${ }^{\circ}$ ]. The bending is very probably due to the weak $\mathrm{Ag} \cdots \mathrm{C}$ and/or $\mathrm{Ag} \cdots$ anion interactions, and this can introduce a certain flexibility of the frames.

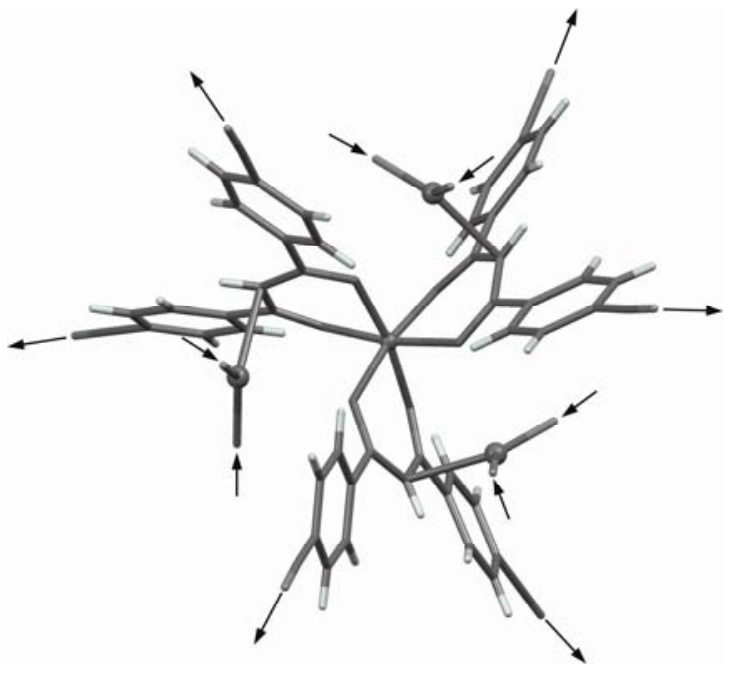

Figure 5. Interactions of the metalloligand node with three $\mathrm{Ag}$ atoms of three adjacent nets. This $\left[\mathrm{ML}_{3} \mathrm{Ag}_{3}\right]$ moiety is a novel SBU that presents six donor cyano groups and six acceptor sites on the silver atoms (see arrows).

Each chiral node $(\Delta$ or $\Lambda)$ interacts with three silver atoms belonging to three adjacent pcu nets of opposite chirality. Tacking into account these additional interactions the six interpenetrating pcu nets are bundled up into a unique non interpenetrated 6connected network with the rare acs topology. ${ }^{[15,11 b]}$ The $\left[\mathrm{ML}_{3} \mathrm{Ag}_{3}\right]$ moiety can be considered as a novel six-connected SBU (see Fig. 5) that generates the whole $3 \mathrm{D}$ network (schematically illustrated in Fig. 6), which exhibits trigonal prismatic nodes, with all the edges that are double (see Fig. 7) and with $\mathrm{M} \cdots \mathrm{M}$ contacts that are about one-half the length of the edges in the pcu networks. The $\left[\mathrm{ML}_{3} \mathrm{Ag}_{3}\right]$ SBU uses all the six cyano donor groups and the three Ag atoms (each accepting two external $\mathrm{CN}$ ) to form the single network. These twelve interactions of the SBU (6 as donor and 6 as acceptor) originate the double-edged single acs net. It can also be remarked that the chirality of each node of the net is opposite to that of the six nodes connected to it.

Within the double edges (illustrated in Fig. 7) weak $\pi-\pi$ interactions are observed involving the phenyl rings of different diketonate ligands. Geometrical data for the prismatic nodes are reported in Table 1.

The acs topology [point symbol $\left(4^{9} .6^{6}\right)$ ] applies to a network formed by linking trigonal prisms, as observed in the tungsten carbide WC. ${ }^{[15]}$ It is an uninodal edge-transitive net (one kind of node and one kind of edge). Some examples of acs networks in coordination polymers have been previously characterized. ${ }^{[15 b, 16]}$

The more interesting feature of these species (families $\mathbf{3}$ and 4) is the fact that only one network structure type is always obtained, in spite of the different metal ions, their ionic charges and the nature of 
Table 1: Comparison of the crystallographic data and the network parameters (in the pcu and acs topologies) for the refined MOFs

\begin{tabular}{|c|c|c|c|c|c|c|c|c|c|c|c|c|}
\hline \multicolumn{6}{|c|}{ crystal data } & \multicolumn{4}{|c|}{ pcu topology } & \multicolumn{3}{|c|}{ acs topology } \\
\hline $3 a$ & $15.217(1)$ & $16.738(2)$ & 1.100 & $3356.4(5)$ & 43.9 & 22.621 & 50.214 & 34.733 & 71.26 & $\begin{array}{l}13.787 \\
10.703 \\
\end{array}$ & 15.217 & 2.827 \\
\hline 4b & $15.733(3)$ & $16.486(6)$ & 1.048 & $3534(2)$ & 47.3 & 22.788 & 49.458 & 35.523 & 73.44 & $\begin{array}{l}14.005 \\
10.791\end{array}$ & 15.733 & 2.474 \\
\hline $4 c$ & $15.457(1)$ & $16.483(3)$ & 1.066 & $3410.5(7)$ & 44.9 & 22.597 & 49.449 & 35.034 & 72.65 & $\begin{array}{l}13.916 \\
10.646\end{array}$ & 15.457 & 2.468 \\
\hline $4 \mathbf{i}$ & $15.649(6)$ & $16.472(8)$ & 1.053 & $3493(2)$ & 47.5 & 22.720 & 49.416 & 35.368 & 73.24 & $\begin{array}{l}13.973 \\
10.743\end{array}$ & 15.649 & 2.451 \\
\hline $4 \mathrm{j}$ & $15.824(3)$ & $16.563(6)$ & 1.047 & $3592(2)$ & 47.4 & 22.970 & 49.689 & 35.720 & 73.49 & $\begin{array}{l}14.075 \\
10.852\end{array}$ & 15.824 & 2.531 \\
\hline $4 k$ & $15.939(2)$ & $16.463(5)$ & 1.033 & $3622(1)$ & 47.8 & 22.915 & 49.389 & 35.878 & 74.08 & $\begin{array}{l}14.137 \\
10.841\end{array}$ & 15.939 & 2.515 \\
\hline
\end{tabular}

(a): Values computed with the program Platon after removing the clathrate solvent and anion molecules. (b): M is refererred to the central metal atom of the corresponding SBU. (c): $\mathrm{d} 1$, d2 and $\mathrm{d} 3$ represent the $\mathrm{M} \cdots \mathrm{M}$ distances between the central metal atoms of adjacent SBUs. 
the $\mathrm{X}^{-}$silver counter-anions, thus indicating a great efficiency of the selected metalloligands together with the Ag spacers in orienting the outcoming polymeric architecture. This target topology is strictly determined by the rigid geometry of the molecular building blocks. Thus it can be anticipated that other members of the families $\mathbf{3}$ and $\mathbf{4}$ could be obtained by changing the $\mathrm{M}^{\mathrm{III}}$ or $\mathrm{M}^{\mathrm{II}}$ metals.

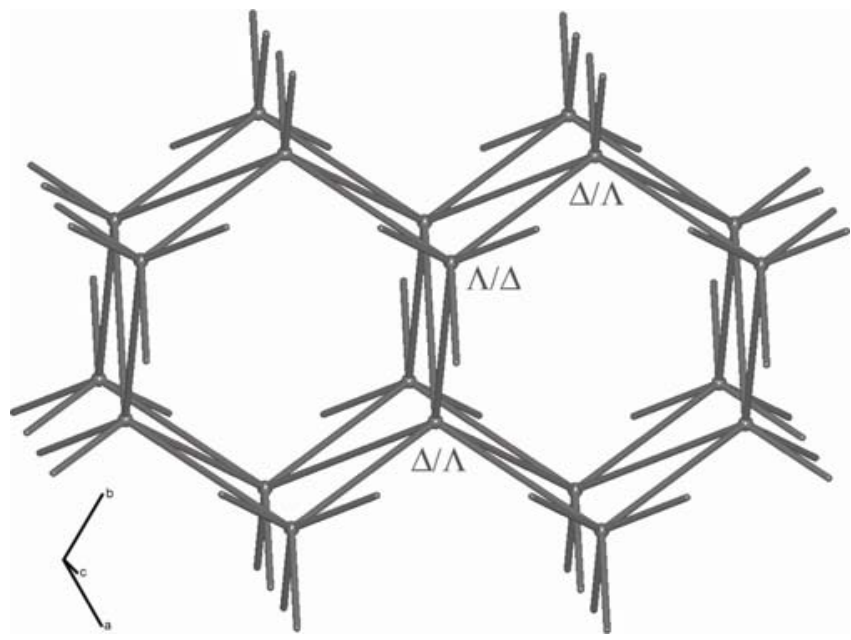

Figure 6. The schematized 6-connected acs network; the alternation of $\Delta$ and $\Lambda$ nodes is evidenced.

To confirm this exceptional network preference we have carried out other experiments. We have investigated on a possible role of the counter-cation of the anionic metalloligands in driving the formation of the MOFs. After the preparation and the single crystal $\mathrm{X}$-ray characterization of the species $\left[\mathrm{CdL}_{3}\right](\mathrm{PPN})[\mathrm{PPN}=$ bis(triphenylphosphine)iminium] (2d', see Table $\mathrm{S} 1$ in the Supporting Information), containing a bulky cation, we have reacted it with $\mathrm{AgClO}_{4}$ in the same conditions previously used for networking, obtaining the species $\left[\mathrm{CdL}_{3} \mathrm{Ag}_{3}\right]\left(\mathrm{ClO}_{4}\right)_{2} \cdot \operatorname{Solv}(\mathbf{4 j}$ ') that results isostructural with $\mathbf{4 j}$. Again we observe that the change of a factor that could have had a drastic effect on the resulting framework is not effective within these species.

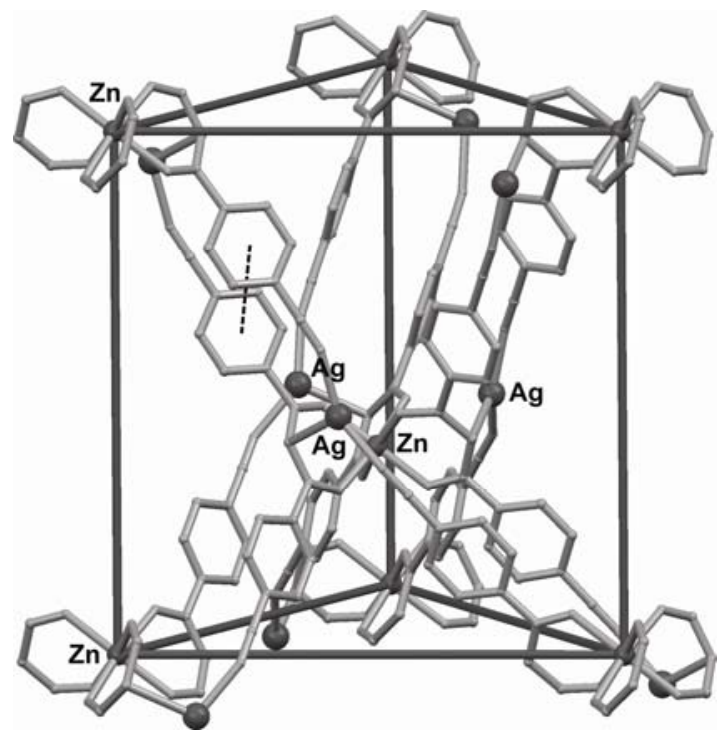

Figure7. The trigonal prismatic environment of each node in $4 \mathbf{c}$, representative of the family 4 , that shows the double-edges with $\pi-\pi$ interactions. The three upper edges are longer $(\mathrm{Zn} \cdots \mathrm{Zn} 13.916 \AA)$ than the three lower ones $(\mathrm{Zn} \cdots \mathrm{Zn} 10.646 \AA)$. A dotted line shows one of the $\pi-\pi$ interactions involving the phenyl rings (for $4 \mathrm{c}$ : $0^{\circ} / 3.57 \AA / 1.66 \AA$ / angle/distance/offset between phenyl rings).
It was therefore reasonable to suspect also the possibility to obtain analogous MOFs containing mixed network nodes by using in the same reaction different metalloligands. We have synthesized the tri-metallic species $\left[\mathrm{Zn}_{\mathrm{x}} \mathrm{Fe}_{\mathrm{y}} \mathrm{L}_{3} \mathrm{Ag}_{3}\right]\left(\mathrm{ClO}_{4}\right)_{(2 \mathrm{x}+3 \mathrm{y})} \cdot \mathrm{Solv}$ (5a) and $\left[\mathrm{Zn}_{\mathrm{x}} \mathrm{Cd}_{\mathrm{y}} \mathbf{L}_{3} \mathrm{Ag}_{3}\right]\left(\mathrm{ClO}_{4}\right)_{2} \cdot$ Solv (5b), (both with $\mathrm{x}+\mathrm{y}=1$ ). By means of SEM equipped for elemental analyses we have confirmed in both cases the presence of the three metals approximately in the correct ratios. The two compounds display crystal cell parameters similar to those found for families $\mathbf{3}$ and $\mathbf{4}$ within the same space group. The structure of $\mathbf{5 b}$ has been successfully refined with a statistical distribution of the $\mathrm{Zn}$ and $\mathrm{Cd}$ atoms on the network nodes (i.e. $\mathrm{x}=\mathrm{y}$ $=0.5$, see Table $\mathrm{S} 3$ in the Supporting Information). The $\mathrm{M}-\mathrm{O}$ bond lengths $[2.111(4)-2.160(4) \AA]$ are intermediate between the $\mathrm{Zn}-\mathrm{O}$ $[2.037(3)-2.084(4) \AA]$ and the $\mathrm{Cd}-\mathrm{O}[(2.225(8)-2.268(4) \AA]$ bond length values observed in the $\mathrm{Zn}^{\mathrm{II}}$ and $\mathrm{Cd}^{\mathrm{II}}$ networks of family 4 .

Channel structure and nanoporous behaviour: At difference from the well established structural features of the networks the content of the large intraframework void spaces is much less easily understood due to marked disorder of the included species, as it is usual in nanoporous networked polymers. Indeed, these void regions represent a large part of the cell volume and are mainly localized in large parallel channels of almost hexagonal shape section, all running along the $c$ axis direction (see Figure 8). They contain the anions (often disordered and in some cases weakly interacting with the $\mathrm{Ag}^{+}$ions) as well as the chlatrate solvent molecules (mixtures of solvents), that are generally disordered. Though the data collections were performed at $\mathrm{T}=150 \mathrm{~K}$ these molecules cannot be located from the $\mathrm{X}$-ray crystallographic data. A single channel of $\mathbf{4 c}$ is illustrated in Figure 9.

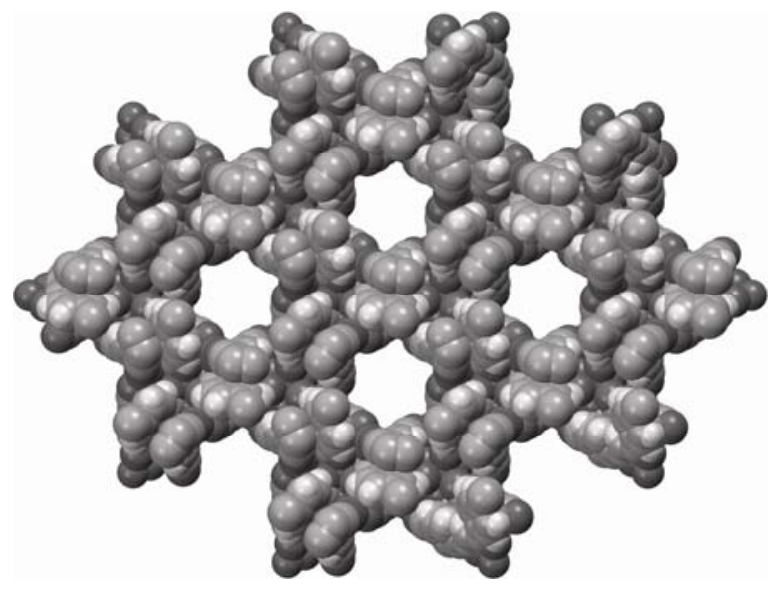

Figure 8. View of the packing down the $\boldsymbol{c}$ axis in $\mathbf{4 c}$ showing the channels of approximate hexagonal section.

The dimensions of the channels are determined by the mutual positions of the SBUs: as in the prototypical structure of WC, with the acs topology, the channels are columns of stacked trigonal antiprismatic cages (as schematized in Fig. 10).

The $\mathrm{M} \cdots \mathrm{M}$ edges are reported in Table 1 , giving the values of the $d_{1}, d_{2}$ and $d_{3}$ edges (shown in Fig. 10). The comparison shows that the networks are rather flexible (breathing nets recently defined 'soft porous networks' $)^{[17]}$ especially because of the flexible linkage produced by the Ag ions; the geometrical variations reflect in part the nature of the nodes (of moderately increasing dimensions on passing from $\mathrm{Fe}^{\mathrm{III}}$ to $\mathrm{Zn}^{\mathrm{II}}$ to $\mathrm{Cd}^{\mathrm{II}}$ ) but mainly the different contents of the channels. The cell volumes show significant differences with values from $3155.4(4) \AA^{3}$ (3b) to $3622(1) \AA^{3}$ (4k) accompanied by a decrease of the $\boldsymbol{c} / \boldsymbol{a}$ ratio from 1.17 to 1.03 (see Table 1 and Table S5 
in the Supporting Information). ${ }^{[18]}$ This trend implies a reduction of the stretching along $c$ of the channels, with an enlargement of their section (parallel to the $\boldsymbol{a} \boldsymbol{b}$ plane). Indeed the $\mathrm{d}_{3}$ edges (see above) increase from $14.620 \AA$ to $15.939 \AA$ and the free voids from $37.5 \%$ to $47.8 \%$.
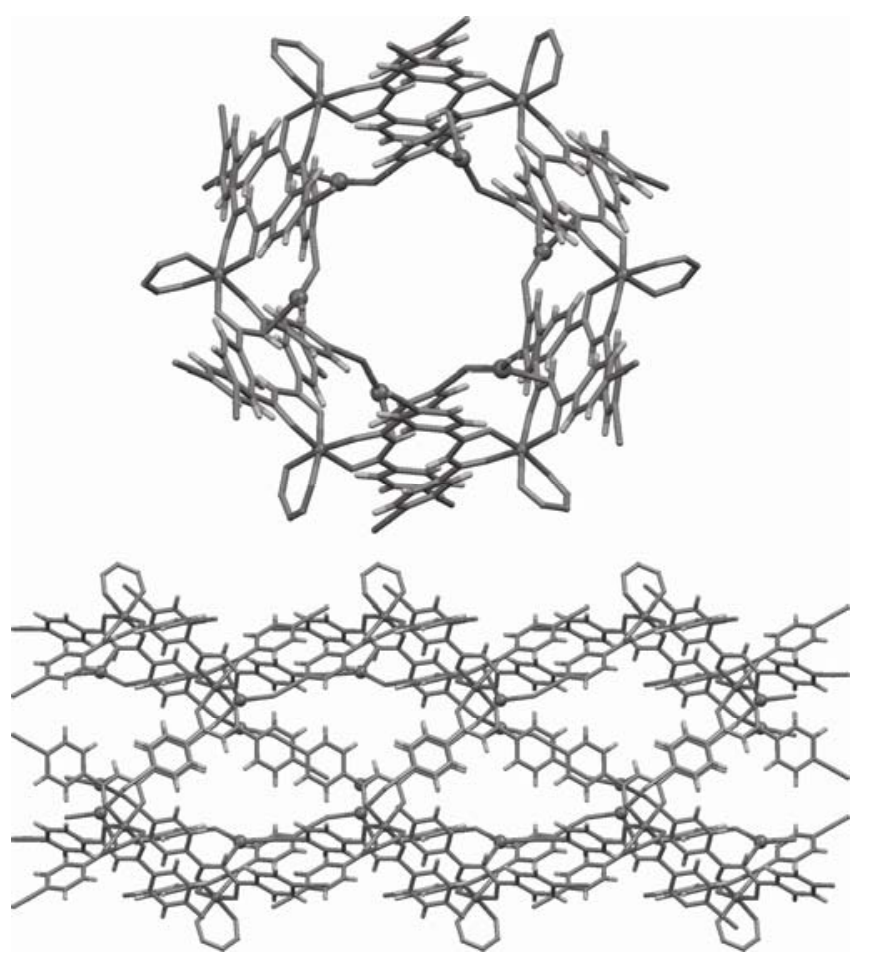

Figure 9. Front (top) and side (bottom) view of a single channel in 4c.

The walls of the channels are formed by the double edges above described (see Fig. 7), with the bridging $\mathrm{Ag}$ atoms somewhat protruding towards the interior of the channels. Thus the walls are covered by phenyl aromatic groups of the ligands, cyano groups and silver atoms.

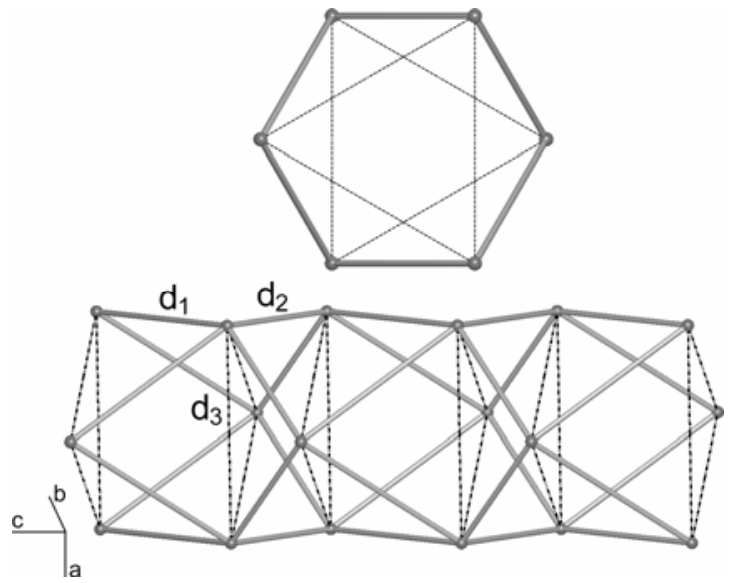

Figure 10. Schematic illustration of the network channels according to the acs topology: front (top) and side (bottom) view.

The silver atoms define the inner section of the channels and, as can be seen from the side view (Fig. 9 bottom), they are disposed at the vertexes of equilateral triangles with edges of about $9.53 \AA$ in $\mathbf{4 c}$ The diameter of the largest sphere that can be contained in these channels is of about $5.4 \AA$ (as computed by the program Cavity, implemented in Platon $)^{[19]}$. The channels can be easily accessed and depleted, so that the guest solvent mixtures are readily lost (at least in part) upon exposure to the air; the overall composition is therefore not constant and can moderately change with time.

It is worth noting that the presence of low-coordinated silver atoms on the walls of the channels, that can be considered as coordinatively unsaturated metal centers (UMCs) ${ }^{[3 \mathrm{~b}, 20]}$ since can adopt diverse coordination environments ${ }^{[21]}$, is of potential interest because they can significantly interact with guest molecules. Indeed most of the cases in which the anions have been better localized show the existence of weak $\mathrm{Ag} \cdots$ anions interactions inside the channels.

Due to the fact that the guest species are severely disordered and can not be located in the X-ray structures the exact stechiometry of these species are not easily determined. Also the elemental analyses are of poor meaning because the guest solvent amounts are quite variable.

To confirm the anionic content in family 4 we have also prepared a polymeric network containing the perrhenate anion, namely $\left[\mathrm{CdL}_{3} \mathrm{Ag}_{3}\right]\left(\mathrm{ReO}_{4}\right)_{2}(\mathbf{4 l})$, and performed an Inductively Coupled Plasma (ICP) analysis on crystals of this species in order to establish the correct stechiometric ratio among the three metals. The results show that the $\mathrm{Re} / \mathrm{Cd}$ ratio (observed value 2.2 ) is essentially correct, while the $\mathrm{Ag} / \mathrm{Cd}$ ratio (observed value 4.3) is too much high. because metallic silver settles inevitably on the surface of the crystals, as also shown by $\mathrm{X}$-ray powder diffraction (XRPD) patterns acquired on grinded crystals. ${ }^{[22]}$

Attempts to establish the nature and amount of the clathrate solvent molecules were performed by ${ }^{1} \mathrm{H}-\mathrm{NMR}$ spectroscopy applied to solutions obtained by suspending weighted crystal samples of the network species in deutero-chloroform for the time necessary to equilibration. Dicloromethane, ethanol and water molecules in a variable ratio fill the channels. For example, we have determined for $\mathbf{4 c}$ (with added standard $=$ pentafluorotoluene): $\left[\mathrm{ZnL}_{3} \mathrm{Ag}_{3}\right]\left(\mathrm{ClO}_{4}\right)_{2}\left(\mathrm{CH}_{2} \mathrm{Cl}_{2}\right)_{0.10-2.47}(\mathrm{EtOH})_{0.46-1.07}\left(\mathrm{H}_{2} \mathrm{O}\right)_{2.20-4.62}$.

These experiments have also shown the insolubility of the crystals in these conditions. No signals of the metalloligands or free ligands were detected in the $\mathrm{CDCl}_{3}$ solution, which implies that the amount of the dissolved building blocks in the mother liquor is too low to be detected by NMR spectroscopy.

The amounts of clathrate solvent molecules are not constant and depend on many experimental variables (like the ambient temperature, the time needed to isolate the crystals and so on...), evidencing that they can be removed very easily from the frameworks.

The TG traces show that the guests are completely lost in the temperature range $30-50^{\circ} \mathrm{C}$ (about $10 \% \mathrm{w} / \mathrm{w}$ ) while the networks result stable up to $c a .270{ }^{\circ} \mathrm{C}$ (see Fig. S3). The process is reversible in that the desolvated samples left at RT adsorb water from the ambient very quickly (about $6 \% \mathrm{w} / \mathrm{w}$ ) (see Fig. S4 for compound 4c). Moreover, during these processes the structure is retained, as evidenced by the XRPD analyses (see Fig. S4). The results show that the desolvation is a reversible single-crystal-to-single-crystal process. ${ }^{[23 a]}$ This behaviour could be essentially ascribed to a nanoporous material of II generation with a permanent porosity assisted by a certain network flexibility (though the possibility that at least in part the distinct interpenetrating pcu nets can moderately change their relative positions during the depletion seems a feature of III generation materials ${ }^{[24]}$. Work is in progress to evaluate the adsorption properties and selectivity of the desolvated species towards vapours and gases. 
Anion exchange: The most promising property of these networks relies on their ability to exchange the anions present in their channels taking into account the insolubility of the crystals in the common solvents. Exchange experiments have been performed to evaluate the preferred interactions of the frameworks with different anions. We have selected as host networks the $\left[\mathrm{ZnL}_{3} \mathrm{Ag}_{3}\right] \mathrm{X}_{2}$. Solv species, namely $\mathbf{4 b}\left(\mathrm{X}^{-}=\mathrm{BF}_{4}^{-}\right), \mathbf{4} \mathbf{c}\left(\mathrm{X}^{-}=\mathrm{ClO}_{4}^{-}\right)$, 4d $\left(\mathrm{X}^{-}=\mathrm{CF}_{3} \mathrm{SO}_{3}^{-}\right)$and $4 \mathbf{e}\left(\mathrm{X}^{-}=\mathrm{PF}_{6}^{-}\right)$. The exchanges were monitored by FT-IR spectroscopy, optical microscopy, XRPD spectra (see Figure 11) and single crystal X-ray diffraction on selected compounds. Some data are reported in Table 2.

The conclusions that can be drawn from these results are that anions can be easily exchanged in single-crystal to single-crystal processes $^{[23 b]}$ and some preferences can be also extracted, i.e.: a) nitrate and perchlorate displace very easily $\mathrm{BF}_{4}^{-}, \mathrm{PF}_{6}^{-}$and triflate anions; b) triflate results very mobile and can be substituted by the other anions; c) using $\mathrm{PF}_{6}{ }^{-}$we can easily substitute triflate while the substitution of perchlorate is only partial. As described above the channel walls are covered by low-coordinated silver ions (UMCs) and these exposed centers can give interactions with the anions. The preferences observed in these exchanges are thus very likely related to the greater anion coordination ability. The channel dimensions, on the other hand, are suitable for all the exchanged anions but the largest ones give only partial exchange (see below).

Competitive experiments have been planned for the future on a more quantitative basis. Anyway, these materials seem good candidates for anion exchange processes.
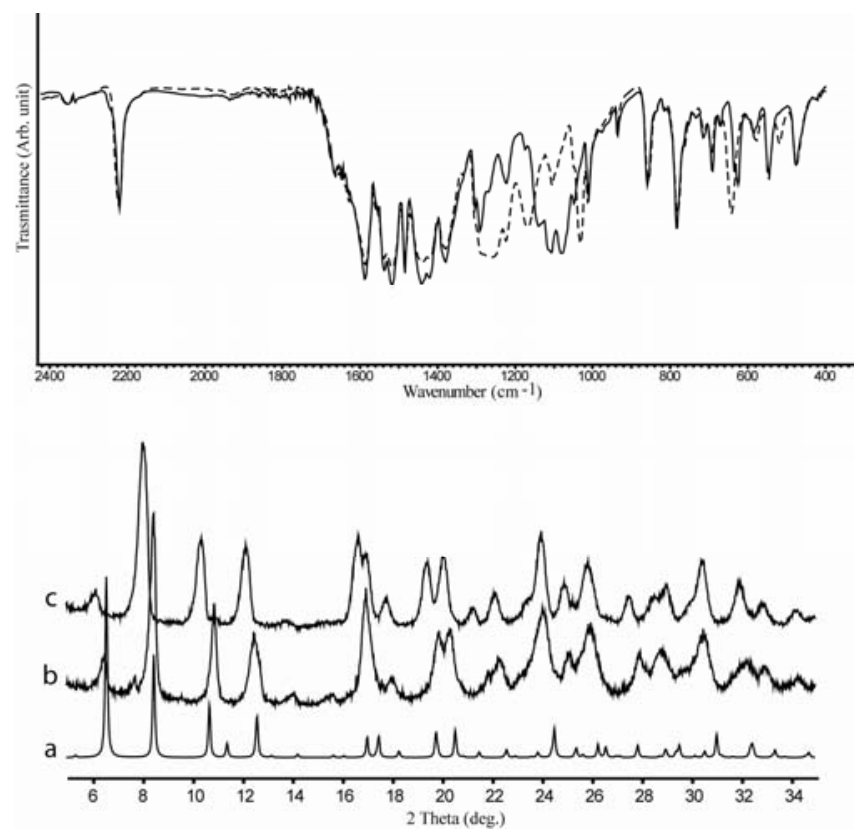

Figure 11. IR spectra of an original sample of compound $\left[\mathrm{Zn}^{\mathrm{II}} \mathrm{L}_{3} \mathrm{Ag}_{3}\right]\left(\mathrm{CF}_{3} \mathrm{SO}_{3}\right)_{2}(\mathbf{4 d})$ (dashed line) and of the same sample exchanged with $\mathrm{NaClO}_{4}$ (full line) in the top. In the bottom: XRPD patterns of $\left[\mathrm{Zn}^{\mathrm{II}} \mathrm{L}_{3} \mathrm{Ag}_{3}\right]\left(\mathrm{CF}_{3} \mathrm{SO}_{3}\right)_{2}$ (4d), calculated (a) and

experimental (b), to be compared with the one obtained after exchange with $\mathrm{NaClO}_{4}(\mathrm{c})$.

Our findings that the $1 \mathrm{D}$ channels are easily accessible and the satisfactory results of the exchange processes with inorganic anions have prompted us to try to insert some different selected anionic species. In this way we have introduced in the network different anions including organometallic motifs, organic molecules and coordination compounds, monitoring the exchange process by FTIR spectroscopy and the structural integrity of the crystals by XRPD analysis. On the basis of the previous exchange experiments we have selected as the starting polymer $\left[\mathrm{ZnL}_{3} \mathrm{Ag}_{3}\right](\mathrm{X})_{2}$ with $\mathrm{X}=$ tetrafluoroborate $(\mathbf{4 b})$, because of the good mobility of these anions.

The exchange experiments were performed by suspending $\mathbf{4 b}$ in solutions of different salts with selected anions. Perrhenate can easily exchange the $\mathrm{BF}_{4}^{-}$anion, and the process can be considered complete after about $1 \mathrm{~h}$, as clearly shown by IR monitoring (see Figure S10). In this way different metal-containing anions can be inserted in the network, generating new heterometallic host-guest systems.

Other exchange experiments have been carried out using also organometallic complex anions. The anionic dinuclear organometallic complex $\left[\mathrm{Re}_{2}(\mathrm{CO})_{6}(\mu-\mathrm{OH})_{3}\right]^{-}$can be introduced in the $1 \mathrm{D}$ channels by exchange. In this case the exchange is slower and after $1 \mathrm{~d}$ it is still only partial. However, the IR spectroscopy clearly indicates that the carbonylic complex is in the framework (see Figure S11). Probably due to the big dimensions of this anion, it cannot diffuse into the interior of the crystal but probably only into the peripheral regions. This last result opens the way to use our framework as heterogeneous support for the immobilization of organometallic compounds employed in homogeneous catalysis.

We have attempted to insert the anion $\left[\mathrm{HFe}(\mathrm{CO})_{4}\right]^{-}$using a fourfold excess of its $\mathrm{NEt}_{4}{ }^{+}$salt in $\mathrm{MeOH}$ but the exchange is quite modest and accompanied by relevant network demolition.

On the other hand the exchange with $\left[\mathrm{Ni}(\mathrm{CN})_{4}\right]^{2-}$ is almost complete in $3 \mathrm{~h}$, but it occurs with some structural modification as evidenced by XRPD; by this way it seems possible to find strategies for the elimination of cyano-metal complexes from a solution.

Partial exchanges are observed using $\mathrm{Na}$ (acetate) and $\mathrm{Na}$ (prolinate). Finally when the exchanges involve anions strongly interacting with the silver atoms of the network (like halides and pseudo-halides or $\mathrm{BH}_{4}^{-}$) drastic structural changes or even demolition are observed from the XRPD spectra.

Table 2. Inorganic anion exchange process results.

\begin{tabular}{lllll}
\hline & $\mathrm{NaBF}_{4}$ & $\mathrm{NaClO}_{4}$ & $\mathrm{NaNO}_{3}$ & $\mathrm{KPF}_{6}$ \\
\hline$\left[\mathrm{Zn}^{\mathrm{II}} \mathrm{L}_{3} \mathrm{Ag}_{3}\right]\left(\mathbf{B F}_{4}\right)_{2}(\mathbf{4 b})$ & & $\mathrm{Y}(1 \mathrm{~h})$ & $\mathrm{Y}(1 \mathrm{~h})$ & $\mathrm{P}(24 \mathrm{~h})$ \\
{$\left[\mathrm{Zn}^{\mathrm{II}} \mathrm{L}_{3} \mathrm{Ag}_{3}\right]\left(\mathbf{C l O}_{4}\right)_{2}(\mathbf{4 c})$} & $\mathrm{N}$ & & $\mathrm{P}(24 \mathrm{~h})$ & $\mathrm{P}(27 \mathrm{~h})$ \\
{$\left[\mathrm{Zn}^{\mathrm{II}} \mathrm{L}_{3} \mathrm{Ag}_{3}\right]\left(\mathbf{C F}_{3} \mathrm{SO}_{3}\right)_{2}(\mathbf{4 d})$} & $\mathrm{Y}(30 \mathrm{~min})$ & $\mathrm{Y}(2 \mathrm{~h})$ & $\mathrm{Y}(15 \mathrm{~min})$ & $\mathrm{Y}(45 \mathrm{~min})$ \\
{$\left[\mathrm{Zn}^{\mathrm{II}} \mathrm{L}_{3} \mathrm{Ag}_{3}\right]\left(\mathbf{P F}_{6}\right)_{2}(\mathbf{4 e})$} & $\mathrm{P}(24 \mathrm{~h})$ & $\mathrm{Y}(3 \mathrm{~h})$ & $\mathrm{Y}(2 \mathrm{~h})$ & \\
\hline
\end{tabular}

$\mathrm{Y}=$ almost complete, as extimated by IR spectra, $\mathrm{P}=$ partial, $\mathrm{N}=$ no exchange. $\mathrm{In}$ parentheses the time of exchange process.

\section{Conclusions}

The well-established synthetic strategy involving the use of rigid metalloligands for the construction of a target structure in this case seems to work well. We have employed the $\beta$-diketone 1,3-bis(4'cyano-phenyl)-1,3-propanedione (HL) to build novel tris-chelate metalloligands $\left.\left[\mathrm{ML}_{3}\right][\mathrm{M}=\mathrm{Co}(\mathrm{III}), \mathrm{Fe}(\mathrm{III}))\right]$ and $\left[\mathrm{ML}_{3}\right]^{-}[\mathrm{M}=$ $\mathrm{Mn}(\mathrm{II}), \mathrm{Co}(\mathrm{II}), \mathrm{Zn}(\mathrm{II}), \mathrm{Cd}(\mathrm{II})]$. These are chiral octahedral building blocks with six exo-oriented cyano donor groups suitable for the construction of nanoporous MOFs by reaction with a number of $\mathrm{AgX}$ silver salts. We have obtained more than twenty heterometallic networks $\left[\mathrm{M}^{\mathrm{III}} \mathbf{L}_{3} \mathrm{Ag}_{3}\right] \mathrm{X}_{3} \cdot$ Solv and $\left[\mathrm{M}^{\mathrm{II}} \mathbf{L}_{3} \mathrm{Ag}_{3}\right] \mathrm{X}_{2} \cdot$ Solv, with the peculiar feature that all exhibit the same type of network structure, in spite of the different metal nodes, ionic charges and $\mathrm{X}^{-}$counteranions. In addition these networks represent the first example of 6fold interpenetration for the pcu topology, belonging to Class IIIa. The nanoporous behaviour and anion exchange ability have been investigated and we succeeded in replacing, at least partially, the 
original anions in the channels with selected anionic species, like coordination complexes and organometallic anions. The walls of the channels are covered by $\mathrm{Ag}$ ions that can interact with the guest species.

These results are of interest both from a structural and from a functional point of view. Due to the easy reproducibility of the 3D network structures many new species based on other M(II) and $\mathrm{M}$ (III) metal ions (via the synthesis of their corresponding metalloligands) can be anticipated. Also mixed-metalloligand frames can be constructed, as we have demonstrated (with compounds $\mathbf{5 a}$ and $\mathbf{5 b}$ ). Heteropolymetallic systems can thus in principle be assembled tacking advantage, in addition, of the possibility to insert metal complexes inside the array via anion exchange processes, as accomplished by us with the insertion of $\mathrm{ReO}_{4}^{-},\left[\operatorname{Re}_{2}(\mathrm{CO})_{6}(\mathrm{OH})_{3}\right]^{-}$and $\left[\mathrm{Ni}(\mathrm{CN})_{4}\right]^{2-}$.

Potential applications to be considered in the future include storage and elimination from solutions of anionic metal complexes or specific organic anions and immobilization of catalytic fragments.

\section{Experimental Section}

Reagents and general procedures: All the commercial reagents and solvents employed (Sigma-Aldrich) were of high-grade purity and used as supplied, without further purification. $\left[\operatorname{Re}_{2}(\mathrm{CO})_{6}(\mathrm{OH})_{3}\right] \mathrm{NEt}_{4}, \mathrm{~K}\left[\mathrm{HFe}(\mathrm{CO})_{4}\right]$ and $\left[\mathrm{Ni}(\mathrm{CN})_{4}\right] \mathrm{K}_{2}$ were synthetized according to the literature methods ${ }^{[25,26,27]}$. All manipulations were performed under aerobic conditions unless standard Schlenk techniques were required. Anhydrous tetrahydrofuran was freshly distilled under nitrogen from sodium/benzophenone. NMR spectra were recorded on Bruker AC300 or AC400 instruments; $\delta$ values are given in ppm relative to tetramethylsilane. Infrared spectra were collected on a Perkin-Elmer PARAGON 1000 FT-IR spectrometer equipped with an i-series FT-IR Microscope. Thermogravimetric analysis (TGA) were performed on a Perkin-Elmer TGA 7 instrument under dynamic nitrogen (total flow rate $20 \mathrm{~cm}^{3} / \mathrm{min}$ ). A ramp rate of $10{ }^{\circ} \mathrm{C} / \mathrm{min}$ in the range $30-650{ }^{\circ} \mathrm{C}$ was used. Powder patterns were recorded on a Philips PW1820 diffractometer $\left(\mathrm{Cu} \mathrm{K}_{\alpha}\right.$ radiation, $\left.\lambda=1.5405 \AA\right)$, in the 5$35^{\circ} 2 \theta$ range $\left(0.02^{\circ}\right.$ and $2.5 \mathrm{~s}$ per step). Magnetic susceptibilities $\left(\chi_{\mathrm{M}}\right)$ were determined at room temperature using a MSB-AUTO (Sherwood Scientific Ltd.) magnetic balance. Three measurements for every sample $(50-100 \mathrm{mg})$ were performed. Diamagnetic corrections were estimated from Pascal's costants. Elemental analyses were carried out at the Microanalytical Laboratory of the University of Milan.Semiquantitative Scanning Electron Microcospy (SEM) analyses were performed with a Jeol JSM-5500LV instrument equipped with EDS spectrometer IXRF EDS 2000. The $\mathrm{Zn} / \mathrm{Re} / \mathrm{Ag}$ ratio was determined by ICP-MS (PerkinElmer, ELAN5500) after microwave digestion of the sample in conc. $\mathrm{HNO}_{3}$.

1,3-bis(4'-cyanophenyl)-1,3-propanedione (HL): Anhydrous THF (32 ml) was added under nitrogen to a dispersion of $60 \% \mathrm{NaH}$ in mineral oil $(1.3833 \mathrm{~g} ; 34.58 \mathrm{mmol})$. The mixture was cooled to $0^{\circ} \mathrm{C}$ and 4-acetylbenzonitrile $(1.6523 \mathrm{~g} ; 11.38 \mathrm{mmol})$ was added. A solution of methyl-4-cyanobenzoate $(2.0131 \mathrm{~g} ; 12.49 \mathrm{mmol})$ in anhydrous THF (8 $\mathrm{ml}$ ) was then added dropwise over a period of $15 \mathrm{~min}$. The pale yellow mixture was refluxed for $16 \mathrm{~h}$ under nitrogen and then quenched with ice. Upon addition of $0.1 \mathrm{M}$ $\mathrm{HCl}$ the ligand $\mathbf{H L}$ was precipitated as a yellow solid, recovered by filtration and washed with distilled $\mathrm{H}_{2} \mathrm{O}$. The filtrate was extracted with AcOEt $(3 \times 100 \mathrm{~mL})$ and the collected organic phases were washed with a saturated solution of $\mathrm{NaCl}$ and dried over $\mathrm{MgSO}_{4}$. Evaporation of the solvent under vacuum gave further HL. Both batches of solid were washed with hot EtOH $(40 \mathrm{~mL})$ obtaining pure $\mathbf{H L}$ as a pale yellow solid. Yield: $70 \%$. IR $\left(\mathrm{KBr}, \mathrm{cm}^{-1}\right)$ 3100, 3068, 3052, 2920, 2854, 2230, 1616, 1590, 1542 $1490,1448,1292,1222,862,832,788,544 .{ }^{1} \mathrm{H}$ NMR $\left(400 \mathrm{MHz}\right.$, acetone-d $\left.\mathrm{d}_{6}\right) \delta 8.39(\mathrm{~d}$ $4 \mathrm{H}), 8.02(\mathrm{~d}, 4 \mathrm{H}), 7.51(\mathrm{~s}, 1 \mathrm{H})$. Elemental analysis calcd. (\%) for $\mathrm{C}_{17} \mathrm{H}_{10} \mathrm{~N}_{2} \mathrm{O}_{2}: \mathrm{C}$ 74.44, H 3.67 N 10.21; found: C 74.31, H 3.58, N 10.43

Tris[1,3-bis(4'-cyanophenyl)-1,3-propanedionatoliron(III) (1a): The ligand HL ( $315.5 \mathrm{mg}, 1.1503 \mathrm{mmol}$ ) was suspended in $15 \mathrm{~mL}$ of water and added with $5.8 \mathrm{~mL}$ of $\mathrm{NaOH} 0.2 \mathrm{M}$. After addition of $4 \mathrm{~mL}$ of a solution of $\mathrm{FeCl}_{3} \cdot 6 \mathrm{H}_{2} \mathrm{O}(103.7 \mathrm{mg}, 0.3836$ $\mathrm{mmol}$ ) the mixture was left under stirring overnight. Compound 1a was recovered as a red solid by filtration, washed with water and dried in the air. Yield: $98 \%$. IR $(\mathrm{KBr}, \mathrm{cm}$ $\left.{ }^{1}\right) 3066,2966,2930,2232,1584,1522,1490,1384,1354,1310,1222,862,788,546$. Magnetic susceptibility at $292 \mathrm{~K}: 5.71 \mu_{\mathrm{B}}$

Tris[1,3-bis(4'-cyanophenyl)-1,3-propanedionato]cobalt(III) (1b): The ligand HL (290.7 mg, $1.0599 \mathrm{mmol}$ ) was suspended in $15 \mathrm{~mL}$ of water and added with $5.3 \mathrm{~mL}$ of $\mathrm{NaOH} 0.2 \mathrm{M}$. After addition of $8 \mathrm{~mL}$ of a solution of $\mathrm{Na}_{3} \mathrm{Co}\left(\mathrm{NO}_{2}\right)_{6}(142.7 \mathrm{mg}, 0.3533$ $\mathrm{mmol}$ ) the mixture was left under stirring for $2 \mathrm{~h}$. Compound $\mathbf{1 b}$ was recovered as a green solid by filtration, washed with water and dried in the air. Yield: $82 \%$. IR ( $\mathrm{KBr}$, $\mathrm{cm}^{-1}$ ) 3122, 3096, 3068, 2918, 2854, 2228, 1614, 1524, 1450, 1384, 1292, 1224, 854, 788,544 .
Tetraethylammoniumtris[1,3-bis(4'-cyanophenyl)-1,3-

propanedionato]manganate(II) (2a): To the ligand HL (401.9 mg, $1.4652 \mathrm{mmol}$ ) EtOH $(260 \mathrm{~mL})$ and a solution of $35 \%$ aq. $\mathrm{NEt}_{4} \mathrm{OH}(754.8 \mathrm{mg}, 1.7940 \mathrm{mmol})$ were added. After addition of $30 \mathrm{~mL}$ of an ethanolic solution of $\mathrm{MnCl}_{2} \cdot 4 \mathrm{H}_{2} \mathrm{O}(96.8 \mathrm{mg}$, $0.4891 \mathrm{mmol}$ ) the mixture was left under stirring for $15 \mathrm{~h}$. Compound 2a was recovered as a dark orange solid by filtration, washed with water and dried in the air. Yield: $61 \%$. Crystals of 2a suitable for structural investigation were obtained by slow diffusion of hexane vapours into a $\mathrm{CH}_{2} \mathrm{Cl}_{2}$ solution in 5 days. IR $\left(\mathrm{KBr}, \mathrm{cm}^{-1}\right) 3068,3042,2984,2950$, $2226,1590,1546,1520,1460,1434,1392,1292,1222,862,780,550$.

Tetraethylammonium

tris[1,3-bis(4'-cyanophenyl)-1,3propanedionato]cobaltate(II) (2b): To the ligand HL (220.8 mg, $0.8050 \mathrm{mmol})$ suspended in $\mathrm{EtOH}(134 \mathrm{~mL})$ a solution of $35 \%$ aq. $\mathrm{NEt}_{4} \mathrm{OH}(403.7 \mathrm{mg}, 0.9595 \mathrm{mmol})$ was added. After addition of $16 \mathrm{~mL}$ of an ethanolic solution of $\mathrm{CoCl}_{2} \cdot 6 \mathrm{H}_{2} \mathrm{O}(63.9 \mathrm{mg}$, $0.2686 \mathrm{mmol}$ ) the mixture was left under stirring for $1 \mathrm{~h}$. Compound $\mathbf{2 b}$ was recovered as a dark orange solid by filtration, washed with water and dried in the air. Yield: $81 \%$. IR $\left(\mathrm{KBr}, \mathrm{cm}^{-1}\right) 3068,3042,2988,2226,1590,1546,1518,1464,1438,1392,1294$, 1224, 862, 768, 550. ${ }^{1} \mathrm{H}$ NMR (300 MHz, acetone- $\mathrm{d}_{6}$ ) $\delta 15.55$ (br, $\left.12 \mathrm{H}\right), 12.26$ (br, 12 H), $3.06(\mathrm{br}, 8 \mathrm{H}), 1.08(\mathrm{br}, 12 \mathrm{H}),-11.70(\mathrm{br}, 3 \mathrm{H})$. Crystals suitable for structural investigation were obtained by slow diffusion of ethyl ether vapours into a solution of 2b in THF after 10 days.

Tetraethylammonium tris[1,3-bis(4'-cyanophenyl)-1,3-propanedionato]zincate(II) (2c): To the ligand HL $(617.2 \mathrm{mg}, 2.2503 \mathrm{mmol})$ suspended in EtOH $(70 \mathrm{~mL})$ a solution of $35 \%$ aq. $\mathrm{NEt}_{4} \mathrm{OH}(1120.6 \mathrm{mg}, 2.6634 \mathrm{mmol})$ was added. After addition of 5 $\mathrm{mL}$ of an ethanolic solution of $\mathrm{ZnCl}_{2}(102.9 \mathrm{mg}, 0.7550 \mathrm{mmol})$ the mixture was left under stirring overnight. Compound 2c was recovered as a yellow solid by filtration, washed with water and dried in the air. Yield: $75 \%$. IR $\left(\mathrm{KBr}, \mathrm{cm}^{-1}\right) 3068,3042,2986$, 2950, 2228, 1592, 1546, 1522, 1464, 1430, 1392, 1294, 1224, 862, 780, 550. ${ }^{1} \mathrm{H}$ NMR $\left(300 \mathrm{MHz}\right.$, acetone- $\left.\mathrm{d}_{6}\right) \delta 8.18(\mathrm{~d}, 12 \mathrm{H}), 7.77(\mathrm{~d}, 12 \mathrm{H}), 6.72(\mathrm{~s}, 3 \mathrm{H}), 3.52(\mathrm{q}, 12 \mathrm{H})$, $1.43(\mathrm{br}, 8 \mathrm{H})$. Crystals suitable for structural investigation were obtained by slow diffusion of n-hexanes into a solution of $2 \mathbf{c}$ in $\mathrm{CH}_{2} \mathrm{Cl}_{2}$ after 5 days

\section{Tetraethylammoniun}

tris[1,3-bis(4'-cyanophenyl)-1,3-

propanedionato]cadmate(II) (2d)

To the ligand HL $(174.8 \mathrm{mg}, 0.6373 \mathrm{mmol})$ suspended in EtOH $(15 \mathrm{~mL})$ a solution of $35 \%$ aq. $\mathrm{NEt}_{4} \mathrm{OH}(326.4 \mathrm{mg}, 0.7758 \mathrm{mmol})$ was added. After addition of $4 \mathrm{~mL}$ of an ethanolic solution of $\mathrm{CdNO}_{3} \cdot 4 \mathrm{H}_{2} \mathrm{O}(65.5 \mathrm{mg}, 0.2123 \mathrm{mmol})$ the mixture was left under stirring overnight. Compound 2d was recovered as a yellow solid by filtration, washed with water and dried in the air. Yield: $87 \%$. IR $\left(\mathrm{KBr}, \mathrm{cm}^{-1}\right) 3068,3042,2982,2950$, 2226, 1546, 1590, 1520, 1458, 1428, 1392, 1292, 1272, 1222, 856, 778, 548. ${ }^{1} \mathrm{H}$ NMR $\left(300 \mathrm{MHz}\right.$, acetone- $\left.\mathrm{d}_{6}\right) \delta 8.15(\mathrm{~d}, 12 \mathrm{H}) 7.78(\mathrm{~d}, 12 \mathrm{H}), 6.65(\mathrm{~s}, 3 \mathrm{H}), 3.52(\mathrm{q}, 8 \mathrm{H})$, $1.40(\mathrm{t}, 12 \mathrm{H})$. Crystals suitable for structural investigation were obtained by diffusion of toluene into a $\mathrm{CH}_{2} \mathrm{Cl}_{2}$ solution of $\mathbf{2} \mathbf{d}$ after 4 days.

Bis(triphenylphosphine)iminium 1,3-bis(4'-cyanophenyl)-1,3-propanedionate (LPPN): The ligand HL $(235.0 \mathrm{mg}, 0.8568 \mathrm{mmol})$ and $0.2 \mathrm{M} \mathrm{NaOH}(5.2 \mathrm{~mL}, 1.04$ $\mathrm{mmol})$ were mixed and stirred in distilled $\mathrm{H}_{2} \mathrm{O}(30 \mathrm{~mL})$ until a yellow dense liquid was obtained. A solution of bis(triphenylphosphine)iminium chloride $(491.1 \mathrm{mg}, 0.8556$ $\mathrm{mmol})$ dissolved in a $\mathrm{MeOH} / \mathrm{H}_{2} \mathrm{O}(10: 3,26 \mathrm{~mL})$ mixture was added dropwise. The resulting solution was stirred at room temperature for $50 \mathrm{~min}$ and filtered to obtain a yellow solid. The solid was washed with distilled water and dried in the air. Yield: $505.7 \mathrm{mg}$ (0.6229 mmol, $73 \%)$.

Bis(triphenylphosphine)iminium

propanedionate]M(II)

In a general procedure LPPN $(86.8 \mathrm{mg}, 1.1069 \mathrm{mmol})$ was dissolved in EtOH $(10 \mathrm{~mL})$ and a solution of $\mathrm{MX}_{2}(11.3 \mathrm{mg}, 0.0366 \mathrm{mmol})$ in $\mathrm{EtOH}(4 \mathrm{~mL})$ was added dropwise. The mixture was stirred at room temperature for $17 \mathrm{~h}$ and filtered to recover the desired product, which was washed with distilled water and a minimum amount of EtOH.

$\mathbf{M}=\mathbf{C d}$ (2d'): $\mathrm{MX}_{2}=\mathrm{Cd}\left(\mathrm{NO}_{3}\right)_{2} \cdot 4 \mathrm{H}_{2} \mathrm{O}$. Yield: $70 \%$ (yellow solid). IR $\left(\mathrm{KBr}, \mathrm{cm}^{-1}\right) 3058$, 2228, 1592, 1546, 1522, 1458, 1438, 1366, 1290, 1268, 858, 778, 544, 534. ${ }^{1} \mathrm{H}$ NMR $\left(300 \mathrm{MHz}\right.$, acetone $\left.\mathrm{d}_{6}\right) \delta 8.12(\mathrm{~d}, 12 \mathrm{H}), \delta$ 7.54-7.76 (m, $30 \mathrm{H} \mathrm{PPN}$ and $\left.12 \mathrm{H}\right), \delta 6.62$ $(\mathrm{s}, 3 \mathrm{H}, \mathrm{CH})$. Crystals suitable for structural investigation were obtained by slow diffusion of $n$-hexane into a solution of $2 \mathbf{d}^{\prime}$ in $\mathrm{CH}_{2} \mathrm{Cl}_{2}$ after 8 days.

$\mathbf{M}=\mathbf{Z n}$ (2''): $\mathrm{MX}_{2}=\mathrm{ZnCl}_{2}$. Yield: $87 \%$ (yellow solid.). IR $\left(\mathrm{KBr}, \mathrm{cm}^{-1}\right)$ 3058, 2226 , 1592, 1546, 1522, 1466, 1430, 1384, 1292, 1224, 860, 778, 544, 534. ${ }^{1} \mathrm{H}$ NMR (300 MHz, acetone $\left.\mathrm{d}_{6}\right) \delta 8.15(\mathrm{~d}, 12 \mathrm{H}), \delta 7.54-7.76(\mathrm{~m}, 30 \mathrm{H} \mathrm{PPN}$ and $12 \mathrm{H}), \delta 6.69(\mathrm{~s}, 3$ $\mathrm{H})$.

\section{Synthesis of $\left\{\left[\mathrm{Fe}^{\mathrm{III}} \mathrm{L}_{3} \mathrm{Ag}_{3}\right]\left(\mathrm{ClO}_{4}\right)_{3}\right\}$ Solv (3d)}

A typical synthesis of a member of family 3 MOFs is described here:

1a (104.4 mg, $0.1192 \mathrm{mmol}$ ) was dissolved in $40 \mathrm{~mL}$ of $\mathrm{CH}_{2} \mathrm{Cl}_{2}$ (Sol. A) and $\mathrm{AgClO}_{4}$ $(74.2 \mathrm{mg}, 0.3579 \mathrm{mmol})$ in $40 \mathrm{ml}$ of acetone (Sol. B). Portions of solution B $(20 \mathrm{~mL})$ were slowly added to solution A $(20 \mathrm{~mL})$ in two crystallizing dishes $(50 \mathrm{~mL})$. Yellow microcrystalline powders formed in about 5 days on slowly concentrate the two solutions left in the air. The solid was collected on a Buckner funnel, washed with dichloromethane and dried in the air to obtain pure 3d. Yield: $84 \%$. IR $\left(\mathrm{KBr}, \mathrm{cm}^{-1}\right)$ $3100,3081,3054,2260,1581,1536,1489,1414,1353,1284,1229,1131,1063,868$, $834,795,618$. Magnetic susceptibility at $298 \mathrm{~K}: 6.03 \mu_{\mathrm{B}}$.

Microcrystalline samples of the following polymers were obtained on using the proper silver salt with the procedure described above:

3a: Yield: 82 \%; 3b:Yield: $79 \%$. IR $\left(\mathrm{KBr}, \mathrm{cm}^{-1}\right) 3100,3072,3053,2264,1622,1582$, 1534, 1490, 1417, 1360, 1317, 1231, 1126, 1015, 858, 801, 700. 3c: Yield: 75 \%. IR $\left(\mathrm{KBr}, \mathrm{cm}^{-1}\right) 3103,3075,3054,2263,1580,1538,1496,1414,1352,1263,1231,1065$, $938,803,698,619$. Crystals suitable for X-ray analyses of 3a-3g were obtained by slow 
diffusion method of dicloromethane solutions of the neutral monomers and acetone solutions of the proper silver salts.

\section{Synthesis of $\left\{\left[\mathrm{Zn}^{\mathrm{II}} \mathrm{L}_{3} \mathrm{Ag}_{3}\right]\left(\mathrm{BF}_{4}\right)_{2}\right\}$ 'Solv $(4 \mathrm{~b})$}

A typical synthesis of a member of family 4 MOFs is described here:

2c $(502.0 \mathrm{mg}, \mathrm{mmol})$ was dissolved in $215 \mathrm{~mL}$ of $\mathrm{CH}_{2} \mathrm{Cl}_{2}$ (Sol. A) and $\mathrm{AgBF}_{4}$ (288.9 $\mathrm{mg}, \mathrm{mmol})$ in $215 \mathrm{~mL}$ of EtOH (Sol. B). Portions of solution B ( $20 \mathrm{~mL})$ were slowly added to solution A $(20 \mathrm{~mL})$ in ten crystallizing dishes $(50 \mathrm{ml})$. Yellow microcrystalline powders formed in about 5 days on slowly concentrate the two solutions left in the air. The solid was collected on a Buckner funnel, washed with dichloromethane and dried in the air to obtain $\mathbf{4 b}$. Yield: $80.4 \%$. IR $\left(\mathrm{KBr}, \mathrm{cm}^{-1}\right) 3098$, $2252,1590,1544,1510,1444,1432,1388,1298,1224,1054,858,790,546$

Microcrystalline samples of the following polymers were obtained on using the prope silver salt with the procedure described above. 4c: Yield: 73\%. IR $\left(\mathrm{KBr}, \mathrm{cm}^{-1}\right) 3096$ 3070, 2986, 2230, 1594, 1544, 1524, 1448, 1426, 1390, 1296, 1236, 1146, 1116, 1078 , 862, 786, 626, 552. 4d: Yield: 74\%. IR $\left(\mathrm{KBr}, \mathrm{cm}^{-1}\right) 3072,2984,2230,1592,1544,1522$ 1446, 1426, 1384, 1262, 858, 784, 546. 4e: Yield: $70 \%$. IR $\left(\mathrm{KBr}, \mathrm{cm}^{-1}\right) 3096,2230$ 1594, 1544, 1522, 1444, 1428, 1386, 1296, 1224, 862, 786, 546. 4h: Yield: 83\%. IR $\left(\mathrm{KBr}, \mathrm{cm}^{-1}\right) 3070,2248,2230,1592,1544,1522,1446,1432,1384,1296,1224,858$, 782, 546. 4j: Yield: $86 \%$. 4k Yield: $82 \%$

Crystals suitable for X-ray analyses of $4 \mathbf{a}-4 \mathbf{k}$ were obtained by slow diffusion method of dicloromethane solutions of the anionic monomers and ethanolic solutions of the proper silver salts.

\section{Synthesis of $\left[\mathrm{Cd}^{\mathrm{II}} \mathrm{L}_{3} \mathrm{Ag}_{3}\right]\left(\mathrm{ReO}_{4}\right)_{2} \cdot \operatorname{Solv}(4 \mathrm{l})$}

Crystals of $4 \mathbf{l}$ suitable for $\mathrm{X}$-ray analysis were obtained by layering respectively an ethanolic solution of $\mathrm{ReO}_{4}(\mathrm{NBu})_{4}$ (4 eq.) and an ethanolic solution of silve tetrafluoroborate ( 3 eq.) onto a dichloromethane solution containing the monomer $2 \mathbf{d}$ (1 eq.). Relative ratios $\mathrm{Cd} / \mathrm{Re} / \mathrm{Ag}$ determined by ICP analysis: 4.4/1/2.2 (calcd. 3/1/2). The high value for silver can be ascribed to the deposition of metallic silver on the crystal surface, as evidenced by the XRPD analyses.

\section{Synthesis of $\left\{\left[\mathrm{Zn}_{\mathrm{x}} \mathrm{M}_{\mathrm{y}} \mathrm{L}_{3} \mathrm{Ag}_{3}\right]\left(\mathrm{ClO}_{4}\right)_{\mathrm{z}}\left[\mathrm{M}=\mathrm{Cd}^{\mathrm{II}}, \mathrm{Z}=2\right.\right.$, (5a); $\left.\mathrm{M}=\mathrm{Fe}^{\mathrm{III}}, \mathrm{z}=2 \mathrm{x}+3 \mathrm{y},(5 \mathrm{~b})\right]$}

Crystals of $\mathbf{5 a}$ and $\mathbf{5 b}$ suitable for X-ray analyses were obtained by slow diffusion of ethanolic solutions of silver perchlorate into dichloromethane solutions containing equimolar amounts of monomers $\mathbf{2 c} / \mathbf{2 d}$ and $\mathbf{2 c} / \mathbf{1}$ a respectively.

\section{Anion Exchange Procedures (with $\mathrm{NaBF}_{4} \mathrm{NaClO}_{4} \mathrm{NaNO}_{3}, \mathrm{KPF}_{6}$ )}

Compounds $4 \mathbf{b}-\mathbf{e}(\sim 100 \mathrm{mg})$ were suspended in saturated methanolic solutions $(30 \mathrm{ml})$ of $\mathrm{NaClO}_{4}, \mathrm{NaNO}_{3}, \mathrm{KPF}_{6}$, or $\mathrm{NaBF}_{4}$. The exchange process was monitored by IR spectroscopy at regular interval of $15 \mathrm{~min}$ or $1 \mathrm{~h}$. Before every measurement the sample was filtered, washed with methanol and dried in the air. To verify that the structure of the networks was retained during the exchange process XRPD spectra were recorded.

Exchange with $\left(\mathrm{NBu}_{4}\right) \mathbf{R e O}_{4}$ : A sample of $51.1 \mathrm{mg}$ of $\mathbf{4 b}$ was added to a methanolic solution $0.050 \mathrm{M}(4 \mathrm{~mL})$ of $\left(\mathrm{NBu}_{4}\right) \mathrm{ReO}_{4}$ and the mixture was left to stir at room temperature. The solid was then recovered by filtration, washed with methanol and dried in the air. The exchange process was confirmed by the appearance of an absorption band at $c a .915 \mathrm{~cm}^{-1}$ in the IR spectrum due to the $\mathrm{ReO}_{4}^{-}$anion and the disappearance of the broad band due to the $\mathrm{BF}_{4}^{-}$anion at $1054 \mathrm{~cm}^{-1}$. After $1 \mathrm{~h}$ the process could be considered complete. The XRPD analyses confirm the integrity of the exchanged network.

Exchange with $\left[\mathbf{R e}_{2}(\mathbf{C O})_{6}(\mathbf{O H})_{3}\right]\left(\mathbf{N E t}_{4}\right)$ : A sample of $50.0 \mathrm{mg}$ of $\mathbf{4 b}$ was added to a methanolic solution $0.034 \mathrm{M}(10 \mathrm{~mL})$ of $\left[\operatorname{Re}_{2}(\mathrm{CO})_{6}(\mathrm{OH})_{3}\right]\left(\mathrm{NEt}_{4}\right)$ and the mixture was left to stir at room temperature for $1 \mathrm{~d}$. The solid was then recovered by filtration, washed with methanol and dried in the air. The IR spectrum acquired on the exchanged solid shows the presence of carbonylic bands at 1998 and $1882 \mathrm{~cm}^{-1}$. The IR bands due to $\mathrm{BF}_{4}{ }^{-}$anion decrease in intensity and move from 1054 to $1084 \mathrm{~cm}^{-1}$. The persistence of bands due to the $\mathrm{BF}_{4}^{-}$anion evidence a partial exchange process. The $v(\mathrm{CN})$ band moves from 2252 to $2230 \mathrm{~cm}^{-1}$. The XRPD analyses confirm the integrity of the exchanged network.

Exchange with $\mathbf{K}_{2}\left[\mathrm{Ni}(\mathbf{C N})_{4}\right]$ : A sample of $81.2 \mathrm{mg}$ of $\mathbf{4 b}$ was added to a $\mathrm{MeOH} / \mathrm{H}_{2} \mathrm{O}$ (2:1) solution $0.013 \mathrm{M}(30 \mathrm{~mL})$ of $\mathrm{K}_{2}\left[\mathrm{Ni}(\mathrm{CN})_{4}\right]$ and the mixture was left to stir at room temperature for $3 \mathrm{~h}$. A colour change from yellow-brown to green was observed in few minutes. The solid was then recovered by filtration, washed with water and dried in the air. The IR spectrum shows the presence of $v(\mathrm{CN})$ bands at 2238 and $2230 \mathrm{~cm}^{-1}$ (attributed to the network) and $2168 \mathrm{~cm}^{-1}$ due to exchanged $\left[\mathrm{Ni}(\mathrm{CN})_{4}\right]^{2-}$. An additional less intense $v(\mathrm{CN})$ band at $2130 \mathrm{~cm}^{-1}$ is also present that has not been attributed. Note that the $v(\mathrm{CN})$ band of the free $\left[\mathrm{Ni}(\mathrm{CN})_{4}\right]^{2-}$ is at $2130 \mathrm{~cm}^{-1}$. The absorption bands due to the $\mathrm{BF}_{4}{ }^{-}$anion disappear, evidencing a complete exchange process. The XRPD analysis on the exchanged solid shows some structural modifications.

To exclude a possible role of water in producing the structural modification during the exchange process a sample of compound $\mathbf{4 b}$ was left in a methanol/water mixture $(2: 1)$ for the same time as that required for the exchange experiment; the same type of pattern as the original of $\mathbf{4 b}$ was detected by XRPD

Exchange with KSCN: A sample of $12.6 \mathrm{mg}$ of $\mathbf{4 b}$ was added to a saturated methanolic solution $(4 \mathrm{~mL})$ of $\mathrm{KSCN}$ and immediately the mixture changed color from brown to yellow. The solid was then recovered by filtration, washed with methanol and dried in the air. The IR spectrum acquired on the exchanged solid shows a band due to the presence of $\mathrm{SCN}^{-}$at $2088 \mathrm{~cm}^{-1}$ and a lowering in the intensity of the bands due to the $\mathrm{BF}_{4}{ }^{-}$anion. The XRPD analysis shows a complete trasformation of the network.

Exchange with $\mathrm{NaBH}_{4}$ : A sample of $66.8 \mathrm{mg}$ of $\mathbf{4 b}$ was added to a methanolic solution $0.484 \mathrm{M}(30 \mathrm{~mL})$ of $\mathrm{NaBH}_{4}$ and the mixture was left to stir at room temperature. Immediately the color changed from brown to green. After $5 \mathrm{~min}$ the solid was recovered by filtration, washed with methanol and dried in the air. The XRPD analysis shows a degradation of the network and the formation of metallic silver.

Exchange with $\mathrm{Na}$ (prolinate): A sample of $106.0 \mathrm{mg}$ of $\mathbf{4 b}$ was added to a methanolic solution $0.010 \mathrm{M}(30 \mathrm{~mL})$ of $\mathrm{Na}$ (prolinate) $(\mathrm{pH}=8)$ and the mixture was left to stir at room temperature for $1 \mathrm{~h}$. The solid was then recovered by filtration, washed with methanol and dried in the air. The IR spectrum acquired on the exchanged solid, after 1 $\mathrm{h}$, shows a change in the absorption region of $\mathrm{BF}^{-}$. No further changes were detected in the IR spectrum. The XRPD analysis confirms the integrity of the exchanged network but some new peaks appeared. These data do not give a clear evidence on the exchange process.

Exchange with $\mathrm{Na}$ (acetate): A sample of $106.0 \mathrm{mg}$ of $\mathbf{4 b}$ was added to a methanolic solution $0.020 \mathrm{M}(30 \mathrm{~mL})$ of $\mathrm{Na}$ (acetate) and the mixture was left to stir at room temperature for $3 \mathrm{~h}$. The solid was then recovered by filtration, washed with methanol and dried in the air. The IR spectrum acquired on the exchanged solid shows a lowering of the intensity of the absorption bands due to $\mathrm{BF}_{4}{ }^{-}$anion. The presence in the network of acetate was difficult to confirm because its bands fall under the bands due to the network. The $v(\mathrm{CN})$ band shifts from 2252 to $2229 \mathrm{~cm}^{-1}$. The XRPD analysis confirm the preservation of the network.

Analysis by ${ }^{1} \mathbf{H}$ NMR of guest solvents: $2 \mu \mathrm{L}$ of 2,3,4,5,6-pentafluorotoluene were added to $\mathrm{CDCl}_{3}(0.75 \mathrm{~mL})$ in a NMR tube and the ${ }^{1} \mathrm{H}$ NMR spectrum of this solution was acquired. Crystals (in the range 5-10 mg) of compounds $\mathbf{4 b}-\mathbf{e}, \mathbf{4 h}$ were removed from the mother liquor, dried on filter paper, weightened and quickly transferred in the NMR tubes. ${ }^{1} \mathrm{H}$ NMR spectra were aquired after about 3 h. No changes in the relative ratios between signals were detected after this period. The signal at $2.26 \mathrm{ppm}$ due to the $\mathrm{CH}_{3}$ group of 2,3,4,5,6-pentafluorotoluene was used as internal standard to compute the amounts of chlatrate solvents. For every sample three experiments were performed. The resulting formulae are the following: $\left[\mathrm{ZnL}_{3} \mathrm{Ag}_{3}\right]\left(\mathbf{B F}_{4}\right)_{2}\left(\mathrm{CH}_{2} \mathrm{Cl}_{2}\right)_{0.36-1.00}(\mathrm{EtOH})_{0.87-1.20}\left(\mathrm{H}_{2} \mathrm{O}\right)_{1.93-4.52}(\mathbf{4 b})$ $\left[\mathrm{ZnL}_{3} \mathrm{Ag}_{3}\right]\left(\mathbf{C l O}_{4}\right)_{2}\left(\mathrm{CH}_{2} \mathrm{Cl}_{2}\right)_{0.10-2.47}(\mathrm{EtOH})_{0.46-1.07}\left(\mathrm{H}_{2} \mathrm{O}\right)_{2.20-4.62}(\mathbf{4 c})$ $\left[\mathrm{ZnL}_{3} \mathrm{Ag}_{3}\right]\left(\mathbf{C F}_{3} \mathbf{S O}_{3}\right)_{2}\left(\mathrm{CH}_{2} \mathrm{Cl}_{2}\right)_{0.76}(\mathrm{EtOH})_{1.12-1.15}\left(\mathrm{H}_{2} \mathrm{O}\right)_{1.95-2.79}(\mathbf{4 d})$ $\left[\mathrm{ZnL}_{3} \mathrm{Ag}_{3}\right]\left(\mathbf{P F}_{6}\right)_{2}\left(\mathrm{CH}_{2} \mathrm{Cl}_{2}\right)_{0.18-0.20}(\mathrm{EtOH})_{0.47-1.70}\left(\mathrm{H}_{2} \mathrm{O}\right)_{0.61-1.55}(\mathbf{4 e})$; $\left[\mathrm{ZnL}_{3} \mathrm{Ag}_{3}\right]\left(\mathrm{NO}_{3}\right)_{2}\left(\mathrm{CH}_{2} \mathrm{Cl}_{2}\right)_{0.49-0.82}(\mathrm{EtOH})_{1.25-1.85}\left(\mathrm{H}_{2} \mathrm{O}\right)_{3.11-3.41}(\mathbf{4 h})$

Thermogravimetric analyses (TGA): TGA on compounds $4 \mathbf{b}-\mathbf{e}$ and $4 \mathbf{h}$, were performed in the range $30-650^{\circ} \mathrm{C}$. They show a weight loss of about $10 \%$ in the range $30-50{ }^{\circ} \mathrm{C}$ due to de-solvation process and a second weight loss of about $50 \%$ due to network decomposition that starts at different temperature for the different polymers (range $220-290^{\circ} \mathrm{C}$ ) (See Figure S3). On polymer 4c the de-solvation process was further monitored heating two different samples at $100^{\circ} \mathrm{C}$ and then cooling them differentely in the air at room temperature or under nitrogen atmosphere at room temperature. TG analyses on these samples heated up to $100^{\circ} \mathrm{C}$ show a weight loss of about $6 \%$ for the sample cooled in the air and no weight loss for the sample cooled under nitrogen (See Figure S4).

Crystallography: The crystal data for 1,3-bis(4'-cyanophenyl)-1,3-propanedione (HL) and for the metalloligands $\mathbf{1 b}, \mathbf{2 b}-\mathbf{d}$ and $\mathbf{2 d}$ ' are listed in Table S1 and those for the MOFs 3a-b, $\mathbf{4 b}-\mathbf{c}, \mathbf{4 e}, \mathbf{4} \mathbf{i}-\mathbf{l}$ and $\mathbf{5 b}$ in Table S3. Selected bond distances and angles are given in Tables S2 and S4. The data were collected on a SMART-CCD Bruker diffractometer with Mo K $\alpha$ radiation $(\lambda=0.71073 \AA)$. Empirical absorption correction $(\mathrm{SADABS})^{[28]}$ was applied to all data. The structures were solved by direct methods $\left(\right.$ SIR97) ${ }^{[29]}$ and refined by full-matrix least-squares on $\mathrm{F}^{2}$ (SHELX-97) ${ }^{[30]}$ with WINGX interface. ${ }^{[31]}$ All hydrogen atoms were placed in geometrically calculated positions and thereafter refined using a riding model with $\mathrm{Uiso}(\mathrm{H})=1.2 \mathrm{Ueq}(\mathrm{C})$, except for the ligand HL where the hydrogen atoms were found and refined. Anisotropic thermal parameters were assigned to all the non-hydrogen atoms but in some cases. In details, isotropic thermal parameters were assigned in compound $\mathbf{2} \mathbf{b}$, to chlatrate THF molecules and to the tetraethylammonium cation, and in compounds 3a and $\mathbf{4 l}$ to all atoms of anions but the heavier ones ( $\mathrm{S}$ and Re). The accessible free voids were calculated by PLATON. ${ }^{[19]}$ Further details on the refinements of the disordered groups observed, can be found in the cif file under refine special details keyword. The crystals of $\mathbf{1 b}$ and $\mathbf{3 b}$ are unstable showing high decay $24 \%$ and $12 \%$ respectively, hence resulting in high $\mathrm{R}$ values. Except for the ligand $\mathbf{H L}$, crystals of all monomers and polymers are unstable in air, and were collected under mineral oil. All the crystals tested for $\mathbf{1 b}, \mathbf{2} \mathbf{b}, \mathbf{3 a}-\mathbf{b}, \mathbf{4} \mathbf{b}-\mathbf{c}$, 4i-l showed also weak diffraction, hence resulting in high $\mathrm{R}$ values. All structures of polymers and $\left[\mathrm{FeL}_{2}(\mu-\mathrm{OMe})\right]_{2}$ contain disordered anions and solvents (such as dichloromethane, ethanol, methanol and water). When it was difficult to refine a consistent model for the solvents or the anions, the contribution of them was subtracted from the observed structure factors according to the BYPASS procedure ${ }^{[32]}$ as implemented in PLATON with the command SQUEEZE. In $\mathbf{4 c}, \mathbf{4 k - \mathbf { k }}$ and $\mathbf{5 b}$, the anions have been refined with total occupancy of $2 / 3$ for the electroneutrality. In $4 \mathbf{e}$ only one exafluorophosphate molecule (disordered on three positions) was located. In $\mathbf{4 j}$ the perchlorate anions have been refined with a constrain of total occupancy of 4 perchlorate molecules per unit cell (instead of 8 for the two Wyckoff positions $6 \mathrm{~d}$ and $2 \mathrm{~g}$ ) for the electroneutrality. In $\mathbf{3} \mathbf{b}, \mathbf{4} \mathbf{b}$ and $\mathbf{4 i}$ the anions are strongly disordered and cannot be located, so their contribution was subtracted with SQUEEZE, nonetheless we report the anions in the formula since they are indeed present in the solid. The diagrams were produced using ORTEP ${ }^{[33]}$, TOPOS $^{[34]}$ and Mercury $\left[{ }^{35]}\right.$ programs.

CCDC reference numbers: $776202-776218$

\section{Acknowledgements}


This work was supported by MIUR within the projects PRIN 2006 "POLYM2006: Innovative experimental and theoretical methods for the study of crystal polymorphism - a multidisciplinary approach"' and PRIN 2008 "CRYSFORMS Design, properties and preparation of molecular crystals and co-crystals".

[1] a) M. O'Keeffe, M. Eddaoudi, H. Li, T.M. Reineke, O.M. Yaghi, J. Solid State Chem., 2000, 152, 2; b) M. Eddaoudi, D.B. Moler, H. Li, B.L. Chen, T.M. Reineke, M. O'Keeffe, O.M. Yaghi, Acc. Chem. Res., 2001, 34, 319; c) O.M. Yaghi, M. O'Keeffe, N.W. Ockwig, H.K. Chae, M. Eddaoudi, J. Kim, Nature, 2003, 423, 705; d) B. Moulton, M.J. Zaworotko, Chem. Rev. 2001, 101, 1629; e) P.J. Hagrman, D. Hagrman, J. Zubieta, Angew. Chem., Int. Ed., 1999, 38, 2638; f) A.J. Blake, N.R. Champness, P. Hubberstey, W.-S. Li, M.A. Withersby, M. Schroder, Coord. Chem. Rev., 1999, 183, 117; g) G. Ferey, Chem. Soc. Rev., 2008, 37, 191; h) S.R. Batten, R. Robson, Angew. Chem., Int. Ed., 1998, 37, 1460; i) R. Robson, J. Chem. Soc., Dalton Trans. 2000, 3735; j) L. Carlucci, G. Ciani, D.M. Proserpio, Coord. Chem. Rev., 2003, 246, 247; k) L. Carlucci, G. Ciani, D.M. Proserpio, "Networks, Topologies, and Entanglements" in Making Crystals by Design - Methods, Techniques and Applications. (eds. D. Braga and F. Grepioni), Wiley-VCH Weinheim, 2007, Ch. 1.3

[2] a) C. Janiak, Dalton Trans. 2003, 2781; b) S.L. James, Chem.Soc. Rev. 2003, 32 , 276; c) S. Kitagawa, R. Kitaura, S. Noro, Angew. Chem., Int. Ed., 2004, 43 2334; d) J.-R. Li, R.J. Kuppler, H.-C. Zhou, Chem. Soc. Rev., 2009, 38, 1477; e) J.Y. Lee, O.K. Farha, J. Roberts, K.A. Scheidt, S.T. Nguyen, J.T. Hupp, Chem. Soc. Rev., 2009, 38, 1450; f) L. Ma, C. Abney, W. Lin, Chem. Soc. Rev., 2009, 38, 1248; g) O.R. Evans, W. Lin, Acc. Chem. Res., 2002, 35, 511; h) D. Bradshaw, J.B. Claridge, E.J. Cussen, T.J. Prior, M.J. Rosseinsky, Acc. Chem. Res., 2005, 38, 273; i) D. Tanaka, S. Kitagawa, Chem. Mater., 2008, 20, 922; j) M.D. Allendorf, C.A. Bauer, R.K. Bhakta, R.J.T. Houk, Chem. Soc. Rev., 2009, 38, 1330; k) M. Kurmoo, Chem. Soc. Rev., 2009, 38, 1353; 1) M. Dinca, J.R. Long, Angew. Chem., Int. Ed., 2008, 47, 6766; m) M.J. Rosseinsky, Microporous Mesoporous Mater, 2004, 73, 15; n) A.N. Khlobystov, N.R Champness, C.J. Roberts, S.J.B. Tendler, C. Thompson, M. Schroder, CrystEngComm., 2002, 4, 426.

[3] a) S. Noro, S. Kitagawa, M. Yamashita, T. Wada, Chem .Commun., 2002, 222; b) R. Kitaura, G. Onoyama, H. Sakamoto, R. Matsuda, S.Noro, S. Kitagawa, Angew. Chem. Int. Ed., 2004, 43, 2684; c) S. Noro, H. Miyasaka, S. Kitagawa, T. Wada, T. Okubo,M. Yamashita, T. Mitani, Inorg. Chem., 2005, 44, 133; d) B.D. Chandler, A.P. Coté, D.T. Cramb, J.M. Hill, G.K.H. Shimizu, Chem. Commun., 2002, 1900; e) Y.-B. Dong, M.D. Smith, H.-C. zur Loye, Angew. Chem., Int. Ed., 2000, 39, 4271; f) Y.-B. Dong, M.D. Smith, H.-C. zur Loye, Inorg. Chem., 2000, 39, 1943; g) D.M. Ciurtin, M.D. Smith, H.-C. zur Loye, Chem. Commun., 2002, 74; h) L. Carlucci, G. Ciani, F. Porta, D.M. Proserpio, L. Santagostini, Angew. Chem., Int. Ed., 2002, 41, 1907; i) K.-T. Youm, S. Huh, Y.J. Park, S. Park, M.-G. Choi, M.-J.Jun, Chem.Commun., 2004, 2384; j) K.-T. Youm, M.G. Kim, J. Ko, M.-J. Jun, Angew. Chem., Int. Ed., 2006, 45, 4003; k) M. Li, L. Yuan, H. Li, J. Sun, Inorg. Chem. Comm., 2007, 10, 1281; 1) A.-L. Cheng, N. Liu, J.-Y. Zhang, E.-Q. Gao, Inorg. Chem., 2007, 46, 1034; m) S.-S. Zhang, S. Z. Zhan, M. Li, R. Peng, D. Li, Inorg. Chem., 2007, 46, 4365; n) K.S. Suslick, P. Bhyrappa, J.H. Chou, M.E. Kosal, S. Nakagaki, D.W. Smithenry, S.R. Wilson, Acc. Chem. Res. 2005, 38, 283.

[4] a) Q-D. Liu, J.-R. Li, S. Gao, B.-Q. Ma, Q.-Z. Zhou, K.-B.Yu, H. Liu, Chem. Commun. 2000, 1685; b) Y-P. Ren, L-S. Long, B-W. Mao, Y-Z. Yuan, R-B Huang, L-S. Zheng, Angew. Chem., Int. Ed., 2003, 42, 532; c) Z. He, C. He, E.Q. Gao, Z.-M. Wang, X.-F. Yang, C.-S. Liao, C.-H. Yan, Inorg. Chem., 2003, 42, 2206; d) O. Guillou, C. Daiguebonne, M. Camara, N. Kerbellec, Inorg. Chem., 2006, 45, 8468; e) Y.-G. Huang, X.-T. Wang, F.-L. Jiang, S. Gao, M.-Y Wu, Q. Gao, W. Wei, M.-C. Hong, Chem. Eur. J., 2008, 14, 10340; f) J.-X. Ma, X.-F. Huang, X.-Q. Song, L.-Q. Zhou, W.-S. Liu, Inorg. Chim. Acta 2009, 362, 3274; g) J.-X. Ma, X.-F. Huang, Y. Song, X.-Q. Song, W.-S. Liu, Inorg. Chem., 2009, 48, 6326

[5] a) S.R. Halper, S.M. Cohen, Inorg. Chem., 2005, 44, 486; b) D.L. Murphy, M.R Malachowski, C.F. Campana, S.M. Cohen, Chem. Commun., 2005, 5506; c) S.R. Halper, L. Do, J.R. Stork, S.M. Cohen, J. Am. Chem. Soc., 2006, 128, 15255.

[6] a) V.D. Vreshch, A.B. Lysenko, A.N. Chernega, J.A.K. Howard, H. Krautscheid, J. Sieler, K.V. Domasevitch, Dalton Trans., 2004, 2899; b) A.D. Burrows, K. Cassar, M.F. Mahon, J.E. Warren, Dalton Trans., 2007, 2499; c) B. Chen, F.R Fronczek, A.W. Maverick, Chem. Commun., 2003, 2166; d) B. Chen, F.R. Fronczek, A.W. Maverick, Inorg. Chem., 2004, 43, 8209.

[7] a) N.W. Ockwig, O. Delgado-Friedrichs, M. O'Keeffe, O.M. Yaghi, Acc. Chem. Res., 2005, 38, 176; b) H. Furukawa, J. Kim, N.W. Ockwig, M. O’Keeffe, O.M Yaghi, J.Am.Chem.Soc., 2008, 130, 11650; c) D.J. Tranchemontagne, J.L. Mendoza-Cortes, M. O'Keeffe, O.M. Yaghi, Chem. Soc. Rev., 2009, 38, 1257.

[8] V. Circu, T. J. K. Gibbs, L. Omnes, P. N. Horton, M. B. Hursthouse, B. W. Duncan, J. Mater. Chem., 2006, 44, 4316.

[9] J. P. Anselme, J. Org. Chem., 1967, 32, 3716.

[10] See e.g.: R.N. Hargreaves, M.R. Truter, J.Chem.Soc.A, 1969, 2282; W. Rigby, H.-B. Lee, P.M. Bailey, J.A. McCleverty, P.M. Maitlis, J.Chem.Soc.,Dalton Trans., 1979, 387; U. Kolle, J. Kossakowski, G. Raabe, Angew.Chem.,Int.Ed., 1990, 29, 773; U. Koelle, C. Rietmann, G. Raabe, Organometallics, 1997, 16
3273; H.K. Gupta, N. Rampersad, M. Stradiotto, M.J. McGlinchey, Organometallics, 2000, 19, 184; L.E. Harrington, J.F. Britten, D.W. Hughes, A.D. Bain, J.-Y. Thepot, M.J. McGlinchey, J.Organomet.Chem. , 2002, 656 243; T. Matsumoto, D.J. Taube, R.A. Periana, H. Taube, H. Yoshida, J.Am.Chem.Soc, 2000, 122, 7414; T. Matsumoto, R.A. Periana, D.J. Taube, H. Yoshida, J.Mol.Catal.A:Chem., 2002, 180, 1; S. Patra, B. Mondal, B. Sarkar, M. Niemeyer, G.K. Lahiri, Inorg.Chem., 2003, 42, 1322; J. Shono, Y. Nimura, T. Hashimoto, K. Shimizu, Chem.Lett., 2004, ,33, 1422

[11] a) V.A. Blatov, L. Carlucci, G. Ciani, D.M. Proserpio, CrystEngComm., 2004, 6 , 377; b) I. Baburin, V.A. Blatov, L. Carlucci, G. Ciani, D.M. Proserpio, J. Solid State Chem., 2005, 178, 2452.

[12] a) B. Kesanli, Y. Cui, M.R. Smith, E.W. Bittner, B.C. Bockrath, W. Lin, Angew. Chem. Int. Ed. 2005, 44, 72-75. Here the pcu description arises only if the whole polynuclear units $\left[\mathrm{Zn}_{4}\left(\mu_{4}-\mathrm{O}\right)\right]$ are considered as nodes;. b) S. Aitipamula, A. Nangia, Chem. Commun. 2005, 3159. Here the pcu description arises if a synthon description of the H-Bond is considered.

[13] a) Y.-M. Lu, Y.-Q. Lan,Y.-H. Xu, Z.-M. Su , S.-L. Li , H.-Y. Zang, G.-J. Xu, Journal of Solid State Chemistry, 2009, 182, 3105; b) L. Fan, D. Xiao, E. Wang, Y. Li, Z. Su, X Wang, J. Liu, Cryst.Growth Des., 2007, 7, 592. The pcu description arises only if the nodes are represented by polynuclear ' $\mathrm{Cd}_{2}$ ' units in ref. a) and ' $\mathrm{Cu}_{6}$ ' polynuclear units in ref. b)

[14] a) W.H.J. Watson, C.T. Lin, Inorg. Chem. 1966, 5, 1074; b) J. Fornies, R. Navarro, M. Tomas, E.P. Urriolabeitia, Organometallics 1993, 12, 940; c) K-M. Chi, K-H. Chen, S-M. Peng, G.-H. Lee, Organometallics , 1996, 15, 2575; d) E. Alonso, J. Fornies, C. Fortuno, A. Martin, A.G. Orpen, Organometallics, 2003 22, 5011; e) K. Akhbari, A. Morsali, Cryst.Growth Des., 2007, 7, 2024.

[15] a) O. Delgado Friedrichs, M. O'Keeffe and O. M. Yaghi Acta Cryst. 2003, A59, 515-525; b) A.C. Sudik, A.P.Cote, O.M. Yaghi, Inorg. Chem., 2005, 44, 2998.

[16] a) Y. Cui, H. L. Ngo, P. S. White, W. Lin, Chem. Commun. 2002, 1666; b) G. Yang, R. G. Raptis, Chem. Commun. 2004, 2058; c) Ji Hye Yoon,Sang Beom Choi,You Jin Oh,Min Jeong Seo,Young Ho Jhon,Tae-Bum Lee,Daejin Kim,Seung, Hoon Choi,Jaheon Kim Catal.Today, 2007, 120, 324; d) TzuooTsair Luo, Huang-Chun Wu, Yu-Chen Jao, Sheng-Ming Huang, Tien-Wen Tseng, Yuh-Sheng Wen, Gene-Hsiang Lee, Shie-Ming Peng, and Kuang-Lieh Lu, Angew. Chem. Int. Ed. 2009, 48, 9461 -9464 e) S. Ma, J. M. Simmons, D. Yuan, J.-R. Li, W. Weng, D. J. Liu, H.-C. Zhou, Chem. Commun., 2009, 40494051;Y. Qiu, Y. Li, G. Peng, J. Cai, L. Jin, L. Ma, H. Deng, M. Zeller, S. R. Batten Cryst.Growth Des., 2010, 10, 1332-1340.

[17] S. Horike, S. Shimomura, S. Kitagawa, Nat. Chem. 2009, 1, 695.

[18] We have characterized by single crystal X-ray diffraction eight MOFs with $\mathrm{Zn}$ (Table 1 and S5) having the same network structure in which the anions populate the channels (free or only weakly coordinated to $\mathrm{Ag}$ ions) that exhibit $\boldsymbol{c} / \boldsymbol{a}$ values from 1.11 to 1.04 and volumes from 3239 to $3550 \mathrm{~A}^{3}$ in response to the total channel content (not only due to the anion dimensions). We have observed variations of the channels for which the shrinkage, corresponding to reduction of the free voids, implies an increase of the $\boldsymbol{c} / \boldsymbol{a}$ ratio. This seems a possible deformation path that needs to be fully confirmed on the same compound in the next future.

[19] A. L. Spek, J. Appl. Crystallogr., 2003; 36: 7-13.

[20] S. Kitagawa, S. Noro, T. Nakamura, Chem. Commun. 2006, 701.

[21] J.-P. Zhang, S. Horike, S. Kitagawa Angew. Chem., Int. Ed., 2007, 46, 889.

[22] Due to the very poor solubility of these compounds in the common solvents it was not possible to establish the anion contents by direct solution NMR analyses. We have tried to quantify the amount of $\mathrm{BF}_{4}{ }^{-}$anions contained in the channels of the corresponding polymers by ${ }^{19} \mathrm{~F}-\mathrm{NMR}$ on solutions obtained after exchange of $\mathrm{BF}_{4}^{-}$with $\mathrm{ClO}_{4}^{-}$(see text below), using trifluorotoluene as standard. The experimental amounts of anions resulted in an almost correct ratio. Elemental analyses of the crystals attempted with SEM have only shown that the content of the channels is very inconstant and can change from a crystal to another, and also inside the same crystal from a region to another one. So we can conclude that the composition of the channels is very changeable.

[23] a) To confirm the nature of the desolvation/resolvation process few single crystals of compound $\mathbf{4 b}$ were desolvated in an oven at $100^{\circ} \mathrm{C}$ for $30 \mathrm{~min}$ (see TGA in Fig. S3) and then left in the air at room temperature. After these processes the single crystallinity is maintained and the X-ray single crystal diffraction at room temperature shows cell parameters of $a=b=15.72(5) ; c=$ 6.19(5); V = 3476(12)

b) Few single crystals of compound $\mathbf{4 b}$ were suspended in a saturated methanolic solution of $\mathrm{NaClO}_{4}$ and left to stand for $3 \mathrm{~h}$ under moderate shaking. The crystals observed under the optical microscope maintain their shape (see Fig. S13) and the IR spectrum on a portion of this sample shows that $\mathrm{ClO}_{4}^{-}$has exchanged $\mathrm{BF}_{4}^{-}$. X-ray single crystal diffraction at room temperature for few selected crystals reveals that the single crystallinity is preserved and the cell parameters are very similar to the original ones for 4a, e.g. $a=b=15.53(6) ; c=$ 16.28(6); $\mathrm{V}=3400(12)$. The same results are obtained also after leaving the crystals in a saturated methanolic solution of $\mathrm{NaClO}_{4}$ for $24 \mathrm{~h}$.

[24] a) S. Kitagawa and M. Kondo, Bull. Chem. Soc. Jpn., 1998, 71, 1739; b) K Uemura, S. Kitagawa, M. Kondo, K. Fukui, R. Kitaura, H.-O. Chang, T Mizutani, Chem. Eur. J., 2002, 8, 3587-3600; c) S. Kitagawa, R. Matsuda, Coord. Chem Rev., 2007, 251,2490 
[25] C. Jiang, Y.-S. Wen, L.-K. Liu, T. S. A. Hor, Y. K. Yan, Organometallics 1998, $17,173-181$

[26] J. J. Brunet, F. B. Kindela, D. Neibecker, S. A. Wander, M. Y. Darensbourg, Inorganic Syntheses 1992, 29, 151-156.

[27] W. C. Fernelius, J. J. Burbage, Inorganic Synthesis, 1946, 2, 227-228.

[28] G. M. Sheldrick, SADABS: Siemens Area Detector Absorption Correction Software, University of Goettingen, Germany, 1996.

[29] A. Altomare, M. C. Burla, M. Camalli, G. Cascarano, C. Giacovazzo, A. Guagliardi, A. G. Moliterni, G. Polidori, R. Spagna, J. Appl.Crystallogr. 1999; 32, 115-119.

[30] Sheldrick GM, SHELX-97, University of Goettingen, Germany, 1997.

[31] L. J. Farrugia, Appl. Crystallogr., 1999; 32: 837-837

[32] P. Van der Sluis, A. L. Spek, Acta Crystallogr., Sect. A: Found.Crystallogr., 1990, 46, 194-201.

[33] L. J. Farrugia, J. Appl. Cryst. 1997, 30, 565

[34] V. A. Blatov, IUCr, Comput. Comm. Newslett., 2006, 7, 4, see also http : //www.topos.ssu.samara.ru.

[35] C. F. Macrae, P. R. Edgington, P. McCabe, E. Pidcock, G. P. Shields, R. Taylor, M. Towler, J. van de Streek, J. Appl. Cryst. 2006, 39, 453-457.

Received: ((will be filled in by the editorial staff))

Revised: ((will be filled in by the editorial staff)) Published online: ((will be filled in by the editorial staff)) 
Remarkably always the same framework!

Lucia Carlucci, * Gianfranco Ciani, Simona Maggini, Davide M.

Proserpio and Marco Visconti ............ Page - Page

Heterometallic Modular Metal-

Organic 3D Frameworks

Assembled via New Tris-

$\beta$-Diketonate Metalloligands:

Nanoporous Materials for Anion

Exchange and Scaffolding of

Selected Anionic Guests.
Novel tris-chelate $\beta$-diketonate metalloligands were reacted with $\mathrm{AgX}$ salts to give more than twenty heterometallic networks

$\left[\mathrm{M}^{\mathrm{III}} \mathrm{L}_{3} \mathrm{Ag}_{3}\right] \mathrm{X}_{3}$ and $\left[\mathrm{M}^{\mathrm{IIL}}{ }_{3} \mathrm{Ag}_{3}\right] \mathrm{X}_{2}$ all exhibiting the same framework structure, in spite of the different metal nodes, ionic charges and $\mathrm{X}^{-}$ counteranions. These nanoporous networks (6-fold interpenetrated pcu) display large 1D channels containing the anions easily exchanged with many selected anionic species, including coordination complexes and organometallic anions (see figure). 


\section{Heterometallic Modular Metal-Organic 3D Frameworks Assembled via New Tris- $\beta$-Diketonate Metalloligands: Nanoporous Materials for Anion Exchange and Scaffolding of Selected Anionic Guests.}

Lucia Carlucci, ${ }^{*}$ Gianfranco Ciani, Simona Maggini, Davide M. Proserpio and Marco Visconti

Università degli Studi di Milano, Dipartimento di Chimica Strutturale e Stereochimica Inorganica, Via G. Venezian 21, 20133 Milano, Italy.

Supporting Information

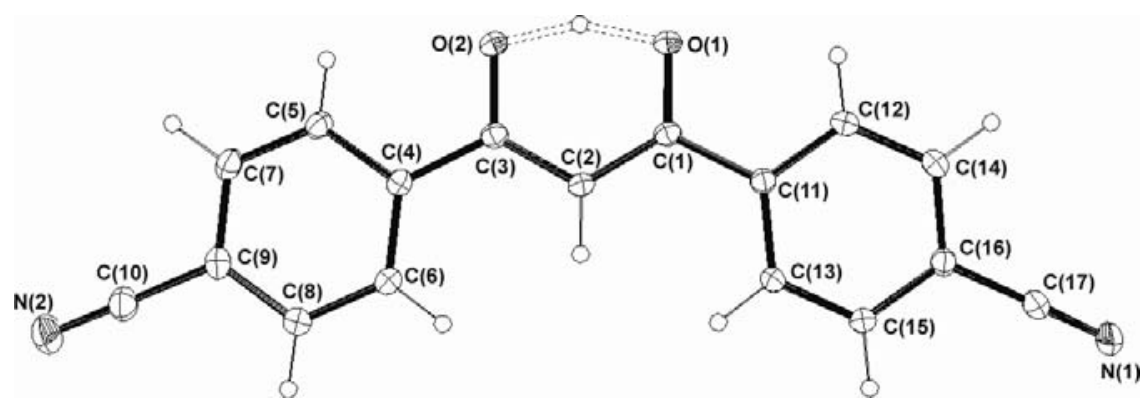

Figure S1. Molecular structure of 1,3-bis(4'-cyano-phenyl)-1,3-propanedione (HL). Selected bond parameters: $\mathrm{C}(1)-\mathrm{C}(2) 1.404(2), \mathrm{C}(1)-\mathrm{O}(1)$ 1.279(1), C(1)-C(11) 1.486(1), C(2)-C(3) 1.400(1), $\mathrm{C}(3)-\mathrm{O}(2) 1.290(1), \mathrm{C}(3)-\mathrm{C}(4)$ 1.482(2), C(9)-C(10) 1.443(2), C(10)-N(2) 1.145(2), C(16)-C(17) 1.441(2), C(17)-N(1) 1.141(2), O(1)-H 1.27(3), O(2)-H 1.24(3), O(1)..O(2) $2.44 \AA$; C(1)-C(2)$\mathrm{C}(3)$ 119.5(1), O(1)-C(1)-C(2) 121.0(1), O(1)-C(1)-C(11) 116.1(1), C(2)-C(1)-C(11) 122.9(1), $\mathrm{O}(2)-\mathrm{C}(3)-\mathrm{C}(2) 120.5(1), \mathrm{O}(2)-\mathrm{C}(3)-\mathrm{C}(4) 115.8(1), \mathrm{C}(2)-\mathrm{C}(3)-\mathrm{C}(4) 123.7(1)^{\circ}$. 


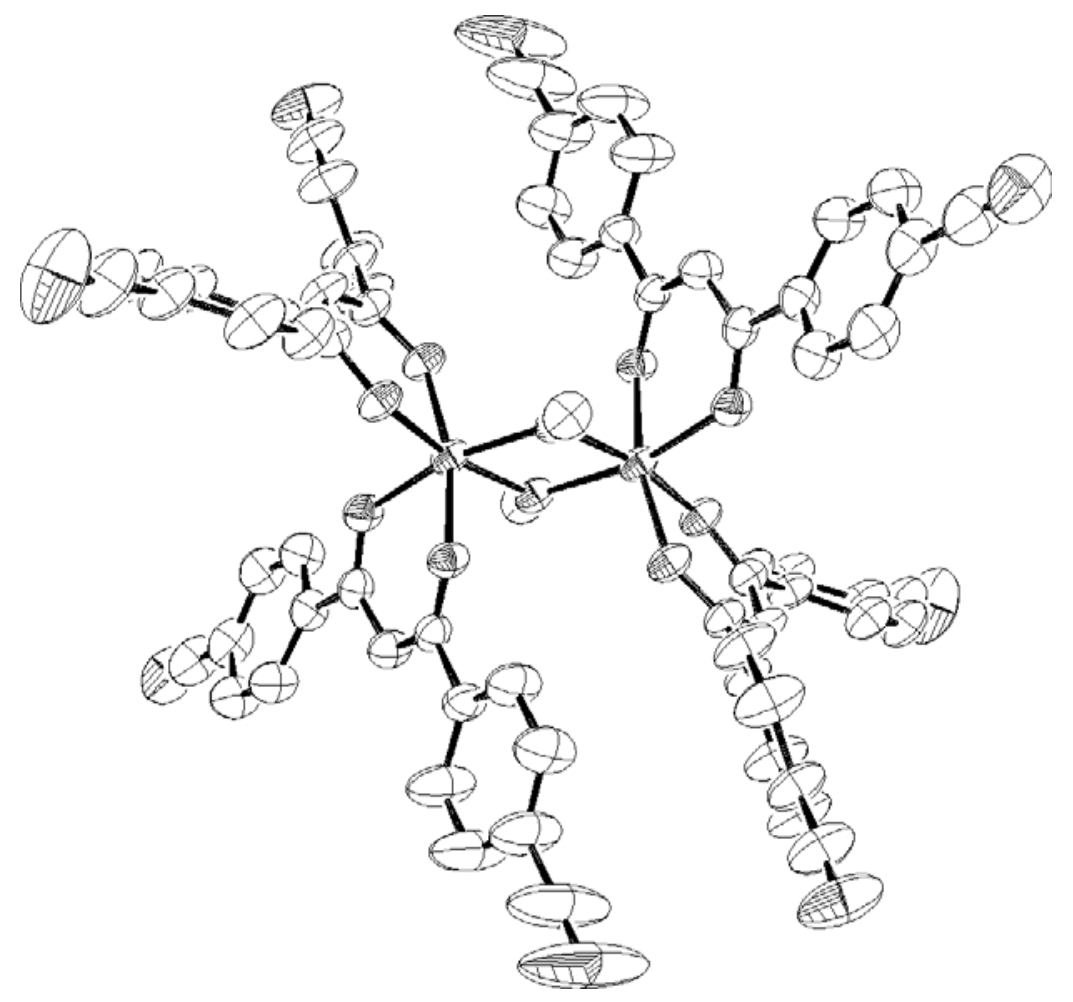

Figure S2. Molecular structure of the centrosymmetric dinuclear species $\left[\mathrm{Fe}_{2}(\mu-\mathrm{OMe})\right]_{2}$. Crystal data: $\mathrm{C}_{70} \mathrm{H}_{42} \mathrm{Fe}_{2} \mathrm{~N}_{8} \mathrm{O}_{10}, \mathrm{Fw}=1266.82$, Monoclinic, space group $\mathrm{P} 2{ }_{1} / \mathrm{c}($ No. 14$), a=9.511(2) \AA, b=$ 28.803(5) $\AA, c=14.351(2) \AA, \beta=107.060(2)^{\circ}, \mathrm{V}=3759(1) \AA^{3}, \mathrm{Z}=2, \mathrm{D}_{\text {calcd }}=1.119 \mathrm{~g} \mathrm{~cm}^{-3}, \mathrm{~T}=$ $150(2) \mathrm{K}$. The crystal is unstable in air; it was collected under mineral oil. The structure contains disordered solvents. Because it was not possible to refine a consistent disordered model, their contribution was subtracted from the observed structure factors according to the BYPASS procedure, as implemented in PLATON (A.L. Spek, J. Appl. Cryst., 2003, 36, 7). Least-squares refinement on $\mathrm{F}^{2}$ based on 5038 reflections with $I>4 \sigma(I)$ and 406 parameters using 0 restraints led to final $R 1=0.0582$ and $w R 2=0.1503$. The $\mathrm{R}$ before squeeze was $\mathrm{R} 1=0.1882$ for $5038 \mathrm{Fo}>$ $4 \sigma(\mathrm{Fo})$. The two Fe(III) atoms, placed at a distance of $3.085 \AA$, show distorted octahedral coordination geometry, the $\mathrm{FeO}_{6}$ chromophore presenting similar $\mathrm{Fe}-\mathrm{O}$ bond distances in the range 1.967(2)- 2.003(2) A and $\mathrm{O}-\mathrm{Fe}-\mathrm{O}$ cisoid and transoid angles in the ranges $76.96(8)-103.56(8)^{\circ}$ and $165.96(8)-168.12(8)^{\circ}$, respectively. 


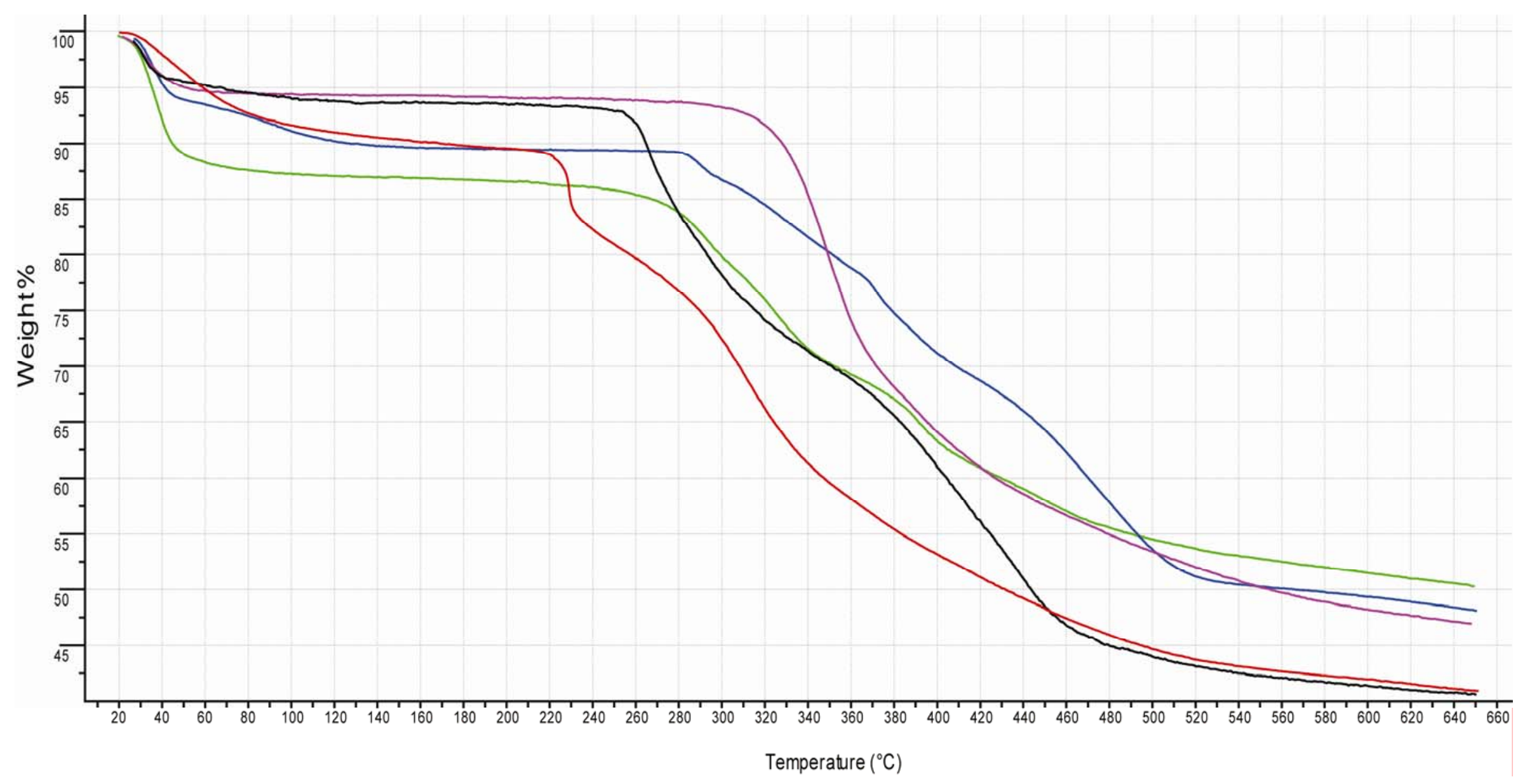

Figure S3 - TG traces in the range $30-650{ }^{\circ} \mathrm{C}$ for compounds: $\left[\mathrm{ZnL}_{3} \mathrm{Ag}_{3}\right]\left(\mathrm{BF}_{4}\right)_{2}$ (4b, green), $\left[\mathrm{ZnL}_{3} \mathrm{Ag}_{3}\right]\left(\mathrm{ClO}_{4}\right)_{2}\left(4 \mathbf{c}\right.$, violet), $\left[\mathrm{ZnL}_{3} \mathrm{Ag}_{3}\right]\left(\mathrm{SO}_{3} \mathrm{CF}_{3}\right)_{2}$ (4d, blue), $\left[\mathrm{ZnL}_{3} \mathrm{Ag}_{3}\right]\left(\mathrm{PF}_{6}\right)_{2}$ (4e, black), $\left[\mathrm{ZnL}_{3} \mathrm{Ag}_{3}\right]\left(\mathrm{NO}_{3}\right)_{2}$ (4h, red). 


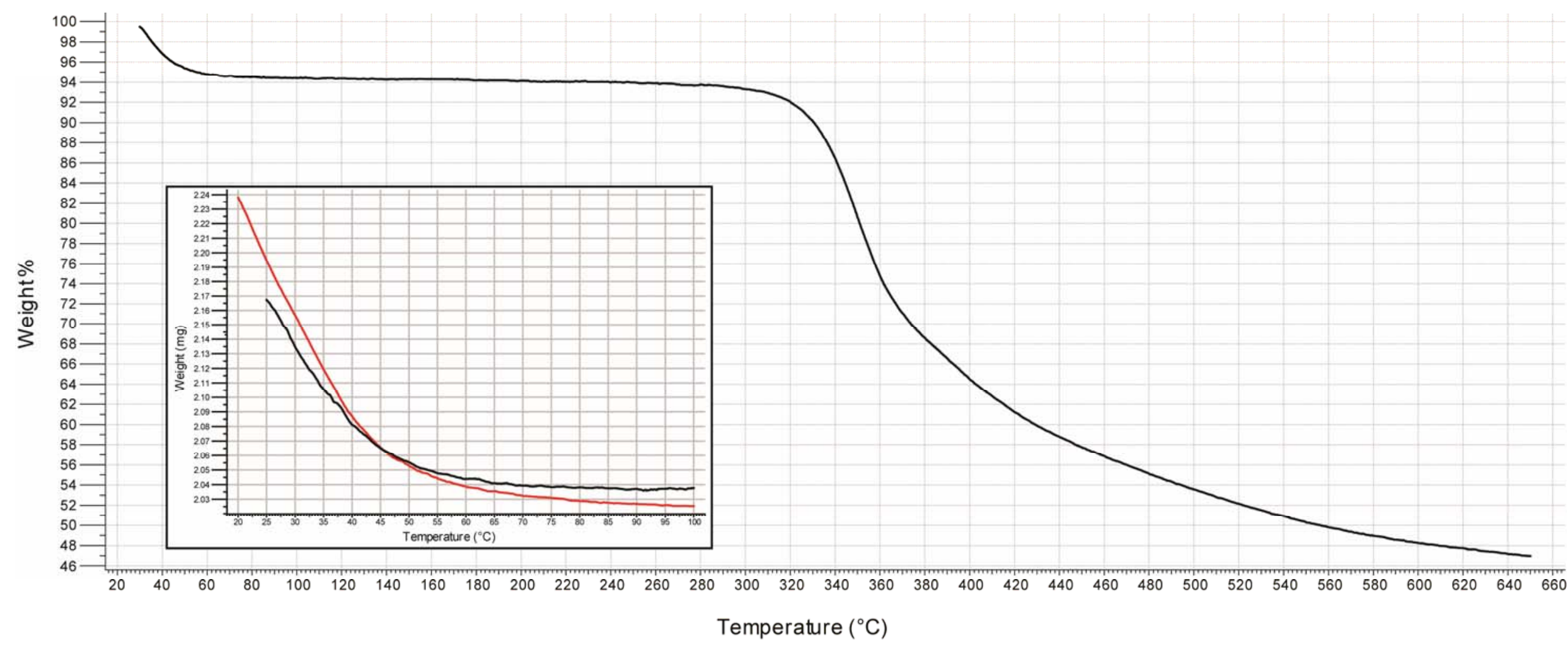

Figure S4 - TG trace for compound $\left[\mathrm{ZnL}_{3} \mathrm{Ag}_{3}\right]\left(\mathrm{ClO}_{4}\right)_{2}(4 \mathrm{c})$ in the range $30-650{ }^{\circ} \mathrm{C}$. In the inset in red the de-solvation trace in the range $30-100^{\circ} \mathrm{C}$ for a sample of $4 \mathbf{c}$ obtained from the mother liquor. In black the de-solvation trace for the previous de-solvated sample left in the air. 


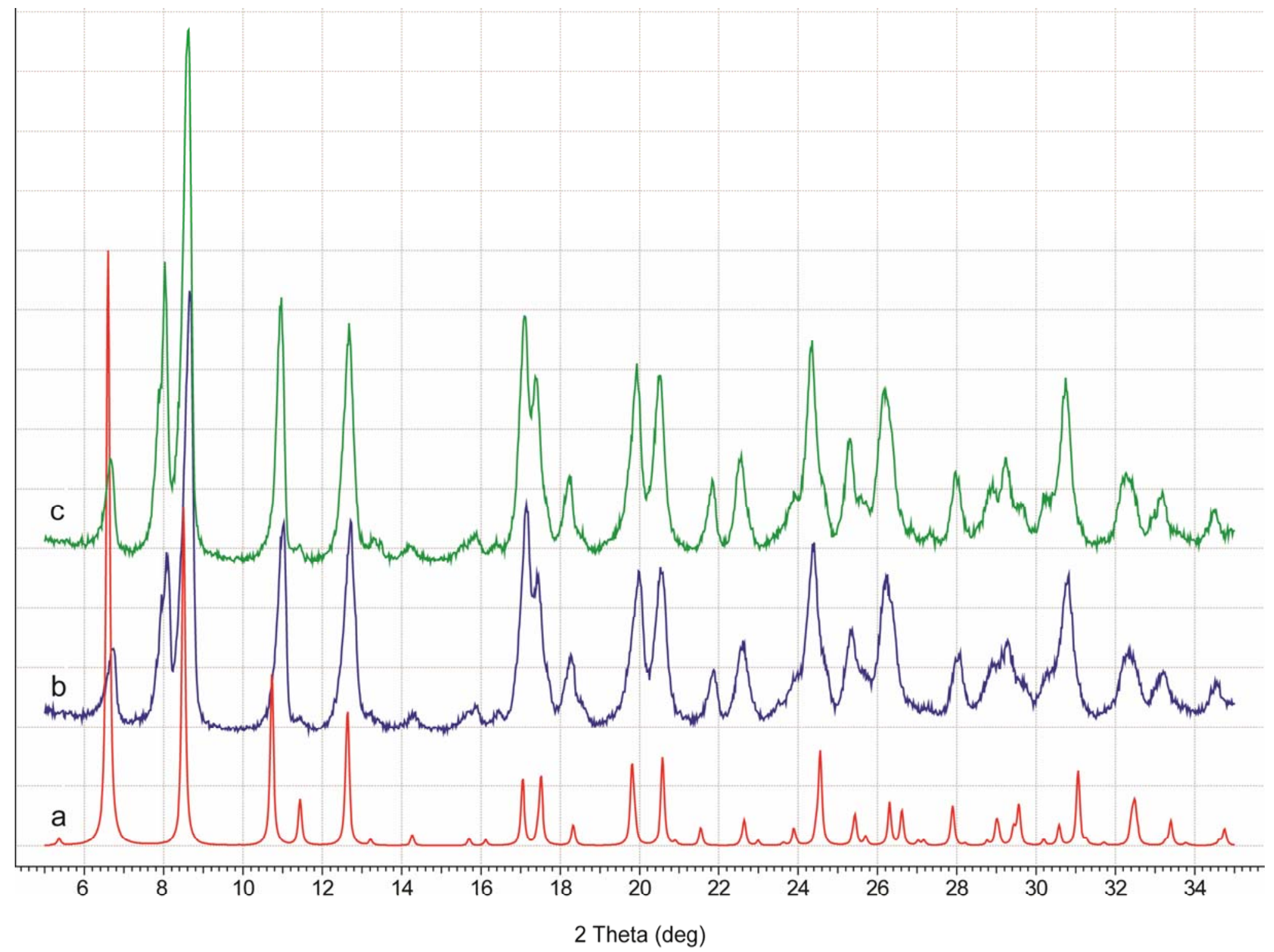

Figure S5 - Calculated XRPD pattern for compound 4c (a); experimental XRPD pattern for compound 4c (b); experimental XRPD pattern for compound $\mathbf{4 c}$ desolvated at $100{ }^{\circ} \mathrm{C}$ and left in the air. 


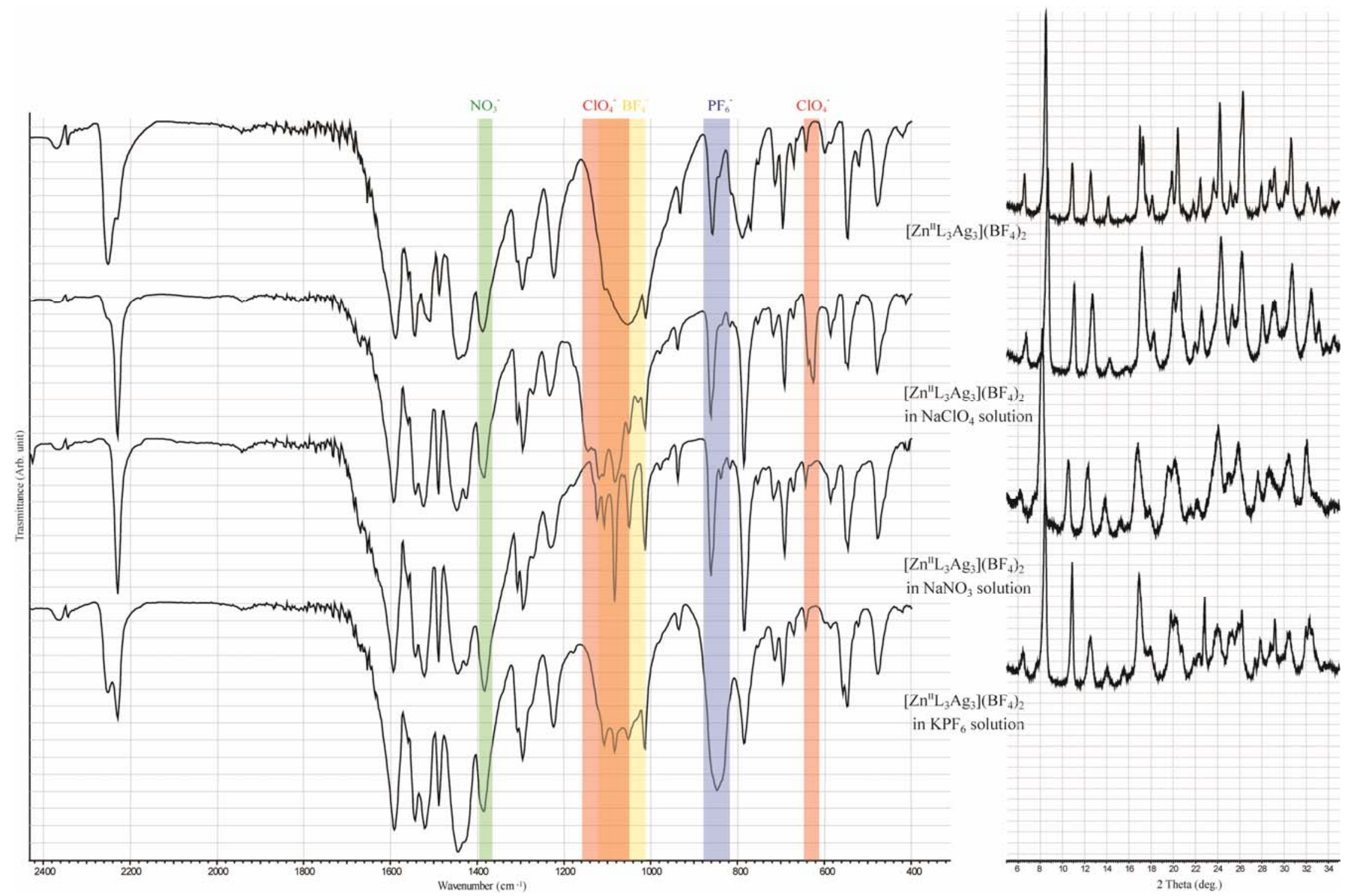

Figure S6 - IR spectra (left) and XRPD patterns (right) of samples of compound $\left[\mathrm{ZnL}_{3} \mathrm{Ag}_{3}\right]\left(\mathrm{BF}_{4}\right)_{2}(\mathbf{4 b})$ treated with $\mathrm{NaClO}_{4}, \mathrm{NaNO}_{3}$ and $\mathrm{KPF}_{6}$ (from top to bottom). 


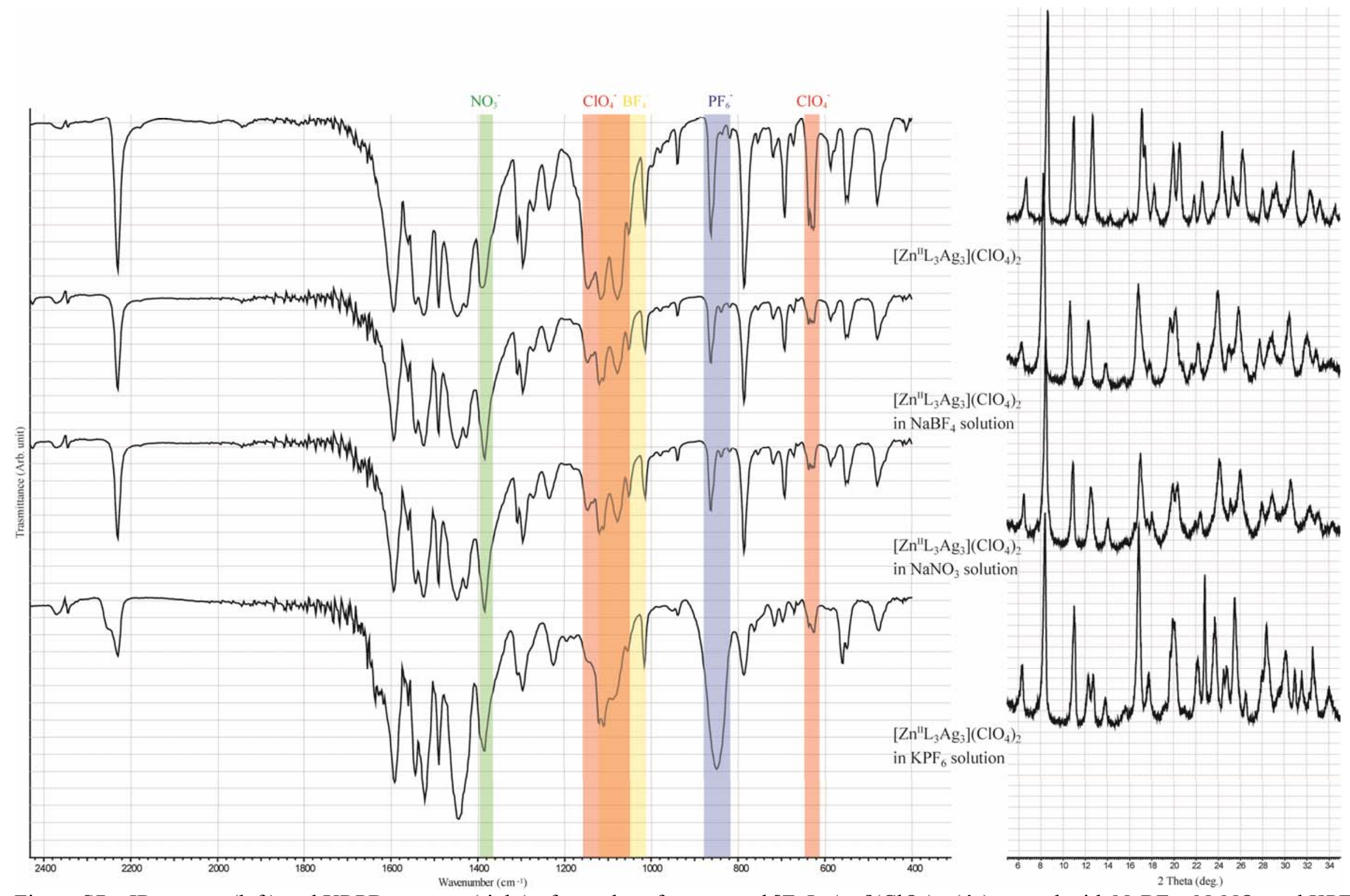

Figure S7 - IR spectra (left) and XRPD patterns (right) of samples of compound $\left[\mathrm{ZnL}_{3} \mathrm{Ag}_{3}\right]\left(\mathrm{ClO}_{4}\right)_{2}(4 \mathrm{c})$ treated with $\mathrm{NaBF}_{4}, \mathrm{NaNO}_{3}$ and $\mathrm{KPF}_{6}$ (from top to bottom). 


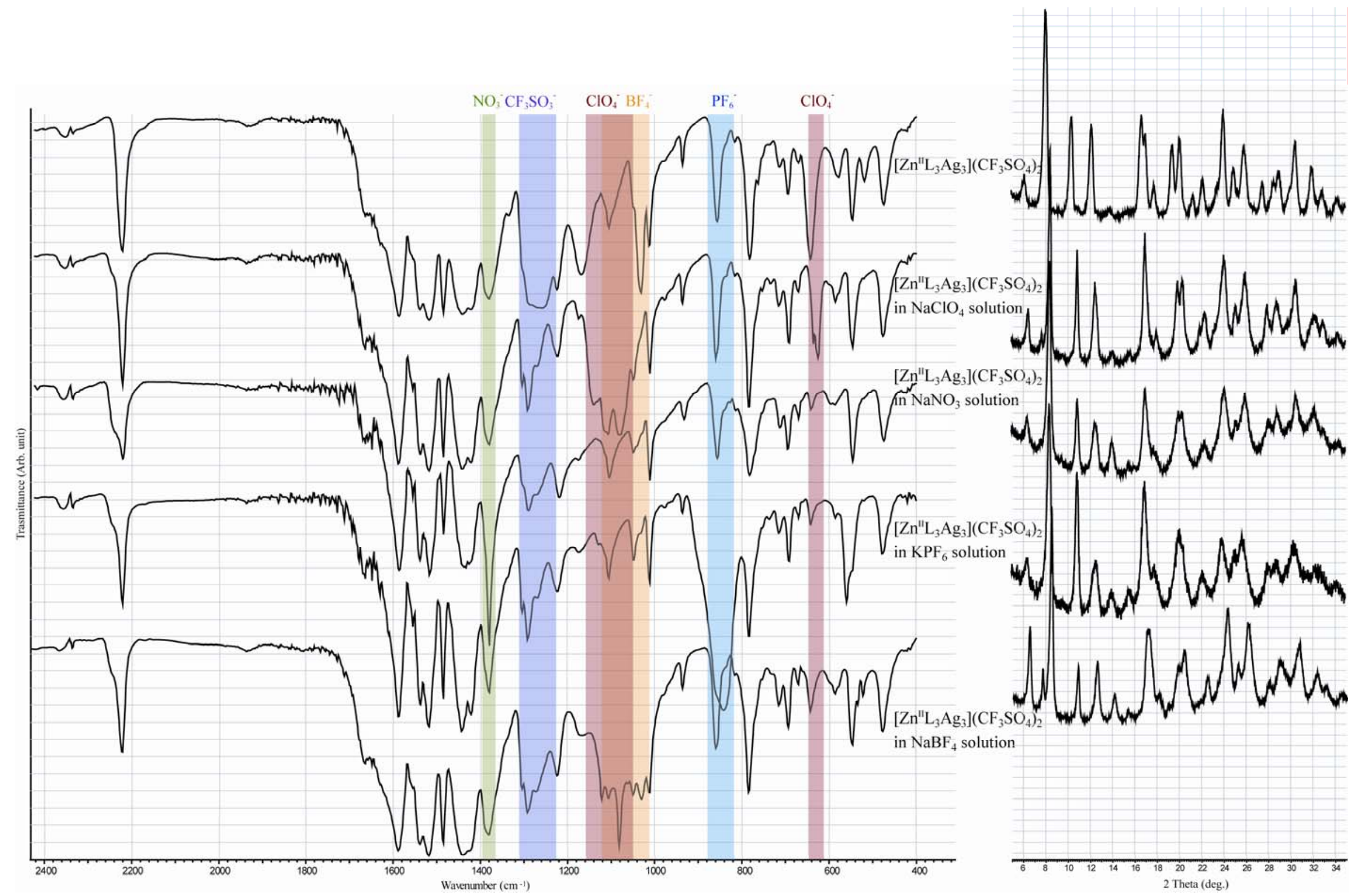

Figure S8 - IR spectra (left) and XRPD patterns (right) of samples of compound $\left[\mathrm{ZnL}_{3} \mathrm{Ag}_{3}\right]\left(\mathrm{CF}_{3} \mathrm{SO}_{3}\right)_{2}(\mathbf{4 d})$ treated with $\mathrm{NaClO}_{4}, \mathrm{NaNO}_{3}, \mathrm{KPF}_{6}$ and $\mathrm{NaBF}_{4}$ (from top to bottom). 


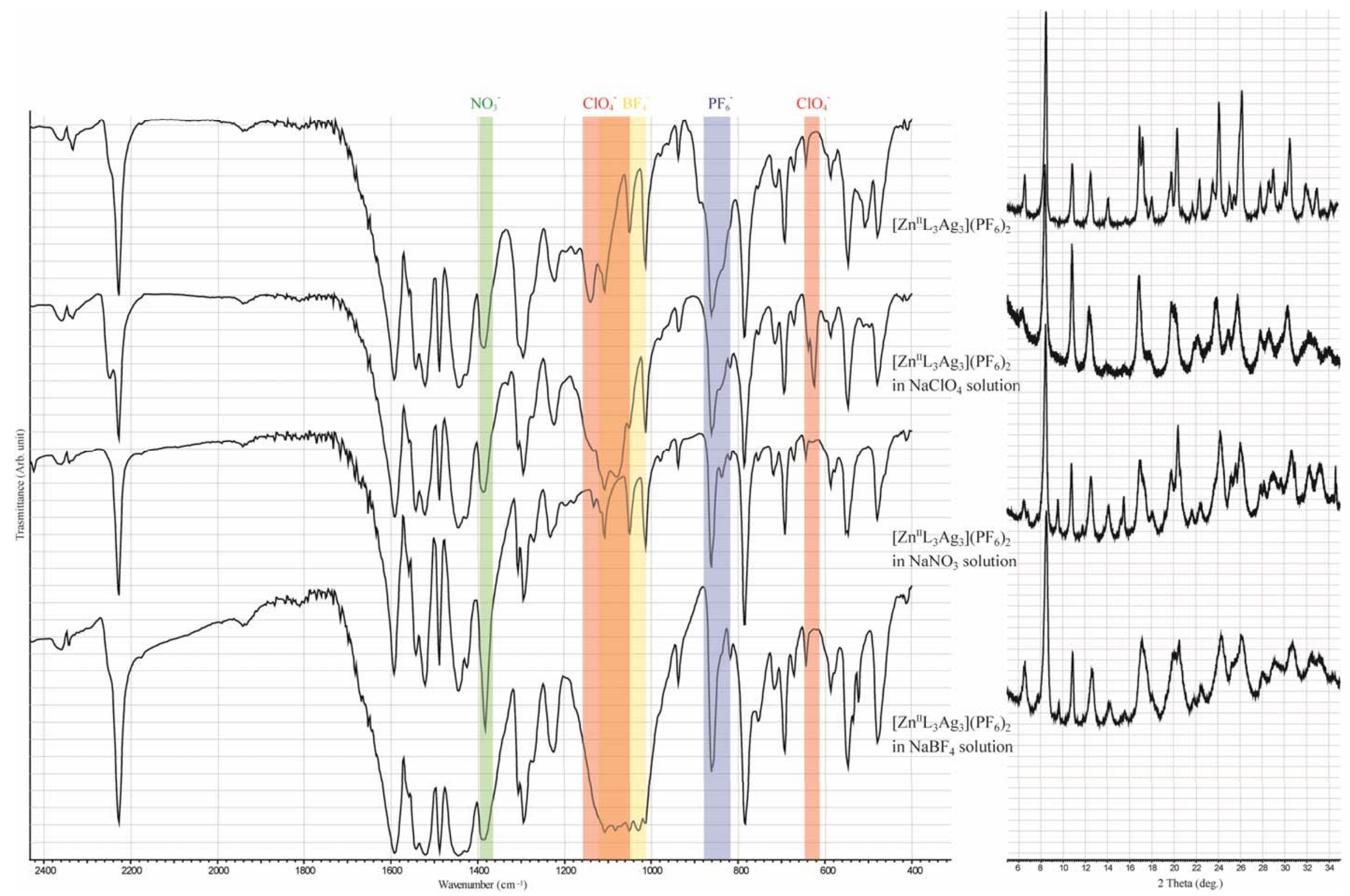

Figure S9 - IR spectra (left) and XRPD patterns (right) of samples of compound $\left[\mathrm{ZnL}_{3} \mathrm{Ag}_{3}\right]\left(\mathrm{PF}_{6}\right)_{2}(\mathbf{4 e})$ treated with $\mathrm{NaClO}_{4}, \mathrm{NaNO}_{3}$, and $\mathrm{NaBF}_{4}$ (from top to bottom). 


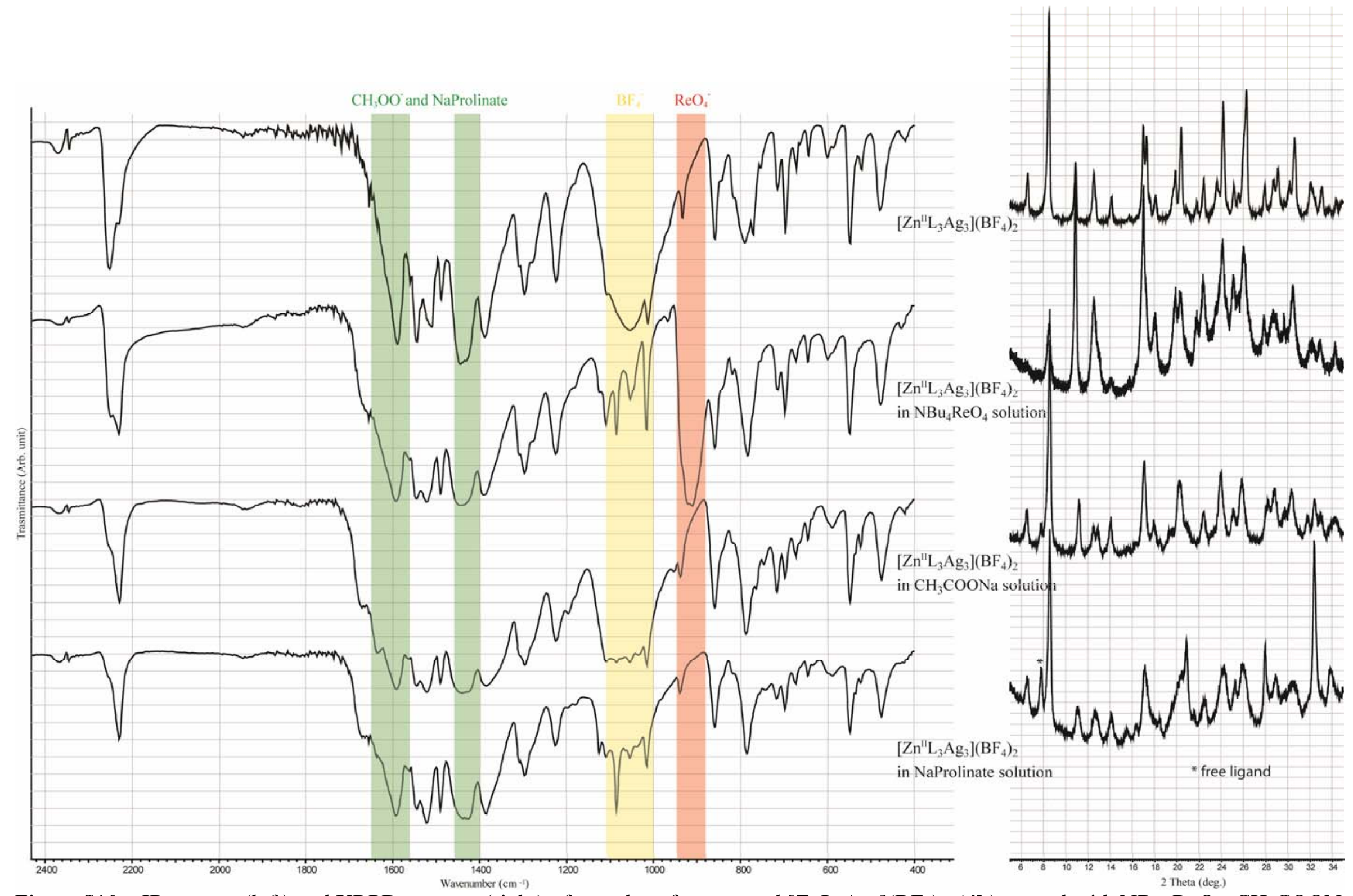

Figure S10 - IR spectra (left) and XRPD patterns (right) of samples of compound $\left[\mathrm{ZnL}_{3} \mathrm{Ag}_{3}\right]\left(\mathrm{BF}_{4}\right)_{2}(\mathbf{4 b})$ treated with $\mathrm{NBu}_{4} \mathrm{ReO}_{4}, \mathrm{CH}_{3} \mathrm{COONa}$, and sodium prolinate (from top to bottom). 


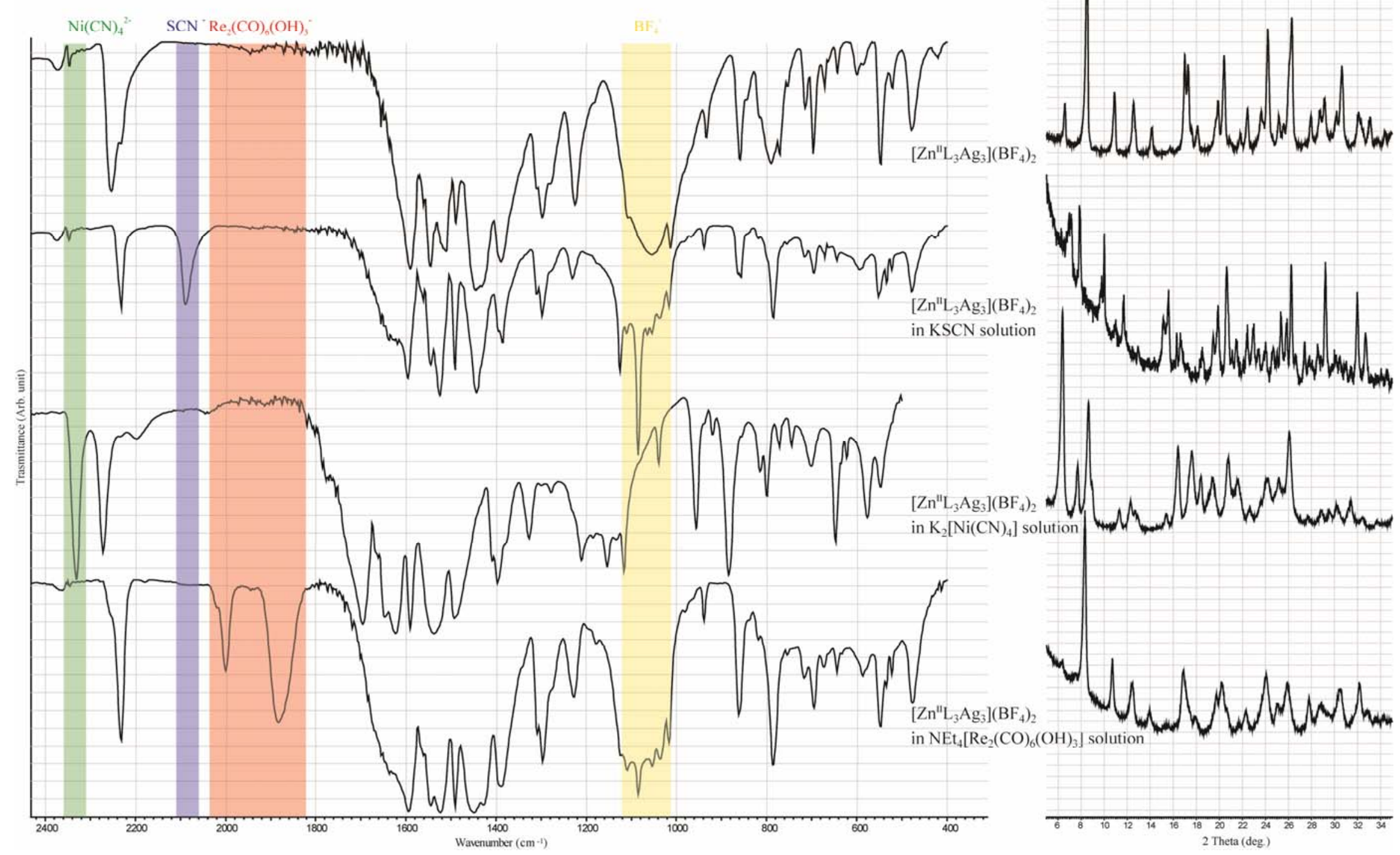

Figure S11 - IR spectra (left) and XRPD patterns (right) of samples of compound $\left[\mathrm{ZnL}_{3} \mathrm{Ag}_{3}\right]\left(\mathrm{BF}_{4}\right)_{2}(\mathbf{4 b})$ treated with $\mathrm{KSCN}, \mathrm{K}_{2}\left[\mathrm{Ni}(\mathrm{CN})_{4}\right]$, $\mathrm{NEt}_{4}\left[\operatorname{Re}_{2}(\mathrm{CO})_{6}(\mathrm{OH})_{3}\right]$ (from top to bottom). 
Table S1: Crystallographic details for HL and for compounds 1b, 2b-d, 2d'

\begin{tabular}{|c|c|c|c|c|c|c|}
\hline & HL & 1b·3acetone & $2 \mathbf{b} \cdot \mathbf{T H F}$ & $2 c$ & $2 d$ & $2 d^{\prime}$ \\
\hline Formula & $\mathrm{C}_{17} \mathrm{H}_{10} \mathrm{~N}_{2} \mathrm{O}_{2}$ & $\mathrm{C}_{60} \mathrm{H}_{45} \mathrm{CoN}_{6} \mathrm{O}_{9}$ & $\mathrm{C}_{63} \mathrm{H}_{55} \mathrm{CoN}_{7} \mathrm{O}_{7}$ & $\mathrm{C}_{60} \mathrm{H}_{49} \mathrm{Cl}_{2} \mathrm{~N}_{7} \mathrm{O}_{6} \mathrm{Zn}$ & $\mathrm{C}_{60} \mathrm{H}_{49} \mathrm{CdCl}_{2} \mathrm{~N}_{7} \mathrm{O}_{6}$ & $\mathrm{C}_{87} \mathrm{H}_{57} \mathrm{CdN}_{7} \mathrm{O}_{6} \mathrm{P}_{2}$ \\
\hline $\mathbf{M}$ & 274.27 & 1052.95 & 1081.07 & 1100.33 & 1147.36 & 1470.74 \\
\hline System & Orthorhombic & Monoclinic & Triclinic & Triclinic & Triclinic & Triclinic \\
\hline Space group & Pbcn (No.60) & C2/c (No.15) & P-1 (No.2) & P-1 (No.2) & P-1 (No.2) & P-1 (No.2) \\
\hline$a / \AA ̊$ & $13.155(1)$ & $6.567(1)$ & $11.270(1)$ & $11.3450(8)$ & $11.554(1)$ & $12.125(1)$ \\
\hline$b / \AA ̊ A$ & $12.526(1)$ & $30.830(6)$ & $14.871(2)$ & $14.841(1)$ & $14.637(1)$ & $17.514(2)$ \\
\hline$c / \AA ̊$ & $16.388(1)$ & $25.154(5)$ & $17.397(2)$ & $17.347(1)$ & $17.517(2)$ & $18.450(2)$ \\
\hline$\alpha /^{\circ}$ & 90 & 90.00 & $97.684(2)$ & $97.764(1)$ & 97.991(1) & $104.471(1)$ \\
\hline$\beta /^{\circ}$ & 90 & $91.758(3)$ & $103.936(2)$ & $103.748(1)$ & $103.712(1)$ & $97.126(1)$ \\
\hline$\gamma /{ }^{\circ}$ & 90 & 90.00 & $97.850(2)$ & $97.807(1)$ & $97.808(1)$ & $103.971(1)$ \\
\hline $\mathbf{U}, \AA^{3}$ & $2700.5(4)$ & $5090(2)$ & $2761.0(6)$ & $2767.9(3)$ & $2805.8(5)$ & $3609.9(6)$ \\
\hline $\mathbf{Z}$ & 8 & 4 & 2 & 2 & 2 & 2 \\
\hline Density $/ \mathrm{g} \mathrm{cm}^{-3}$ & 1.349 & 1.374 & 1.300 & 1.320 & 1.358 & 1.353 \\
\hline Temperature, K & $150(2)$ & $150(2)$ & $293(2)$ & 293(2) & $293(2)$ & 293(2) \\
\hline$\mu(\mathbf{M o}-\mathbf{K} \alpha) / \mathbf{m m}^{-1}$ & 0.091 & 0.404 & 0.372 & 0.597 & 0.541 & 0.408 \\
\hline Reflections collected & 46736 & 30223 & 26650 & 51576 & 53088 & 62771 \\
\hline $\begin{array}{l}\text { Indep.refls, } \\
\text { R(int) }\end{array}$ & $\begin{array}{l}3643, \\
0.0297\end{array}$ & $\begin{array}{l}4489 \\
0.1838\end{array}$ & $\begin{array}{l}9710, \\
0.0642\end{array}$ & $\begin{array}{l}14343, \\
0.0384\end{array}$ & $\begin{array}{l}14685 \\
0.0449\end{array}$ & $\begin{array}{l}16936 \\
0.1053\end{array}$ \\
\hline Crystal decay,\% & 0 & 24 & 0 & 0 & 0 & 0 \\
\hline Observed $\left[F_{0}>4 \sigma(F o)\right]$ & 3024 & 2540 & 4521 & 8633 & 9515 & 7866 \\
\hline Data/restr./param. & $3643 / 0 / 230$ & $4489 / 0 / 347$ & $9710 / 126 / 724$ & $14343 / 1 / 685$ & $14685 / 0 / 685$ & $16936 / 6 / 965$ \\
\hline $\mathrm{R} 1[\mathrm{Fo}>4 \sigma(\mathrm{Fo})]$ & 0.0428 & 0.0621 & 0.0610 & 0.0601 & 0.0508 & 0.0634 \\
\hline wR2(all data) & 0.1209 & 0.1945 & 0.1889 & 0.2009 & 0.1392 & 0.1828 \\
\hline
\end{tabular}


Table S2: Selected bond distances and angles for the metalloligands $\mathbf{1 b}, \mathbf{2 b}-\mathbf{d}$ and $\mathbf{2 d}$.

\begin{tabular}{|l|l|}
\hline \multicolumn{2}{|c|}{ 1b } \\
\hline \multicolumn{2}{|c|}{ Bond distance $(\AA)$} \\
\hline $\mathrm{Co}(1)-\mathrm{O}(1)$ & $1.892(3)$ \\
\hline $\mathrm{Co}(1)-\mathrm{O}(2)$ & $1.886(3)$ \\
\hline $\mathrm{Co}(1)-\mathrm{O}(3) \quad 1.883(3)$ \\
\hline \multicolumn{2}{|c|}{ Angle $\left(^{\circ}\right)$} \\
\hline $\mathrm{O}(1)-\mathrm{Co}(1)-\mathrm{O}(1) \#$ & $96.8(2)$ \\
\hline $\mathrm{O}(1)-\mathrm{Co}(1)-\mathrm{O}(2)$ & $88.8(1)$ \\
\hline $\mathrm{O}(1)-\mathrm{Co}(1)-\mathrm{O}(2) \#$ & $87.3(1)$ \\
\hline $\mathrm{O}(1)-\mathrm{Co}(1)-\mathrm{O}(3)$ & $87.5(1)$ \\
\hline $\mathrm{O}(1)-\mathrm{Co}(1)-\mathrm{O}(3) \#$ & $174.5(1)$ \\
\hline $\mathrm{O}(2)-\mathrm{Co}(1)-\mathrm{O}(3)$ & $96.2(1)$ \\
\hline $\mathrm{O}(2)-\mathrm{Co}(1)-\mathrm{O}(2) \#$ & $174.2(2)$ \\
\hline $\mathrm{O}(2)-\mathrm{Co}(1)-\mathrm{O}(3) \#$ & $87.9(1)$ \\
\hline $\mathrm{O}(3)-\mathrm{Co}(1)-\mathrm{O}(3) \#$ & $88.4(2)$ \\
\hline$\#=-\mathrm{x}+2, \mathrm{y},-\mathrm{z}+3 / 2$ &
\end{tabular}

\begin{tabular}{|c|c|}
\hline \multicolumn{2}{|c|}{ 2c } \\
\hline \multicolumn{2}{|c|}{ Bond distance $(\AA)$} \\
\hline $\mathrm{Zn}(1)-\mathrm{O}(1)$ & $2.090(2)$ \\
\hline $\mathrm{Zn}(1)-\mathrm{O}(2)$ & $2.081(2)$ \\
\hline $\mathrm{Zn}(1)-\mathrm{O}(3)$ & $2.067(2)$ \\
\hline $\mathrm{Zn}(1)-\mathrm{O}(4)$ & $2.119(2)$ \\
\hline $\mathrm{Zn}(1)-\mathrm{O}(5)$ & $2.102(2)$ \\
\hline $\mathrm{Zn}(1)-\mathrm{O}(6)$ & $2.054(2)$ \\
\hline \multicolumn{2}{|c|}{ Angle $\left(^{\circ}\right)$} \\
\hline $\mathrm{O}(1)-\mathrm{Zn}(1)-\mathrm{O}(2)$ & $84.84(9)$ \\
\hline $\mathrm{O}(1)-\mathrm{Zn}(1)-\mathrm{O}(3)$ & $171.31(9)$ \\
\hline $\mathrm{O}(1)-\mathrm{Zn}(1)-\mathrm{O}(4)$ & $90.93(9)$ \\
\hline $\mathrm{O}(1)-\mathrm{Zn}(1)-\mathrm{O}(5)$ & $94.81(9)$ \\
\hline $\mathrm{O}(1)-\mathrm{Zn}(1)-\mathrm{O}(6)$ & $85.99(9)$ \\
\hline $\mathrm{O}(2)-\mathrm{Zn}(1)-\mathrm{O}(3)$ & $87.12(8)$ \\
\hline $\mathrm{O}(2)-\mathrm{Zn}(1)-\mathrm{O}(4)$ & $91.47(9)$ \\
\hline $\mathrm{O}(2)-\mathrm{Zn}(1)-\mathrm{O}(5)$ & $92.34(9)$ \\
\hline $\mathrm{O}(2)-\mathrm{Zn}(1)-\mathrm{O}(6)$ & $170.69(9)$ \\
\hline $\mathrm{O}(3)-\mathrm{Zn}(1)-\mathrm{O}(4)$ & $85.98(8)$ \\
\hline $\mathrm{O}(3)-\mathrm{Zn}(1)-\mathrm{O}(5)$ & $88.79(8)$ \\
\hline $\mathrm{O}(3)-\mathrm{Zn}(1)-\mathrm{O}(6)$ & $102.13(8)$ \\
\hline $\mathrm{O}(4)-\mathrm{Zn}(1)-\mathrm{O}(5)$ & $173.37(8)$ \\
\hline $\mathrm{O}(4)-\mathrm{Zn}(1)-\mathrm{O}(6)$ & $90.28(8)$ \\
\hline $\mathrm{O}(5)-\mathrm{Zn}(1)-\mathrm{O}(6)$ & $86.83(8)$ \\
\hline
\end{tabular}

\begin{tabular}{|l|l|}
\hline \multicolumn{2}{|c|}{ 2b } \\
\hline \multicolumn{2}{|c|}{ Bond distance $(\AA)$} \\
\hline $\mathrm{Co}(1)-\mathrm{A}(1)$ & $2.048(3)$ \\
\hline $\mathrm{Co}(1)-\mathrm{O}(2)$ & $2.078(3)$ \\
\hline $\mathrm{Co}(1)-\mathrm{O}(3)$ & $2.085(3)$ \\
\hline $\mathrm{Co}(1)-\mathrm{O}(4)$ & $2.059(3)$ \\
\hline $\mathrm{Co}(1)-\mathrm{O}(5)$ & $2.047(3)$ \\
\hline $\mathrm{Co}(1)-\mathrm{O}(6) \quad$ Angle $\left(^{\circ}\right)$ & $2.049(3)$ \\
\hline \multicolumn{2}{|c|}{} \\
\hline $\mathrm{O}(1)-\mathrm{Co}(1)-\mathrm{O}(2)$ & $87.2(1)$ \\
\hline $\mathrm{O}(1)-\mathrm{Co}(1)-\mathrm{O}(3)$ & $90.4(1)$ \\
\hline $\mathrm{O}(1)-\mathrm{Co}(1)-\mathrm{O}(4)$ & $100.7(1)$ \\
\hline $\mathrm{O}(1)-\mathrm{Co}(1)-\mathrm{O}(5)$ & $85.7(1)$ \\
\hline $\mathrm{O}(1)-\mathrm{Co}(1)-\mathrm{O}(6)$ & $172.8(1)$ \\
\hline $\mathrm{O}(2)-\mathrm{Co}(1)-\mathrm{O}(3)$ & $174.0(1)$ \\
\hline $\mathrm{O}(2)-\mathrm{Co}(1)-\mathrm{O}(4)$ & $87.9(1)$ \\
\hline $\mathrm{O}(2)-\mathrm{Co}(1)-\mathrm{O}(5)$ & $92.9(1)$ \\
\hline $\mathrm{O}(2)-\mathrm{Co}(1)-\mathrm{O}(6)$ & $92.7(1)$ \\
\hline $\mathrm{O}(3)-\mathrm{Co}(1)-\mathrm{O}(4)$ & $87.2(1)$ \\
\hline $\mathrm{O}(3)-\mathrm{Co}(1)-\mathrm{O}(5)$ & $92.4(1)$ \\
\hline $\mathrm{O}(3)-\mathrm{Co}(1)-\mathrm{O}(6)$ & $90.4(1)$ \\
\hline $\mathrm{O}(4)-\mathrm{Co}(1)-\mathrm{O}(5)$ & $173.6(1)$ \\
\hline $\mathrm{O}(4)-\mathrm{Co}(1)-\mathrm{O}(6)$ & $86.5(1)$ \\
\hline $\mathrm{O}(5)-\mathrm{Co}(1)-\mathrm{O}(6)$ & $87.1(1)$ \\
\hline
\end{tabular}

\begin{tabular}{|l|l|}
\hline \multicolumn{2}{|c|}{ 2d } \\
\hline \multicolumn{2}{|c|}{ Bond distance $(\AA)$} \\
\hline $\mathrm{Cd}(1)-\mathrm{O}(1)$ & $2.256(3)$ \\
\hline $\mathrm{Cd}(1)-\mathrm{O}(2)$ & $2.253(3)$ \\
\hline $\mathrm{Cd}(1)-\mathrm{O}(3)$ & $2.228(2)$ \\
\hline $\mathrm{Cd}(1)-\mathrm{O}(4)$ & $2.266(2)$ \\
\hline $\mathrm{Cd}(1)-\mathrm{O}(5)$ & $2.242(2)$ \\
\hline $\mathrm{Cd}(1)-\mathrm{O}(6) \quad$ Angle $\left(^{\circ}\right)$ & $2.278(2)$ \\
\hline \multicolumn{2}{|c|}{} \\
\hline $\mathrm{O}(1)-\mathrm{Cd}(1)-\mathrm{O}(2)$ & $79.1(1)$ \\
\hline $\mathrm{O}(1)-\mathrm{Cd}(1)-\mathrm{O}(3)$ & $86.9(1)$ \\
\hline $\mathrm{O}(1)-\mathrm{Cd}(1)-\mathrm{O}(4)$ & $96.3(1)$ \\
\hline $\mathrm{O}(1)-\mathrm{Cd}(1)-\mathrm{O}(5)$ & $167.1(1)$ \\
\hline $\mathrm{O}(1)-\mathrm{Cd}(1)-\mathrm{O}(6)$ & $93.4(1)$ \\
\hline $\mathrm{O}(2)-\mathrm{Cd}(1)-\mathrm{O}(3)$ & $165.64(9)$ \\
\hline $\mathrm{O}(2)-\mathrm{Cd}(1)-\mathrm{O}(4)$ & $96.78(9)$ \\
\hline $\mathrm{O}(2)-\mathrm{Cd}(1)-\mathrm{O}(5)$ & $89.54(8)$ \\
\hline $\mathrm{O}(2)-\mathrm{Cd}(1)-\mathrm{O}(6)$ & $91.67(9)$ \\
\hline $\mathrm{O}(3)-\mathrm{Cd}(1)-\mathrm{O}(4)$ & $81.41(8)$ \\
\hline $\mathrm{O}(3)-\mathrm{Cd}(1)-\mathrm{O}(5)$ & $104.71(8)$ \\
\hline $\mathrm{O}(3)-\mathrm{Cd}(1)-\mathrm{O}(6)$ & $92.41(8)$ \\
\hline $\mathrm{O}(4)-\mathrm{Cd}(1)-\mathrm{O}(5)$ & $90.99(8)$ \\
\hline
\end{tabular}




\begin{tabular}{|l|l|}
\hline $\mathrm{O}(4)-\mathrm{Cd}(1)-\mathrm{O}(6)$ & $168.19(8)$ \\
\hline $\mathrm{O}(5)-\mathrm{Cd}(1)-\mathrm{O}(6)$ & $80.81(8)$ \\
\hline
\end{tabular}

\begin{tabular}{|l|l|}
\hline \multicolumn{2}{|c|}{ 2d' } \\
\hline \multicolumn{2}{|c|}{ Bond distance $(\AA)$} \\
\hline $\mathrm{Cd}(1)-\mathrm{O}(1)$ & $2.259(4)$ \\
\hline $\mathrm{Cd}(1)-\mathrm{O}(2)$ & $2.265(4)$ \\
\hline $\mathrm{Cd}(1)-\mathrm{O}(3)$ & $2.250(3)$ \\
\hline $\mathrm{Cd}(1)-\mathrm{O}(4)$ & $2.285(3)$ \\
\hline $\mathrm{Cd}(1)-\mathrm{O}(5)$ & $2.262(3)$ \\
\hline $\mathrm{Cd}(1)-\mathrm{O}(6)$ & $2.269(3)$ \\
\hline \multicolumn{2}{|c|}{ Angle $\left(^{\circ}\right)$} \\
\hline $\mathrm{O}(1)-\mathrm{Cd}(1)-\mathrm{O}(2)$ & $80.2(1)$ \\
\hline $\mathrm{O}(1)-\mathrm{Cd}(1)-\mathrm{O}(3)$ & $90.9(1)$ \\
\hline $\mathrm{O}(1)-\mathrm{Cd}(1)-\mathrm{O}(4)$ & $88.4(1)$ \\
\hline $\mathrm{O}(1)-\mathrm{Cd}(1)-\mathrm{O}(5)$ & $166.7(1)$ \\
\hline $\mathrm{O}(1)-\mathrm{Cd}(1)-\mathrm{O}(6)$ & $100.8(1)$ \\
\hline $\mathrm{O}(2)-\mathrm{Cd}(1)-\mathrm{O}(3)$ & $99.5(1)$ \\
\hline $\mathrm{O}(2)-\mathrm{Cd}(1)-\mathrm{O}(4)$ & $168.5(1)$ \\
\hline $\mathrm{O}(2)-\mathrm{Cd}(1)-\mathrm{O}(5)$ & $86.8(1)$ \\
\hline $\mathrm{O}(2)-\mathrm{Cd}(1)-\mathrm{O}(6)$ & $86.4(1)$ \\
\hline $\mathrm{O}(3)-\mathrm{Cd}(1)-\mathrm{O}(4)$ & $82.1(1)$ \\
\hline $\mathrm{O}(3)-\mathrm{Cd}(1)-\mathrm{O}(5)$ & $88.4(1)$ \\
\hline $\mathrm{O}(3)-\mathrm{Cd}(1)-\mathrm{O}(6)$ & $167.7(1)$ \\
\hline $\mathrm{O}(4)-\mathrm{Cd}(1)-\mathrm{O}(5)$ & $104.7(1)$ \\
\hline $\mathrm{O}(4)-\mathrm{Cd}(1)-\mathrm{O}(6)$ & $94.2(1)$ \\
\hline $\mathrm{O}(5)-\mathrm{Cd}(1)-\mathrm{O}(6)$ & $81.1(1)$ \\
\hline
\end{tabular}


Table S3: Crystallographic data for polymers 3a-b, 4b-c, 4e, 4i-l and 5b

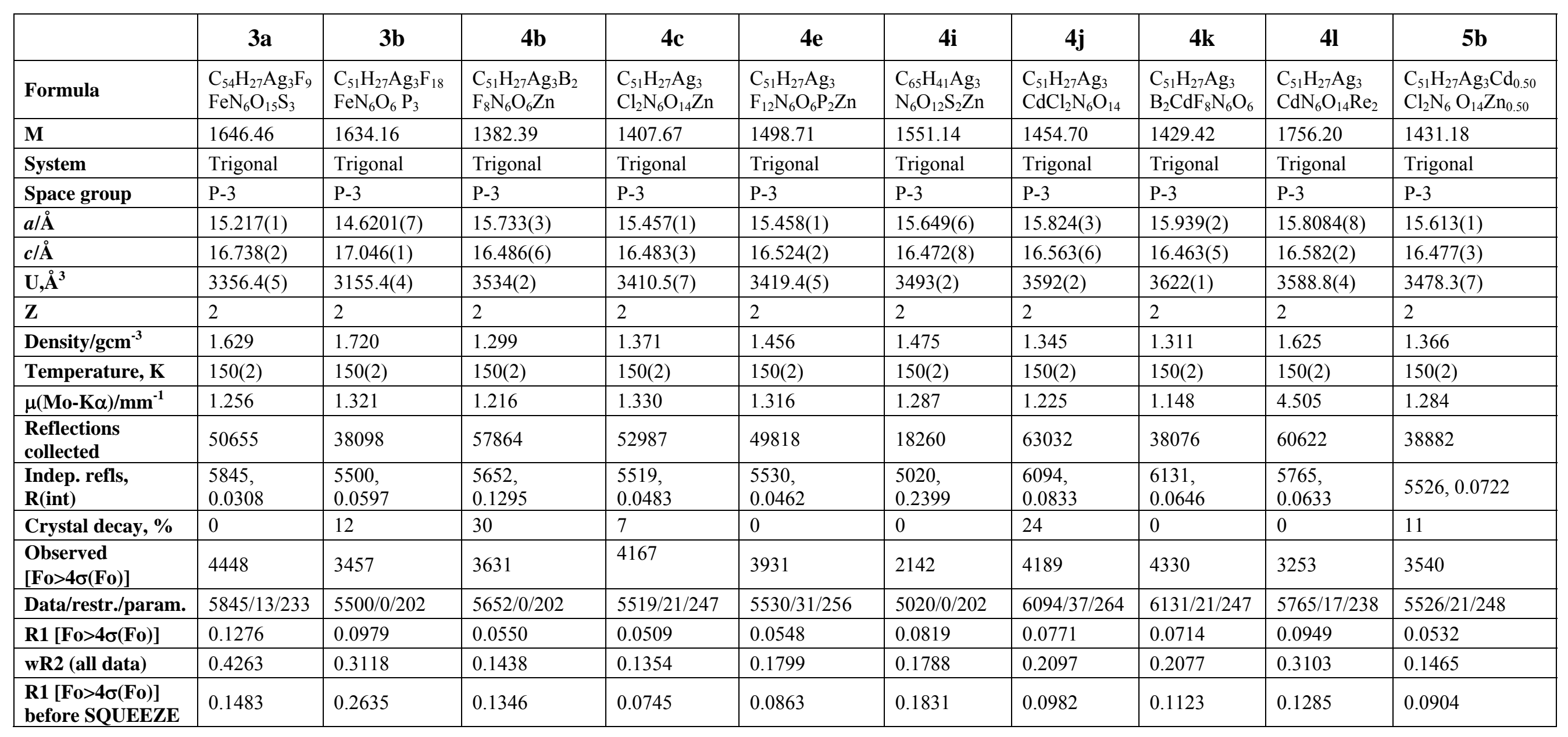


Table S4: Bond distances and angles for MOFs 3a-b, 4b-c, 4e, 4i-l and 5b.

\begin{tabular}{|l|l|}
\hline \multicolumn{2}{|c|}{ 3a } \\
\hline \multicolumn{2}{|c|}{ Bond distance $(\AA)$} \\
\hline $\mathrm{Fe}(1)-\mathrm{O}(1)$ & $1.982(4)$ \\
\hline $\mathrm{Fe}(1)-\mathrm{O}(2)$ & $1.997(4)$ \\
\hline $\mathrm{Ag}(1)-\mathrm{N}(1)$ & $2.114(7)$ \\
\hline $\mathrm{Ag}(1)-\mathrm{N}(2) \#$ & $2.141(7)$ \\
\hline $\mathrm{Ag}(1)-\mathrm{O}(12)$ & $2.45(1)$ \\
\hline \multicolumn{2}{|c|}{ Angle $\left(^{\circ}\right)$} \\
\hline $\mathrm{O}(1)-\mathrm{Fe}(1)-\mathrm{O}(1)^{*}$ & $89.1(2)$ \\
\hline $\mathrm{O}(1)-\mathrm{Fe}(1)-\mathrm{O}(2)$ & $85.4(2)$ \\
\hline $\mathrm{O}(1)-\mathrm{Fe}(1)-\mathrm{O}(2)^{*}$ & $99.0(2)$ \\
\hline $\mathrm{O}(1)-\mathrm{Fe}(1)-\mathrm{O}(2) \S$ & $170.1(2)$ \\
\hline $\mathrm{O}(2)-\mathrm{Fe}(1)-\mathrm{O}(2)^{*}$ & $87.3(2)$ \\
\hline $\mathrm{N}(1)-\mathrm{Ag}(1)-\mathrm{N}(2) \#$ & $154.3(3)$ \\
\hline $\mathrm{N}(1)-\mathrm{Ag}(1)-\mathrm{O}(12)$ & $105.5(5)$ \\
\hline $\mathrm{N}(2) \#-\mathrm{Ag}(1)-\mathrm{O}(12)$ & $94.8(4)$ \\
\hline & $\# 2-\mathrm{x}+\mathrm{y}, 2-\mathrm{x},-1+\mathrm{z} ;{ }^{*} 1-\mathrm{y}, \mathrm{x}-\mathrm{y}, \mathrm{z} ; \S 1-\mathrm{x}+\mathrm{y}, 1-\mathrm{x}, \mathrm{z}$. \\
\hline
\end{tabular}

\begin{tabular}{|l|l|}
\hline $\mathrm{N}(1) \#-A g-C(2)$ & $108.5(2)$ \\
\hline $\mathrm{N}(2) *-A g-C(2)$ & $108.8(2)$ \\
\hline
\end{tabular}

\begin{tabular}{|l|l|}
\hline \multicolumn{2}{|c|}{ 3b } \\
\hline \multicolumn{2}{|c|}{ Bond distance $(\AA)$} \\
\hline $\mathrm{Fe}(1)-\mathrm{O}(1)$ & $1.982(4)$ \\
\hline $\mathrm{Fe}(1)-\mathrm{O}(2)$ & $1.981(4)$ \\
\hline $\mathrm{Ag}(1)-\mathrm{N}(1) \#$ & $2.168(6)$ \\
\hline $\mathrm{Ag}(1)-\mathrm{N}(2) \quad$ Angle $\left(^{\circ}\right)$ \\
\hline \multicolumn{2}{|c|}{} \\
\hline $\mathrm{O}(1)-\mathrm{Fe}(1)-\mathrm{O}(1)^{*}$ & $88.0(2)$ \\
\hline $\mathrm{O}(1)-\mathrm{Fe}(1)-\mathrm{O}(2)$ & $85.3(2)$ \\
\hline $\mathrm{O}(1)-\mathrm{Fe}(1)-\mathrm{O}(2)^{*}$ & $168.7(2)$ \\
\hline $\mathrm{O}(1)-\mathrm{Fe}(1)-\mathrm{O}(2) \S$ & $100.9(2)$ \\
\hline $\mathrm{O}(2)-\mathrm{Fe}(1)-\mathrm{O}(2) \S$ & $86.9(2)$ \\
\hline $\mathrm{N}(1) \#-\mathrm{Ag}(1)-\mathrm{N}(2)$ & $146.7(3)$ \\
\hline$\# 1-\mathrm{x}+\mathrm{y}, 1-\mathrm{x}, 1+\mathrm{z} ;{ }^{*} 1-\mathrm{y}, 1+\mathrm{x}-\mathrm{y}, \mathrm{z} ; \S-\mathrm{x}+\mathrm{y}, 1-\mathrm{x}, \mathrm{z}$ \\
\hline
\end{tabular}

\begin{tabular}{|l|l|}
\hline \multicolumn{2}{|c|}{ 4b } \\
\hline $\mathrm{Zn}(1)-\mathrm{O}(1)$ & $2.084(3)$ \\
\hline $\mathrm{Zn}(1)-\mathrm{O}(2)$ & $2.054(3)$ \\
\hline Ag-N(1)\# distance $(\AA)$ \\
\hline Ag-N(2)* & $2.190(3)$ \\
\hline Ag-C(2) & $2.195(3)$ \\
\hline \multicolumn{2}{|c|}{ Angle $\left(^{\circ}\right)$} \\
\hline $\mathrm{O}(1)-\mathrm{Zn}(1)-\mathrm{O}(1) \S$ & $87.474(4)$ \\
\hline $\mathrm{O}(1)-\mathrm{Zn}(1)-\mathrm{O}(2)$ & $86.3(1)$ \\
\hline $\mathrm{O}(1)-\mathrm{Zn}(1)-\mathrm{O}(2) \S$ & $171.2(1)$ \\
\hline $\mathrm{O}(1) \S-\mathrm{Zn}(1)-\mathrm{O}(2)$ & $98.4(1)$ \\
\hline $\mathrm{O}(2)-\mathrm{Zn}(1)-\mathrm{O}(2) \S$ & $88.8(1)$ \\
\hline $\mathrm{N}(1) \#-\mathrm{Ag}-\mathrm{N}(2)^{*}$ & $142.6(2)$ \\
\hline
\end{tabular}

\begin{tabular}{|l|l|}
\hline \multicolumn{2}{|c|}{ 4c } \\
\hline \multicolumn{2}{|c|}{ Bond distance $(\AA)$} \\
\hline $\mathrm{Zn}(1)-\mathrm{O}(1)$ & $2.075(2)$ \\
\hline $\mathrm{Zn}(1)-\mathrm{O}(2)$ & $2.037(2)$ \\
\hline $\mathrm{Ag}(1)-\mathrm{N}(1) \#$ & $2.185(4)$ \\
\hline $\mathrm{Ag}(1)-\mathrm{N}(2)^{*}$ & $2.206(3)$ \\
\hline $\mathrm{Ag}(1)-\mathrm{C}(2)$ & $2.467(4)$ \\
\hline $\mathrm{Ag}(1)-\mathrm{O}(11)$ & $2.667(7)$ \\
\hline \multicolumn{2}{|c|}{ Angle $\left(^{\circ}\right)$} \\
\hline $\mathrm{O}(1)-\mathrm{Zn}(1)-\mathrm{O}(1) \S$ & $87.5(1)$ \\
\hline $\mathrm{O}(1)-\mathrm{Zn}(1)-\mathrm{O}(2)$ & $86.2(1)$ \\
\hline $\mathrm{O}(1)-\mathrm{Zn}(1)-\mathrm{O}(2) \S$ & $170.9(1)$ \\
\hline $\mathrm{O}(1) \S-\mathrm{Zn}(1)-\mathrm{O}(2)$ & $98.8(1)$ \\
\hline $\mathrm{O}(2)-\mathrm{Zn}(1)-\mathrm{O}(2) \S$ & $88.3(1)$ \\
\hline $\mathrm{N}(1) \#-\mathrm{Ag}(1)-\mathrm{N}(2)^{*}$ & $140.8(2)$ \\
\hline $\mathrm{N}(1) \#-\mathrm{Ag}(1)-\mathrm{C}(2)$ & $110.9(1)$ \\
\hline $\mathrm{N}(2)^{*}-\mathrm{Ag}(1)-\mathrm{C}(2)$ & $108.3(1)$ \\
\hline $\mathrm{N}(1) \#-\mathrm{Ag}(1)-\mathrm{O}(11)$ & $84.7(2)$ \\
\hline $\mathrm{N}(2)^{*}-\mathrm{Ag}(1)-\mathrm{O}(11)$ & $87.6(2)$ \\
\hline $\mathrm{C}(2)-\mathrm{Ag}(1)-\mathrm{O}(11)$ & $99.5(2)$ \\
\hline \# 2-x,1-y,1-z; * y,1-x+y,-z; $\S 1-\mathrm{y}, \mathrm{x}-\mathrm{y}, \mathrm{z}$ \\
\hline
\end{tabular}

\begin{tabular}{|l|l|}
\hline \multicolumn{2}{|c|}{ 4e } \\
\hline \multicolumn{2}{|c|}{ Bond distance $(\AA)$} \\
\hline $\mathrm{Zn}(1)-\mathrm{O}(1)$ & $2.066(2)$ \\
\hline $\mathrm{Zn}(1)-\mathrm{O}(2)$ & $2.042(3)$ \\
\hline $\mathrm{Ag}(1)-\mathrm{N}(1) \#$ & $2.186(4)$ \\
\hline $\mathrm{Ag}(1)-\mathrm{N}(2)^{*}$ & $2.191(4)$ \\
\hline $\mathrm{Ag}(1)-\mathrm{C}(2)$ & $2.478(4)$ \\
\hline \multicolumn{2}{|c|}{ Angle ( $)$} \\
\hline $\mathrm{O}(1)-\mathrm{Zn}(1)-\mathrm{O}(1) \S$ & $87.0(1)$ \\
\hline $\mathrm{O}(1)-\mathrm{Zn}(1)-\mathrm{O}(2)$ & $86.3(1)$ \\
\hline $\mathrm{O}(1) \S-\mathrm{Zn}(1)-\mathrm{O}(2)$ & $99.8(1)$ \\
\hline $\mathrm{O}(1)-\mathrm{Zn}(1)-\mathrm{O}(2) \S$ & $170.2(1)$ \\
\hline $\mathrm{O}(2)-\mathrm{Zn}(1)-\mathrm{O}(2) \S$ & $87.7(1)$ \\
\hline $\mathrm{N}(1) \#-\mathrm{Ag}(1)-\mathrm{N}(2)^{*}$ & $141.4(2)$ \\
\hline $\mathrm{N}(1) \#-\mathrm{Ag}(1)-\mathrm{C}(2)$ & $107.9(2)$ \\
\hline $\mathrm{N}(2) *-\mathrm{Ag}(1)-\mathrm{C}(2)$ & $110.5(2)$ \\
\hline$\# 1-\mathrm{x}, 1-\mathrm{y},-\mathrm{z} ;{ }^{*} \mathrm{y},-\mathrm{x}+\mathrm{y},-1-\mathrm{z} ; \S 1-\mathrm{y}, \mathrm{x}-\mathrm{y}, \mathrm{z}$. \\
\hline
\end{tabular}




\begin{tabular}{|l|l|}
\hline \multicolumn{2}{|c|}{ Bond distance $(\AA)$} \\
\hline $\mathrm{Zn}(1)-\mathrm{O}(1)$ & $2.052(5)$ \\
\hline $\mathrm{Zn}(1)-\mathrm{O}(2)$ & $2.080(5)$ \\
\hline $\mathrm{Ag}(1)-\mathrm{N}(2) \#$ & $2.208(8)$ \\
\hline $\mathrm{Ag}(1)-\mathrm{N}(1)^{*}$ & $2.194(7)$ \\
\hline $\mathrm{Ag}(1)-\mathrm{C}(2) \quad$ Angle $\left(^{\circ}\right)$ \\
\hline \multicolumn{2}{|c|}{} \\
\hline $\mathrm{O}(1)-\mathrm{Zn}(1)-\mathrm{O}(1) \S$ & $87.9(2)$ \\
\hline $\mathrm{O}(1)-\mathrm{Zn}(1)-\mathrm{O}(2)$ & $87.1(2)$ \\
\hline $\mathrm{O}(1)-\mathrm{Zn}(1)-\mathrm{O}(2) \S$ & $170.6(2)$ \\
\hline $\mathrm{O}(1) \S-\mathrm{Zn}(1)-\mathrm{O}(2)$ & $99.9(2)$ \\
\hline $\mathrm{O}(2)-\mathrm{Zn}(1)-\mathrm{O}(2) \S$ & $85.9(2)$ \\
\hline $\mathrm{N}(1) *-\mathrm{Ag}(1)-\mathrm{N}(2) \#$ & $141.1(3)$ \\
\hline $\mathrm{N}(1) *-\mathrm{Ag}(1)-\mathrm{C}(2)$ & $108.9(3)$ \\
\hline $\mathrm{N}(2) \#-\mathrm{Ag}(1)-\mathrm{C}(2)$ & $110.0(3)$ \\
\hline
\end{tabular}

\# 1-x,-y,2-z; * x-y,x,1-z; \& 1-y,x-y,z

\begin{tabular}{|l|l|}
\hline \multicolumn{2}{|c|}{$\mathbf{j}$} \\
\hline \multicolumn{2}{|c|}{ Bond distance $(\AA)$} \\
\hline $\mathrm{Cd}(1)-\mathrm{O}(1)$ & $2.262(4)$ \\
\hline $\mathrm{Cd}(1)-\mathrm{O}(2)$ & $2.227(4)$ \\
\hline $\mathrm{Ag}(1)-\mathrm{N}(1) \#$ & $2.189(6)$ \\
\hline $\mathrm{Ag}(1)-\mathrm{N}(2)^{*}$ & $2.197(6)$ \\
\hline $\mathrm{Ag}(1)-\mathrm{C}(2) \quad$ Angle $\left(^{\circ}\right)$ & $2.531(7)$ \\
\hline \multicolumn{2}{|c|}{} \\
\hline $\mathrm{O}(1)-\mathrm{Cd}(1)-\mathrm{O}(1) \S$ & $89.3(2)$ \\
\hline $\mathrm{O}(1)-\mathrm{Cd}(1)-\mathrm{O}(2)$ & $80.1(2)$ \\
\hline $\mathrm{O}(1) \S-\mathrm{Cd}(1)-\mathrm{O}(2)$ & $102.2(2)$ \\
\hline $\mathrm{O}(1)-\mathrm{Cd}(1)-\mathrm{O}(2) \S$ & $164.2(2)$ \\
\hline $\mathrm{O}(2)-\mathrm{Cd}(1)-\mathrm{O}(2) \S$ & $90.6(2)$ \\
\hline $\mathrm{N}(1) \#-\mathrm{Ag}(1)-\mathrm{N}(2)^{*}$ & $145.7(3)$ \\
\hline $\mathrm{N}(1) \#-\mathrm{Ag}(1)-\mathrm{C}(2)$ & $107.2(2)$ \\
\hline $\mathrm{N}(2) *-\mathrm{Ag}(1)-\mathrm{C}(2)$ & $106.7(2)$ \\
\hline
\end{tabular}

\# 1-x,1-y,1-z; * y,1-x+y,-z; § 1-y,1+x-y,z

\begin{tabular}{|l|l|}
\hline \multicolumn{2}{|c|}{$\mathbf{4 k}$} \\
\hline \multicolumn{2}{|c|}{ Bond distance $(\AA)$} \\
\hline $\mathrm{Cd}(1)-\mathrm{O}(1)$ & $2.226(4)$ \\
\hline $\mathrm{Ag}(1)-\mathrm{O}(2)-\mathrm{N}(2) \#$ & $2.267(4)$ \\
\hline $\mathrm{Ag}(1)-\mathrm{N}(1)^{*}$ & $2.195(5)$ \\
\hline $\mathrm{Ag}(1)-\mathrm{C}(2)$ & $2.202(5)$ \\
\hline \multicolumn{2}{|c|}{ Angle $\left(^{\circ}\right)$} \\
\hline $\mathrm{O}(1)-\mathrm{Cd}(1)-\mathrm{O}(1) \S$ & $2.514(6)$ \\
\hline $\mathrm{O}(1)-\mathrm{Cd}(1)-\mathrm{O}(2)$ & $91.9(1)$ \\
\hline $\mathrm{O}(1)-\mathrm{Cd}(1)-\mathrm{O}(2) \S$ & $79.7(1)$ \\
\hline $\mathrm{O}(1) \S-\mathrm{Cd}(1)-\mathrm{O}(2)$ & $164.3(2)$ \\
\hline $\mathrm{O}(2)-\mathrm{Cd}(1)-\mathrm{O}(2) \S$ & $101.6(2)$ \\
\hline
\end{tabular}

\begin{tabular}{|l|l|}
\hline $\mathrm{N}(1) *-\operatorname{Ag}(1)-\mathrm{N}(2) \#$ & $144.4(2)$ \\
\hline $\mathrm{N}(1) *-\operatorname{Ag}(1)-\mathrm{C}(2)$ & $108.4(2)$ \\
\hline $\mathrm{N}(2) \#-\operatorname{Ag}(1)-\mathrm{C}(2)$ & $107.0(2)$ \\
\hline$\# 2-\mathrm{x}, 1-\mathrm{y}, 1-\mathrm{z} ;{ }^{*} \mathrm{x}-\mathrm{y},-1+\mathrm{x}, 2-\mathrm{z} ; \quad \S 1-\mathrm{y}, \mathrm{x}-\mathrm{y}, \mathrm{z}$. \\
\hline
\end{tabular}

\begin{tabular}{|l|l|}
\hline \multicolumn{2}{|c|}{ 4l } \\
\hline \multicolumn{2}{|c|}{ Bond distance $(\AA)$} \\
\hline $\mathrm{Cd}(1)-\mathrm{O}(1)$ & $2.251(6)$ \\
\hline $\mathrm{Cd}(1)-\mathrm{O}(2)$ & $2.225(5)$ \\
\hline $\mathrm{Ag}(1)-\mathrm{N}(1) \#$ & $2.191(8)$ \\
\hline $\mathrm{Ag}(1)-\mathrm{N}(2) *$ & $2.217(7)$ \\
\hline $\mathrm{Ag}(1)-\mathrm{C}(2)$ & $2.490(9)$ \\
\hline $\mathrm{Ag}(1)-\mathrm{O}(12) \quad 2.43(1)$ \\
\hline \multicolumn{2}{|c|}{ Angle $\left(^{\circ}\right)$} \\
\hline $\mathrm{O}(1)-\mathrm{Cd}(1)-\mathrm{O}(1) \S$ & $89.3(2)$ \\
\hline $\mathrm{O}(1)-\mathrm{Cd}(1)-\mathrm{O}(2)$ & $79.4(2)$ \\
\hline $\mathrm{O}(1)-\mathrm{Cd}(1)-\mathrm{O}(2) \S$ & $164.3(2)$ \\
\hline $\mathrm{O}(1) \S-\mathrm{Cd}(1)-\mathrm{O}(2)$ & $101.4(2)$ \\
\hline $\mathrm{O}(2)-\mathrm{Cd}(1)-\mathrm{O}(2) \S$ & $92.0(2)$ \\
\hline $\mathrm{N}(1) \#-\mathrm{Ag}(1)-\mathrm{N}(2) *$ & $142.8(3)$ \\
\hline $\mathrm{N}(1) \#-\mathrm{Ag}(1)-\mathrm{C}(2)$ & $109.7(3)$ \\
\hline $\mathrm{N}(2)^{*}-\mathrm{Ag}(1)-\mathrm{C}(2)$ & $107.0(3)$ \\
\hline \# 2-x,1-y,-z; ${ }^{*} \mathrm{y}, 1-\mathrm{x}+\mathrm{y}, 1-\mathrm{z} ; \S 1-\mathrm{y}, \mathrm{x}-\mathrm{y}, \mathrm{z}$. \\
\hline
\end{tabular}

\begin{tabular}{|c|c|}
\hline \multicolumn{2}{|c|}{$5 b$} \\
\hline \multicolumn{2}{|c|}{ Bond distance $(\AA)^{\mathrm{a}}$} \\
\hline $\mathrm{M}-\mathrm{O}(1)$ & $2.111(3)$ \\
\hline $\mathrm{M}-\mathrm{O}(2)$ & $2.160(3)$ \\
\hline $\operatorname{Ag}(1)-\mathrm{N}(1) \#$ & $2.195(4)$ \\
\hline $\operatorname{Ag}(1)-\mathrm{N}(2) *$ & $2.205(4)$ \\
\hline $\operatorname{Ag}(1)-C(2)$ & $2.473(5)$ \\
\hline $\operatorname{Ag}(1)-\mathrm{O}(11)$ & $2.669(9)$ \\
\hline \multicolumn{2}{|c|}{ Angle $\left(^{\circ}\right)^{\mathrm{a}}$} \\
\hline $\mathrm{O}(1)-\mathrm{M}-\mathrm{O}(1) \S$ & $89.8(1)$ \\
\hline $\mathrm{O}(1)-\mathrm{M}-\mathrm{O}(2)$ & $83.2(1)$ \\
\hline $\mathrm{O}(1)-\mathrm{M}-\mathrm{O}(2) \S$ & $167.6(1)$ \\
\hline $\mathrm{O}(1) \S-\mathrm{M}-\mathrm{O}(2)$ & $100.3(1)$ \\
\hline $\mathrm{O}(2)-\mathrm{M}-\mathrm{O}(2) \S$ & $88.1(1)$ \\
\hline $\mathrm{N}(1) \#-\operatorname{Ag}(1)-\mathrm{N}(2)^{*}$ & $140.9(2)$ \\
\hline $\mathrm{N}(1) \#-\operatorname{Ag}(1)-\mathrm{C}(2)$ & $110.3(2)$ \\
\hline $\mathrm{N}(2) *-\operatorname{Ag}(1)-\mathrm{C}(2)$ & $108.8(2)$ \\
\hline
\end{tabular}


TABLE S5 : Cell parameters for other members of the $\mathbf{3}$ and $\mathbf{4}$ families (from single crystal X-ray measures), all

belonging to the trigonal space group P-3 (No. 147)

\begin{tabular}{llllcc}
\hline & \multicolumn{1}{c}{ Compound } & \multicolumn{1}{c}{$\boldsymbol{a} / \mathbf{A}$} & \multicolumn{1}{c}{$\boldsymbol{c} / \mathbf{\AA}$} & \multicolumn{1}{c}{$\mathbf{U , \AA ^ { 3 }}$} & \multicolumn{1}{c}{$\mathbf{T , K}$} \\
\hline $\mathbf{3 c}$ & {$\left[\mathrm{Fe}^{\mathrm{III}} \mathbf{L}_{3} \mathrm{Ag}_{3}\right]\left(\mathrm{BF}_{4}\right)_{3}$} & $15.231(6)$ & $16.668(5)$ & $3349(3)$ & 150 \\
$\mathbf{3 d}$ & {$\left[\mathrm{Fe}^{\mathrm{III}} \mathbf{L}_{3} \mathrm{Ag}_{3}\right]\left(\mathrm{ClO}_{4}\right)_{3}$} & $15.16(1)$ & $16.56(1)$ & $3296(6)$ & 298 \\
$\mathbf{3 e}$ & {$\left[\mathrm{Co}^{\mathrm{III}} \mathbf{L}_{3} \mathrm{Ag}_{3}\right]\left(\mathrm{SbF}_{6}\right)_{3}$} & $14.876(2)$ & $16.723(3)$ & $3205(1)$ & 150 \\
$\mathbf{3 f}$ & {$\left[\mathrm{Co}^{\mathrm{II}} \mathbf{L}_{3} \mathrm{Ag}_{3}\right]\left(\mathrm{CF}_{3} \mathrm{SO}_{3}\right)_{3}$} & $15.09(1)$ & $16.96(1)$ & $3259(5)$ & 150 \\
$\mathbf{3 g}$ & {$\left[\mathrm{Co}^{\mathrm{II}} \mathbf{L}_{3} \mathrm{Ag}_{3}\right]\left(\mathrm{BF}_{4}\right)_{3}$} & $15.23(1)$ & $16.73(1)$ & $3362(7)$ & 150 \\
$\mathbf{4 a}$ & {$\left[\mathrm{Mn}^{\mathrm{II}} \mathbf{L}_{3} \mathrm{Ag}_{3}\right]\left(\mathrm{BF}_{4}\right)_{2}$} & $15.577(2)$ & $16.574(2)$ & $3483(1)$ & 150 \\
$\mathbf{4 d}$ & {$\left[\mathrm{Zn}^{\mathrm{II}} \mathbf{L}_{3} \mathrm{Ag}_{3}\right]\left(\mathrm{tosilate}_{2}\right.$} & $14.982(3)$ & $16.664(6)$ & $3239(2)$ & 150 \\
$\mathbf{4 f}$ & {$\left[\mathrm{Zn}^{\mathrm{II}} \mathbf{L}_{3} \mathrm{Ag}_{3}\right]\left(\mathrm{AsF}_{6}\right)_{2}$} & $15.80(1)$ & $16.50(1)$ & $3550(5)$ & 120 \\
$\mathbf{4 g}$ & {$\left[\mathrm{Zn}^{\mathrm{II}} \mathbf{L}_{3} \mathrm{Ag}_{3}\right]\left(\mathrm{SbF}_{6}\right)_{2}$} & $15.03(1)$ & $16.88(1)$ & $3302(5)$ & 120 \\
$\mathbf{4 h}$ & {$\left[\mathrm{Zn}^{\mathrm{II}} \mathbf{L}_{3} \mathrm{Ag}_{3}\right]\left(\mathrm{NO}_{3}\right)_{2}$} & $15.27(1)$ & $16.71(1)$ & $3372(5)$ & 150 \\
$\mathbf{5 a}$ & {$\left[\mathrm{Zn}_{\mathrm{x}} \mathrm{Fe}_{\mathrm{y}} \mathbf{L}_{3} \mathrm{Ag}_{3}\right]\left(\mathrm{ClO}_{4}\right)_{(2 \mathrm{x}+3 \mathrm{y})}$} & $15.42(1)$ & $16.55(1)$ & $3409(5)$ & 150 \\
\hline
\end{tabular}

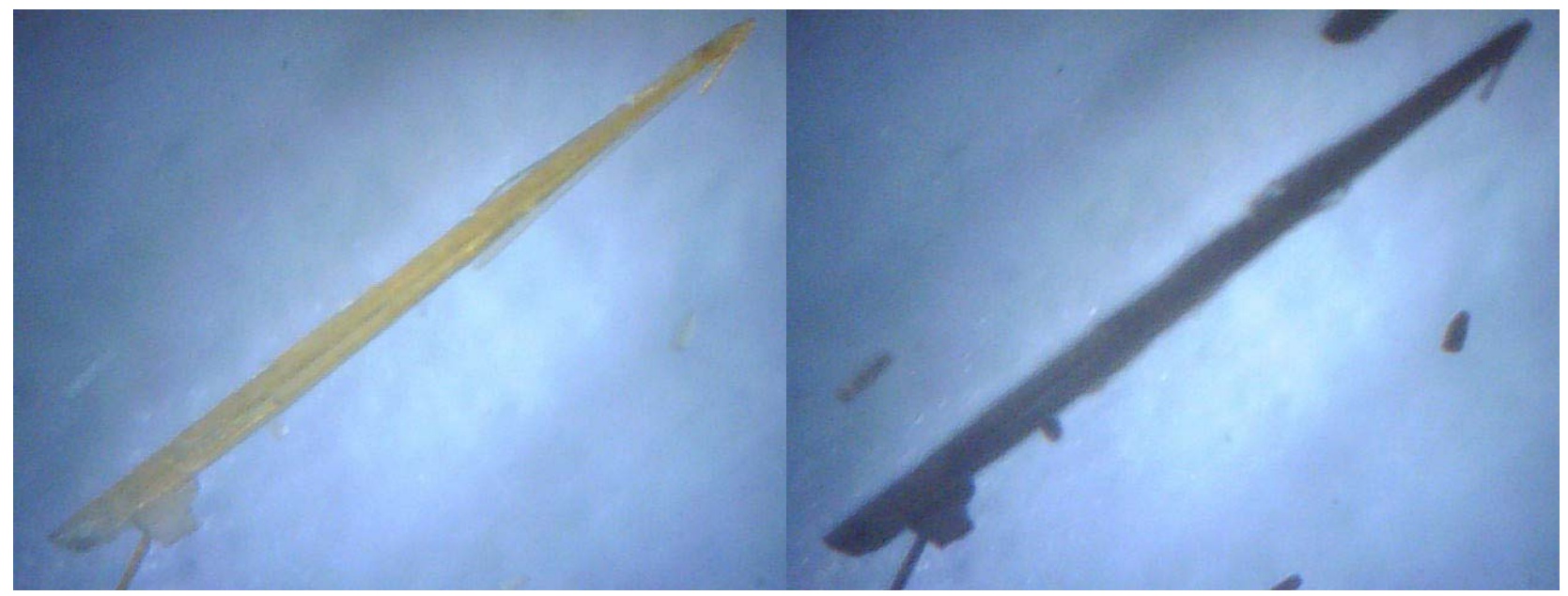

Figure $\mathrm{S} 12$ - On the left a crystal of compound $\left[\mathrm{ZnL}_{3} \mathrm{Ag}_{3}\right]\left(\mathrm{CF}_{3} \mathrm{SO}_{3}\right)_{2}$ (4d); on the right the same crystal left in a saturated methanolic solution of $\mathrm{NaClO}_{4}$ for $2.5 \mathrm{~h}$. The exposition of the crystal to the microscope light increase the deposition of metallic silver that settle on the crystal surface. 


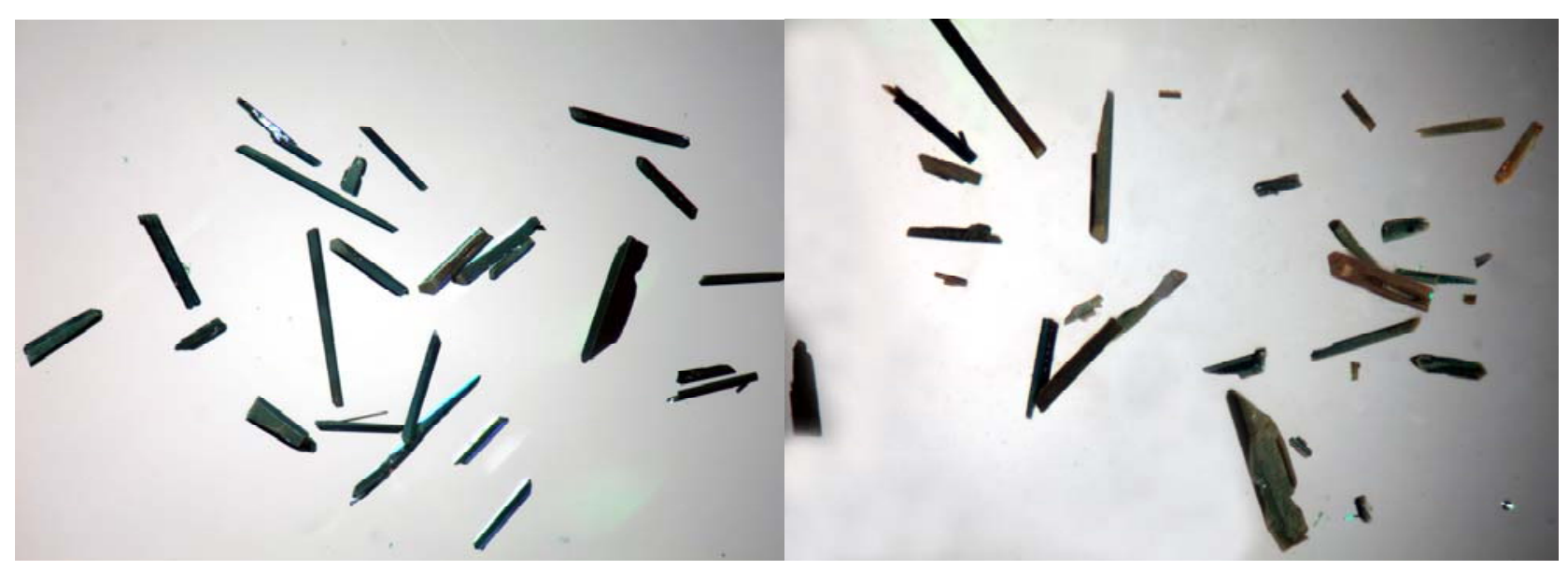

Figure S13 - On the left dried crystals of compound $\left[\mathrm{ZnL}_{3} \mathrm{Ag}_{3}\right]\left(\mathrm{BF}_{4}\right)_{2}(\mathbf{4 b})$; on the right the same crystals left in a saturated methanolic solution of $\mathrm{NaClO}_{4}$ for $3.0 \mathrm{~h}$. 